\title{
Processos de apoio ao desenvolvimento de aplicações Web
}

Osnete Ribeiro de Souza 
SERVIÇO DE PÓS GRADUAÇÃO DO ICMC-USP

Data de Depósito: 14.03.2005

Assinatura:

\section{Processos de Apoio ao Desenvolvimento de Aplicações Web}

Osnete Ribeiro de Souza

Orientadora: Profa. Dra. Rosely Sanches

Dissertação apresentada ao Instituto de Ciências Matemáticas e de Computação - ICMC USP, como parte dos requisitos para obtenção do título de Mestre em Ciências de Computação e Matemática Computacional.

USP - São Carlos

Março de 2005 


\section{AGRADECIMENTOS}

A Deus, que orienta os meus passos.

À minha orientadora, Profa. Dra. Rosely Sanches, pelo incentivo, pela confiança, pela amizade e pela compreensão. Exemplo de profissional e de mulher.

Ao meu grande amor, André Figueiredo, por fazer parte da minha vida, completá-la e aceitar a andar juntos, lado a lado, o mesmo caminho.

Aos meus pais, pelo exemplo de dedicação, amor, persistência e que me ensinou a lutar pelas conquistas e aprender com as derrotas.

Aos meus irmãos, pelo companheirismo, amizade, amor e por compartilhar as alegrias e os dissabores desta vida.

Aos meus sobrinhos, pelo amor, por alegrar os meus dias com seus sorrisos e me mostrar a felicidade nas pequenas coisas.

Aos meus amigos, pelo carinho, pelo companheirismo, e por entender a falta de tempo para as conversas.

À equipe da Lúcida, pela transparência e colaboração na definição do trabalho.

Ao CNPq, pelo apoio financeiro.

Ao ICMC e aos professores, pelo conhecimento adquirido.

A todos aqueles que contribuíram, direta e indiretamente, para a concretização do meu sonho. 


\section{RESUMO}

Num curto período de tempo, a Web tornou-se o aspecto central de muitas aplicações em diferentes áreas. Rapidamente, cresceu e diversificou seu uso, e diversos setores de negócio realizam suas operações no ambiente da Web. Entretanto, à medida que cresce a extensão de uso de aplicações Web, que se tornam mais complexas, aumenta a preocupação com a maneira como as aplicações são desenvolvidas. Freqüentemente, a abordagem de desenvolvimento é ad hoc, desprovida de técnicas sistemáticas e de metodologias sólidas, resultando em aplicações de baixa qualidade. A fim de alcançar aplicações Web bem sucedidas, há a necessidade de melhores princípios de desenvolvimento que devem considerar as características especiais dessas aplicações.

Dessa forma, o objetivo do trabalho é propor Processos de Apoio ao desenvolvimento das aplicações Web, baseando-se nas características dessas aplicações e nos Processos de Apoio da ISO/IEC 12207. Os processos de Apoio visam auxiliar outros processos do ciclo de vida da aplicação a alcançar produtos de qualidade e o sucesso do projeto. 


\section{ABSTRACT}

Within a short period, the Web has become the central aspect of many applications in different areas. Rapidly, it has grown and diversified in its scope and use. Diverse business sectors improve their operations in Web environment. The Web application has become more complex and it has increased the concern with the way the application is developed. Frequently, the development is ad hoc, unprovide of systematic methods and methodologies, resulting in poor quality applications. In order to have successful Web applications, it is necessary better principles of development that have to consider the characteristics of these applications.

The objective of this work is to propose Supporting Process for development Web applications, based on the characteristics of these applications and the Supporting Process of ISO/IEC 12207. The Supporting processes aim to assist other processes of the cycle of life of the application to reach quality products and successful projects. 


\section{ÍNDICE GERAL}

CAPÍTULO 1: INTRODUÇÃO....................................................................................................1

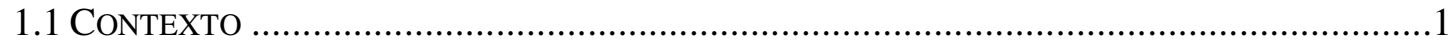

1.2 OBJETIVO

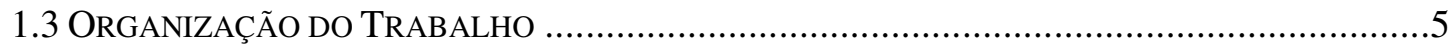

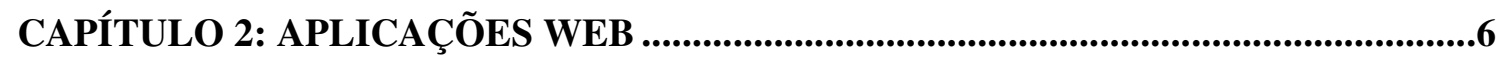

2.1 CONSIDERAÇÕES INICIAIS ……………………………………………………...

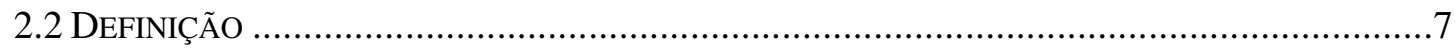

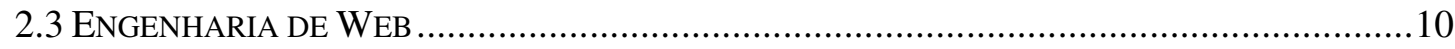

2.4 Perspectivas no DesenVolviMENTo de APLICAÇões Web ........................................12

2.4.1 Processo de Desenvolvimento .....................................................................12

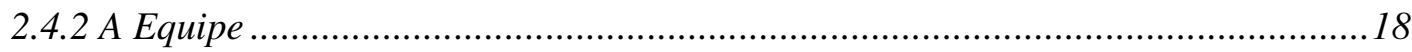

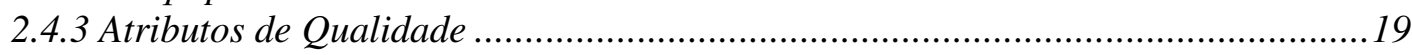

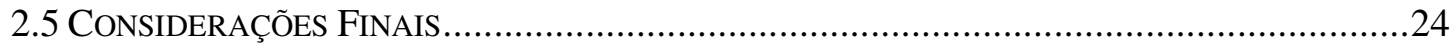

CAPÍTULO 3: ISO/IEC 12207 - PROCESSOS DO CICLO DE VIDA DO SOFTWARE

.

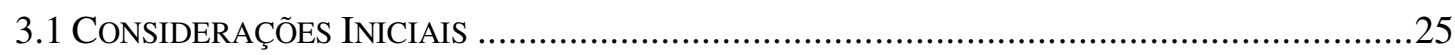

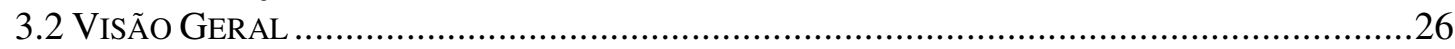

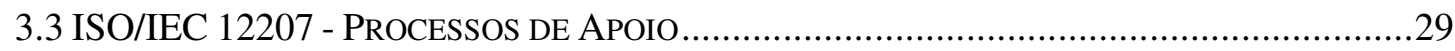

3.3.1 Documentação …………………………………….......................................29

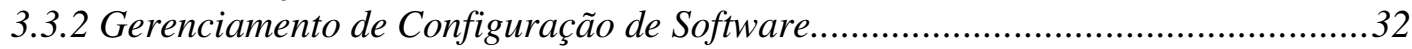

3.3.3 Garantia de Qualidade ..................................................................................36

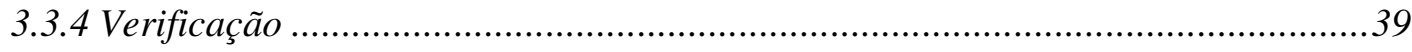

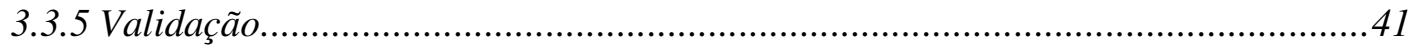

3.3.6 Revisão Conjunta ………………………………………………………....4

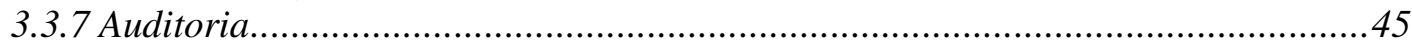

3.3.8 Resolução de Problemas ...................................................................................46

3.4 CONSIDERAÇÕES FINAIS........................................................................................

CAPÍTULO 4: PROCESSOS DE APOIO AO DESENVOLVIMENTO DE

APLICAÇÕES WEB.........................................................................................48

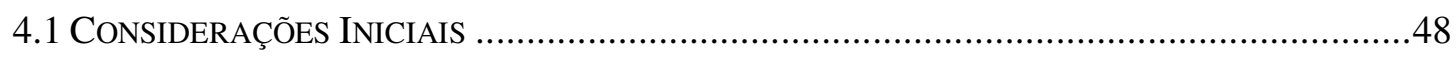

4.2 Processos de Apoio ao Desenvolvimento de AplicaÇões Web................................49

4.2.1 As Atividades dos Processos............................................................................51

4.2.2 Princípios básicos dos Processos ....................................................................53

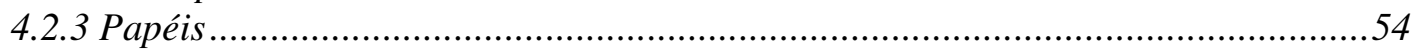

4.2.4 Garantia de Qualidade ...............................................................................56

4.2.5 Documentação ……………………………………...................................63

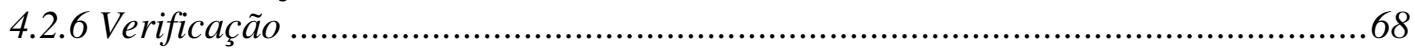

4.2.7 Validação

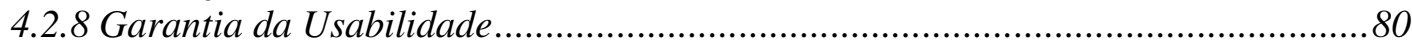

4.2.9 Gerenciamento de Configuração ........................................................................85

4.2.10 Resolução de Problemas ................................................................................99

4.2.11 Acompanhamento de Projeto.......................................................................97 


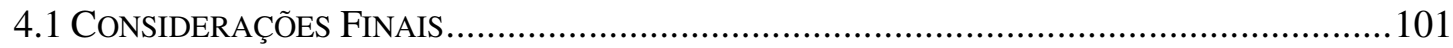

CAPÍTULO 5: APLICABILIDADE DOS PROCESSOS DE APOIO .............................102

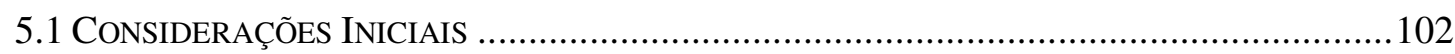

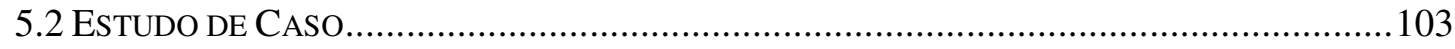

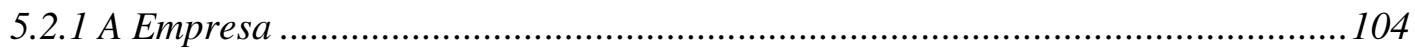

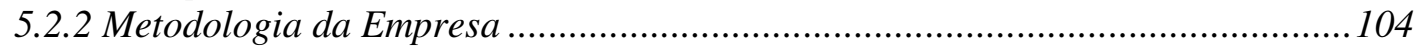

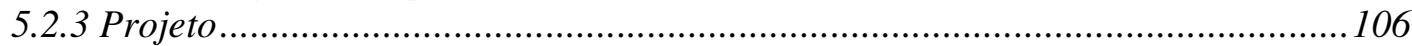

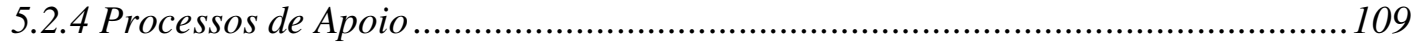

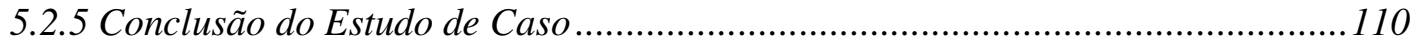

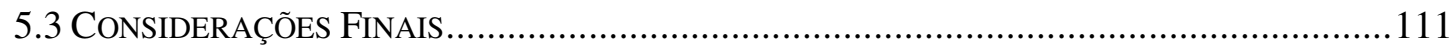

CAPÍTULO 6: CONCLUSÕES E TRABALHOS FUTUROS ...................................113

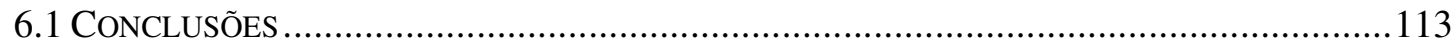

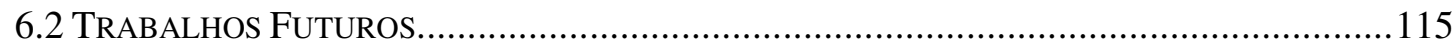

REFERÊNCIAS BIBLIOGRÁFICAS ..............................................................116 


\section{LISTA DE QUADROS}

Quadro 1: Categorias de Aplicações Web. ...........................................................................8

Quadro 2: Configuração de Software: Classes de Informação .............................................34

Quadro 3:Template de tarefas das atividades ..............................................................52

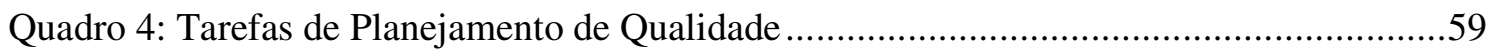

Quadro 5: Tarefas de Garantia de Produto .......................................................................61

Quadro 6: Tarefas de Garantia de Processo........................................................................63

Quadro 7: Tarefas de Planejamento da Documentação......................................................66

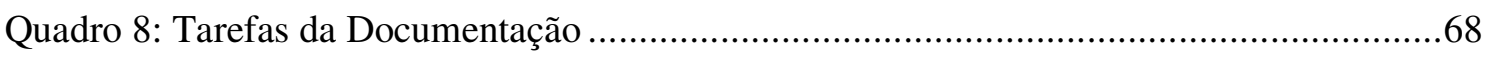

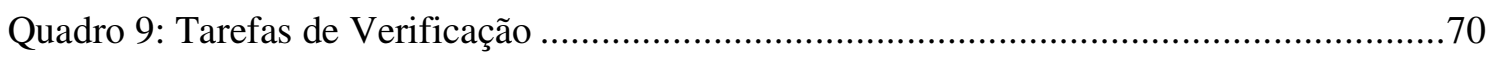

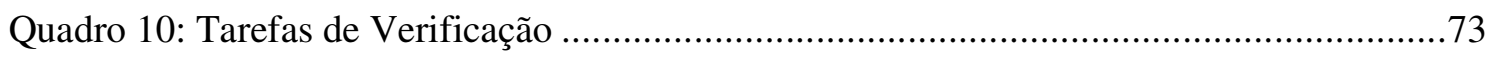

Quadro 11: Tarefas de Planejamento de Validação .........................................................76

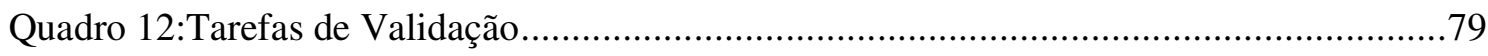

Quadro 13: Tarefas de Planejamento de Usabilidade ......................................................82

Quadro 14: Tarefas de Garantia de Usabilidade .......................................................... 84

Quadro 15: Tarefas de Planejamento de Configuração ......................................................... 88

Quadro 16: Tarefas de Identificação de Configuração.......................................................89

Quadro 17: Tarefas de Controle de Configuração .............................................................91

Quadro 18: Tarefas de Relato da Situação da Configuração ...............................................93

Quadro 19: Tarefas de Planejamento de Resolução de Problemas .......................................95

Qaudro 20: Tarefas de Resolução de Problemas................................................................97

Quadro 21: Tarefas de Planejamento de Acompanhamento de Projeto ................................99

Quadro 22: Tarefas de Acompanhamento de Projeto ..................................................... 101 


\section{LISTA DE FIGURAS}

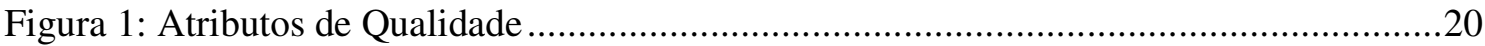

Figura 2: Processo de Engenharia de Usabilidade definido na ISO 13407 ..........................22

Figura 3: Processos do Ciclo de Vida do Software .......................................................28

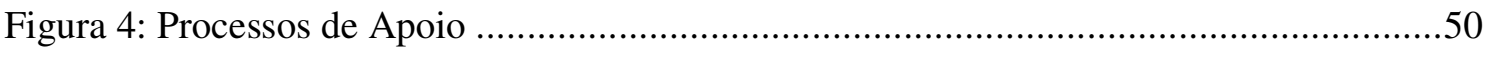

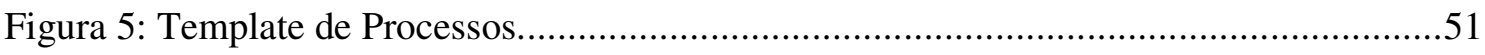

Figura 6 Template da Atividade: Artefatos de Entrada e Saída e Responsáveis....................52

Figura 7 Atividades de Garantia de Qualidade .............................................................57

Figura 8: Planejamento de Qualidade: artefatos e responsáveis.......................................57

Figura 9: Garantia do Produto: artefatos e responsáveis. ..................................................60

Figura 10: Garantia do Processo: artefatos e responsáveis..................................................62

Figura 11: Atividades de Documentação.........................................................................64

Figura 12: Planejamento de Documentação: artefatos e responsáveis.................................65

Figura 13: Produção da Documentação: artefatos e responsáveis .......................................67

Figura 14: Atividades de Verificação...........................................................................69

Figura 15: Planejamento de Verificação: artefatos e responsáveis .......................................69

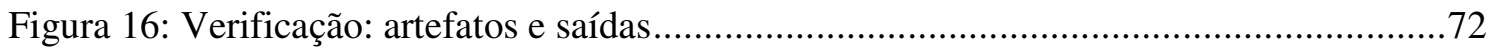

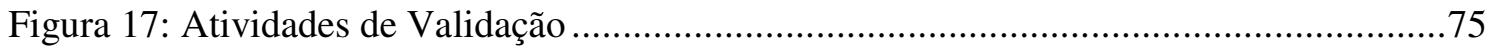

Figura 18: Planejamento de Validação: artefatos e responsáveis. .......................................75

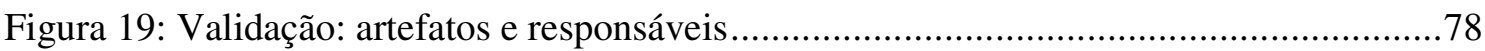

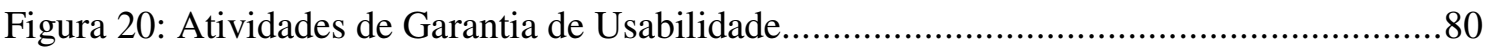

Figura 21:Planejamento de Usabilidade: artefatos e responsáveis ....................................81

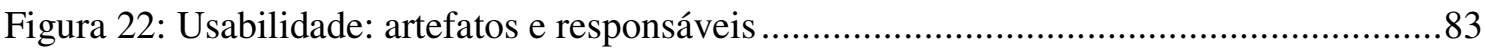

Figura 23: Atividades de Gerenciamento de Configuração................................................86

Figura 24: Planejamento de Configuração: artefatos e responsáveis ....................................87

Figura 25: Identificação de Configuração: artefatos e responsáveis.......................................88

Figura 26: Controle de Configuração: artefatos e saídas.....................................................90

Figura 27: Relato da Situação da Configuração: artefatos e responsáveis .............................92

Figura 28: Atividades de Resolução de Problema ............................................................94

Figura 29: Planejamento da Resolução de Problemas: artefatos e responsáveis ....................94

Figura 30: Resolução de Problemas: artefatos e responsáveis..........................................96 
Figura 31: Atividades de Acompanhamento de Projeto......................................................98

Figura 32: Planejamento de Acompanhamento de Projeto: artefatos e responsáveis ..............98

Figura 33: Acompanhamento de Projeto: artefatos e responsáveis .....................................100

Figura 34: Modelo de Dados da Funcionalidade Questionário............................................108 


\section{CAPÍTULO 1: INTRODUÇÃO}

\subsection{CONTEXTO}

Nos últimos anos, a World Wide Web (Web) tornou-se presente em muitas situações da vida de milhares de pessoas em todo o mundo, ultrapassando todos os outros desenvolvimentos tecnológicos da história [Ginige \& Murugesan, 2001a]. Rapidamente, cresceu e diversificou seu uso, afetando significativamente diversos aspectos da vida cotidiana.

O extraordinário crescimento da Internet e da Web teve um impacto significante nos negócios, comércio, indústria, banco, finanças, educação, governo, setores de entretenimento, na vida pessoal e profissional. A Web tornou-se o aspecto central de muitas aplicações em diferentes áreas. Hoje, diversos setores de negócio realizam suas operações no ambiente da Internet, muitos sistemas de informação legados e de banco de dados estão migrando para os ambientes de Internet. Uma vasta abrangência de novos e complexos sistemas comerciais e corporativos está emergindo no ambiente de Web [Li et al, 2000].

Dois fatores principais contribuíram para a expansão do uso da Web como base para a solução de diversas necessidades. O primeiro é a percepção das vantagens alcançadas com a Web como um meio de negócio. A Web permite novas possibilidades de criação de produtos, de comunicação e de diminuição de custos. O segundo fator é o surgimento de novas e variadas tecnologias e ferramentas para o desenvolvimento e emprego das aplicações 
[Chaubey \& Suresh, 2001], com destaque para as tecnologias de segurança que permitiram aplicações mais confiáveis.

A Web como um paradigma da computação introduziu fundamentalmente novas possibilidades para a criação, direção e diferenciação nos domínios de negócio [Chaubey \& Suresh, 2001]. Devido aos grandes benefícios da Web, em qualquer tempo em qualquer lugar [Chung \& Lee, 2002], atualmente, a Web é extensivamente usada como principal meio de comunicação com o mundo externo, assim como, dentro de uma organização e também como ferramenta para execução dos processos de uma maneira mais efetiva. Web sites que simplesmente exibiam informações para os visitantes tornaram-se sistemas interativos e altamente funcionais que permitem que muitos e variados tipos de usuários interajam com muitos e diferentes tipos de aplicações [Offutt, 2002].

Com isso, o desenvolvimento de aplicações no contexto da Internet é essencialmente caracterizado pela necessidade da otimização do tempo num ambiente onde a competição depende de quão rápido se atende às necessidades do usuário e da integração de todos os aspectos de negócio [Gilder, 1998]. Isso significa evolução contínua e rápida da aplicação e resolução imediata de problemas. Aplicações Web são sistemas vivos [Ginige \& Murugesan, 2001a]. Suas funcionalidades e conteúdos mudam e crescem rapidamente durante o ciclo de vida, muito mais do que normalmente se encontra nos sistemas tradicionais. Esses dois fatores - mudança contínua e imediatismo - são características centrais dessas aplicações.

Além disso, as aplicações Web suportam um conjunto complexo de informações e funcionalidades, são implementadas em múltiplas linguagens e estilos, incorporam reuso de diversos componentes, e realizam intensamente interação com usuários, outras aplicações e bases de dados e empregam uma equipe de desenvolvimento com habilidades das mais variadas áreas [Offutt, 2002].

Por essas razões, um grande número de livros, artigos e conferências defendem que a visão dos processos de desenvolvimento Web é diferente dos sistemas tradicionais: requer novos métodos, novas ferramentas, novos papéis e novas práticas de trabalho:

"Desenvolvimento de sistemas Web é significantemente diferente do desenvolvimento de software tradicional e propõe muitos desafios adicionais. Existem diferenças sutis na 
natureza e no ciclo de vida de sistemas e softwares baseados na Web e na maneira pela qual eles são desenvolvidos e mantidos.” [Ginige \& Murugesan, 2001a].

Por outro lado, apesar da Web ser uma nova tecnologia, as "velhas" virtudes e métodos da Engenharia de Software e desenvolvimento de sistemas continuam necessários e aplicáveis [Holck, 2003]. A construção de uma aplicação Web é um processo de muitos passos que são interativos e que influenciam um ao outro. Dessa forma, para entregar aplicações Web com alta qualidade dentro do limite de tempo e custo, desenvolvedores devem seguir um processo de desenvolvimento sistemático, possivelmente apoiado por ferramentas adequadas e metodologias sólidas [Coda et al, 1998]. Os benefícios de um processo de software bem definido são bem conhecidos [Ghezzi, 1997], assim como, sabe-se que a qualidade dos produtos de software está fortemente relacionada à qualidade do processo de software [Fuggetta, 2000]. Dessa forma, abordagens importantes como a ISO/IEC 12207 [ISO/IEC 12207,1995] sugerem que melhorando o processo de desenvolvimento, pode-se melhorar a qualidade dos produtos de software [Pfleeger, 1998].

A ISO/IEC 12207 consiste de um conjunto bem definido de processos, atividades e tarefas que são aplicados para a aquisição, fornecimento, desenvolvimento e manutenção do software e cobre todo o ciclo de vida de software. Os processos podem ser adaptados de acordo com as características dos projetos de software e são agrupados nas seguintes categorias: processos fundamentais, que iniciam e executam o desenvolvimento, operação e manutenção dos produtos de software; processos organizacionais, que estabelecem e implementam uma estrutura constituída dos processos de ciclo de vida e pelo pessoal envolvido no desenvolvimento de software; processos de apoio, que têm como objetivo auxiliar outros processos, visando principalmente a qualidade e o sucesso do projeto.

A ISO/IEC 12207 é usada como referência em muitos países. Tem como objetivo principal fornecer uma arquitetura consistente para que os profissionais envolvidos com a produção de software utilizem uma linguagem comum, auxiliando-os a definir os seus papéis e assim proporcionar às organizações um meio de alcançar produtos de software com melhor produtividade e qualidade. 


\subsection{OBJETIVO}

A qualidade das aplicações Web é um fator de grande preocupação, pois à medida que aumenta o uso e a diversificação das aplicações Web, elas tornam-se mais complexas. [Murugesan \& Deshpande, 2002]. Com a evolução, aumentou significativamente a complexidade do projeto, desenvolvimento, manutenção e gerenciamento desses sistemas.

A fim de alcançar aplicações Web bem sucedidas e com qualidade, uma estrutura sólida deve ser estabelecida para suportar o crescimento de uma aplicação Web de uma maneira controlada, porém, flexível e consistente. Há uma crescente necessidade de bons princípios de gerenciamento, utilizando-se de abordagens disciplinadas, métodos e ferramentas adequados, que considerem as características especiais dessas aplicações, assim como o meio, o ambiente e os cenários operacionais [Pressman, 2002].

$\mathrm{Na}$ literatura, está crescendo a publicação de estudos sobre processos de desenvolvimento de aplicações Web, para atender as características especiais dessas aplicações. Porém, há ainda uma carência de estudo sobre Processos de Apoio - sendo esses compostos, de acordo com a Norma ISO/IEC 12207, pelos processos de Documentação, Gerenciamento de Configuração, Garantia de Qualidade, Verificação, Validação, Revisão Conjunta, Resolução de Problema e Auditoria, que visam auxiliar na produção dessas aplicações.

Dessa forma, o propósito principal deste trabalho é propor Processos de Apoio ao desenvolvimento das aplicações Web, adaptados à natureza dessas aplicações e tomando como base os aspectos observados na literatura sobre as características dessas aplicações e nos Processos de Apoio da Norma Internacional ISO/IEC 12207. 


\subsection{ORGANIZAÇÃO DO TRABALHO}

A organização deste documento apresenta-se conforme segue.

No Capítulo 2 - Aplicações de Web são descritas as características principais das aplicações Web. No capítulo seguinte, Capítulo 3 - Norma ISO/IEC 12207 - Processos de Ciclo de Vida do Software, apresenta-se uma visão geral da Norma e uma descrição mais detalhada dos Processos de Apoio que a compõem.

O trabalho desenvolvido é apresentado no capítulo seguinte, Capítulo 4 - Processos de Apoio ao desenvolvimento de aplicações Web. E no Capítulo 5 - Aplicabilidade dos Processos de Apoio é apresentado um estudo de caso. Por fim, os capítulos de Conclusão e Referências Bibliográficas encerram o documento. 


\section{CAPÍtulo 2: Aplicações Web}

\section{1 CONSIDERAÇÕES INICIAIS}

Originalmente, a Web foi concebida com o propósito de compartilhar informações científicas entre poucos pesquisadores [Ginige \& Murugesan, 2001a]. Atualmente, o seu uso é muito diferente. Pode-se comprar ações, passagens aéreas, suprimentos, fazer transações bancárias, reservas de hotel, pesquisa, conhecer pessoas e outras atividades.

As aplicações Web tornaram-se complexas e o seu desenvolvimento abrange os conhecimentos de diversas disciplinas [Ginige \& Murugesan, 2001a, 2001b; Deshpande \& Hansen, 2001], sendo diferentes de muitas outras categorias de software.

Dessa forma, neste capítulo são apresentadas as características principais das aplicações Web que justificam abordagens de desenvolvimento mais direcionadas para essas aplicações. 


\subsection{DEFINIÇÃO}

As aplicações Web produzem uma complexa combinação de conteúdos e funcionalidades para uma ampla população de usuários [Pressman, 2002]. Segundo Powell [1998] "envolvem uma mistura entre publicação impressa e desenvolvimento de software, entre marketing e computação, comunicações internas e relações externas, e entre arte e tecnologia".

Aplicações Web são compostas de páginas Web com as quaisos usuários interagem através de browsers $^{l}$. As páginas Web são ligadas com muitas outras páginas ou aplicações externas através de links. Uma página Web é definida como a composição de objetos. Um objeto pode ser um link, um botão de comando, uma mensagem, uma imagem, um arquivo, áudio ou uma aplicação. Dessa forma, uma aplicação Web é definida em termos de páginas Web que por sua vez são definidas recursivamente em termos de objetos.

De maneira geral, as aplicações Web podem ser descritas como um híbrido de hipermídia [Nielsen, 1995] e sistemas de informação. Como na hipermídia, a informação é acessada de uma maneira mais exploratória do que através de interfaces direcionadas, e a maneira pela qual ela é navegada e apresentada é de grande importância. Similar aos sistemas de informação, o tamanho e a volatilidade dos dados e a distribuição das aplicações requerem soluções arquiteturais consolidadas baseadas em tecnologias como as de gerenciamento de banco de dados e de computação cliente-servidor [Fratenali, 1999].

Podem ser agrupadas em sete categorias [Ginige \& Murugesan, 2001a], como é mostrado no Quadro 1, embora uma determinada aplicação possa pertencer a mais de uma categoria.

\footnotetext{
${ }^{1}$ Browsers são aplicações usadas para navegação em hipertexto.
} 
Quadro 1: Categorias de Aplicações Web.

\begin{tabular}{clc}
\hline Categoria & \multicolumn{1}{c}{ Exemplos } \\
\hline Informativo & Jornais Online, catálogos de produto, manuais de \\
& serviços, classificados, livros eletrônicos \\
\hline Interativo & Formulário de Registro, jogos online, apresentação \\
& de informação customizada \\
\hline Transacional & Compras eletrônicas, serviços de bancos \\
\hline Workflow & Sistemas de Planejamento, gerenciamento de \\
\hline inventário, monitoria de status & \\
\hline Corporativo & Sistemas de autorização distribuídos, ferramentas de \\
\hline Comunidades Online & projeto colaborativo \\
\hline Portais Web & serviços sistemas que recomendam produtos ou \\
\hline & A aplicação direciona o usuário para outro conteúdo \\
& ou serviço Web fora do domínio da aplicação do \\
\hline
\end{tabular}

Determinadas características são geralmente citadas para descrever as aplicações Web, entre elas, as principais são: evolução contínua, pressão de tempo (urgência de entrega, imediatismo), impulsionadas pelo conteúdo, usuários remotos e diversificado.

\section{Evolução Contínua.}

A característica central do desenvolvimento Web é sua natureza "orgânica". As aplicações Web evoluem continuamente, mudam e crescem rapidamente em seus requisitos, conteúdos e funcionalidades durante todo o seu ciclo de vida [Ginige \& Murugesan, 2001a]. Diferentemente das aplicações convencionais que evoluem ao longo de uma série de versões planejadas e cronologicamente definidas e espaçadas [Pressman, 2003]. Portanto, o seu desenvolvimento é uma atividade contínua, é como o cultivo de um jardim - ele continua a evoluir e a crescer [Holck, 2003]. As mudanças contínuas ocorrem devido a alta competição no mercado. As aplicações Web sofrem mudanças, principalmente, para atender as necessidades de negócio em 
oferecer inovações para os usuários. E também, ocorre devido a indefinição de se estabelecer os requisitos por parte do cliente, que muitas vezes não conhece, no inicio do projeto, as possibilidades que a Web oferece.

\section{Pressão de tempo}

Uma outra pecularidade do desenvolvimento Web é a grande pressão de tempo, também referenciada como desenvolvimento no "Web time", "Internet time" ou "timeto-market" [Holck,2003]. Aplicações de Web têm um "imediatismo" que não é encontrado em nenhum outro tipo de software [Pressman, 2002]. A resolução rápida de problemas, a entrega imediata de novas funcionalidades ou de um Web site completo são ditados pela pressão do domínio do negócio. O sucesso de um projeto de Web, entre outros fatores, depende de quão rápido se atende às necessidades do usuário e do negócio.

\section{Conteúdo}

As aplicações fornecem um complexo conjunto de conteúdo e funcionalidades para os usuários. A apresentação de informações e a interação da aplicação com o usuário são feitas através de textos, gráficos, áudio, vídeo, ou seja, através da hipermídia e do hipertexto. Como, geralmente, uma aplicação é projetada para o mercado, para vender produtos ou idéias, a estética é muito importante e tem tanto a ver com sucesso da aplicação quanto o projeto técnico [Pressman, 2002]. Como os usuários possuem inúmeras alternativas de soluções, eles não se satisfazem com interfaces meramente funcionais. Então, a criação de aplicações Web esteticamente agradáveis tornou-se aspecto primordial do processo de desenvolvimento.

\section{Usuários remotos e diversificados}

Por sua natureza, uma aplicação Web é uma estrutura que reside numa rede e serve às necessidades de uma comunidade diversificada de usuários, que vão além dos confinamentos de departamentos, divisões ou organizações. Uma das conseqüências é que os desenvolvedores, em geral, não conhecem quem são os usuários, o que torna a caracterização mais difícil. O acesso é universal por indivíduos com habilidade

limitada ou nenhuma no uso de aplicações de computador, o que introduz a necessidade de novas interfaces homem-máquina capazes de capturar a atenção do 
usuário e facilitar o acesso à informação. Para projetar interfaces, a organização deve considerar usuários não conhecidos, atuais e futuros, e competir com interfaces que os concorrentes criam. Os usuários não estão "presos" em uma aplicação Web como poderiam estar numa aplicação tradicional ou num produto que tenham comprado. $\mathrm{Na}$ menor dificuldade, o usuário tende mover-se para outra aplicação, e provavelmente não mais retornará.

Devido a sua natureza, o desenvolvimento de uma aplicação Web lida com requisitos diversificados, tais como a necessidade de manusear dados estruturados (ex. registros de database) e não-estruturados (itens multimídia); suporte de acesso exploratório através de interfaces de navegação; nível alto de qualidade gráfica; customização e possibilidade de adaptação dinâmica da estrutura de conteúdo, de navegação e de estilo de apresentação [Fratenali, 1999]. Esses requisitos adicionam e tipicamente competem com questões técnicas e de gerenciamento como de toda aplicação de software e de uso intensivo de dados, como por exemplo: segurança, escalabilidade, interoperabilidade com sistemas legados e dados e facilidade de evolução e manutenção.

Em virtude das particularidades do desenvolvimento de aplicações Web, tem crescido o interesse de diversos pesquisadores em consolidar uma disciplina específica para estudar essas aplicações: a Engenharia de Web. No próximo tópico, a Engenharia de Web é descrita, assim como nos posteriores, são descritas as perspectivas do desenvolvimento dessas aplicações.

\subsection{ENGENHARIA DE WEB}

Em 1997, os membros de um grupo de pesquisa da Universidade de Western Sydney, Austrália, chamado WebISM (Web-based Information Systems and Methodologies) conduziram os esforços para identificar e desenvolver o campo da Engenharia de Web. O primeiro workshop de Engenharia de Web aconteceu na conferência World Wide Web em Brisbane, Austrália, em 1998. A partir de então outros similares workshops aconteceram nesta área. E em 1998, a Engenharia de Web foi estabelecida como uma nova disciplina na Universidade de Western Sydney. Desde então, tem ganhado atenção da comunidade de 
software e atraído profissionais de outras disciplinas relacionadas. O interesse por esta área tem crescido à medida que os sistemas Web se tornaram elementos críticos para um grande número de aplicações e com o crescimento do uso da Web como ferramenta de negócio [Ginige e Murugesan, 2001a; Ginige, 2002].

Os pesquisadores que primeiro propuseram a necessidade de uma abordagem de Engenharia para o desenvolvimento de aplicações Web definem a Engenharia de Web como segue:

Engenharia de Web lida com o estabelecimento e uso de princípios científicos, da engenharia e de gerenciamento, de abordagens sistemáticas e disciplinadas para que sejam bem sucedidos o desenvolvimento, entrega $e$ manutenção de aplicações de alta qualidade.

A Engenharia de Web lida com todos os aspectos do desenvolvimento de sistemas Web, desde a concepção e seu desenvolvimento até a implementação, avaliação e sua evolução. Sua essência é gerenciar a diversidade e a complexidade do desenvolvimento das aplicações Web e, assim, evitar falhas no projeto que possam causar grandes implicações [Ginige \& Murugesan, 2001b].

Engenharia de Web abrange diversos princípios da Engenharia de Software, mas não é uma cópia desta. Ela incorpora novas abordagens, metodologias, técnicas e diretrizes para adequar-se aos requisitos dos sistemas Web. O desenvolvimento de sistemas Web impõe desafios adicionais aqueles encontrados no desenvolvimento de softwares tradicionais. Há diferenças na natureza do ciclo de vida, na maneira pela qual são desenvolvidos e mantidos.

Entre as áreas relacionadas com o desenvolvimento de aplicações Web, estão incluídas [Ginige et al, 1998]:

- Especificação e análise de requisitos;

- Análise e projeto de sistemas;

- Metodologias e técnicas para o desenvolvimento de sistemas;

- Integração com sistemas legados; migração de sistemas legados para a Web

- Desenvolvimento de aplicações em tempo real;

- Técnicas e ferramentas de teste, verificação e validação; 
- Garantia, controle e avaliação da qualidade;

- Gerenciamento de configuração;

- Métricas para a Web - métricas para estimação dos esforços de desenvolvimento;

- Especificação e avaliação de performance;

- Atualização e manutenção;

- Questões de segurança, de privacidade, legal, social e outras questões não técnicas;

- Personalização da Web;

- Equipes de desenvolvimento;

- Gerenciamento de projeto Web;

- Aspectos culturais e humanos;

- Desenvolvimento centrado no usuário;

- Educação e treinamento;

\subsection{PERSPECtivas No DesenVolvimento DE Aplicações Web}

\subsection{PROCESSO DE DESENVOLVIMENTO}

As aplicações Web desenvolveram-se dentro de sistemas complexos e críticos, o que significa que precisam ser tratados como tal [Li et al, 2000]. Algumas características das aplicações Web tornam seu desenvolvimento difícil - e unicamente desafiante - e incluem sua interação em tempo real, complexidade, mudanças constantes e a necessidade de fornecer informação personalizada [Ginige \& Murugesan, 2001b]. A aplicação Web fornece acesso estruturado a um grande número de informação, possivelmente sob diferentes visões e através de diferentes contextos.

A melhor forma de gerenciar o projeto e o desenvolvimento de uma aplicação Web, assim como de qualquer outro sistema, é através de uma maneira sistemática e repetível. Dessa forma, é necessário um processo que descreva as várias fases, passos e atividades do 
desenvolvimento da aplicação. Um processo sólido ajuda os desenvolvedores a tratar a complexidade da aplicação, minimizar os riscos do desenvolvimento, lidar com a probabilidade de mudança, e a entrega das aplicações no prazo, ao mesmo tempo fornece avaliação prévia para o gerenciamento enquanto o projeto continua [Ginige \& Murugesan, 2001b].

Os dois atributos chaves do sistema Web que distinguem seu desenvolvimento do tradicional desenvolvimento de software são o crescimento de seus requisitos e a contínua mudança no conteúdo da informação. Na maioria dos casos, não é possível especificar totalmente no início do desenvolvimento o que uma aplicação Web irá conter, porque sua estrutura e funcionalidades evoluem com o tempo. Além disso, a informação apresentada pela aplicação também mudará. A habilidade de gerenciar a informação e de escalar a estrutura da aplicação são dois grandes fatores que devem ser considerados quando se desenvolve uma aplicação Web [Ginige, 2001b].

Sendo assim, o processo de desenvolvimento deve ser interativo e incremental para atender a natureza evolutiva das aplicações Web. O processo deve facilitar o contínuo refinamento e evolução das aplicações baseado no feedback dos usuários e clientes [Ginige \& Murugesan, 2001b].

Contudo, segundo Pressman em [Pressman, 2002] a natureza imediatista das aplicações Web associada com a pressão de evolução contínua impõe o estabelecimento de um projeto de desenvolvimento com a capacidade de resolver de imediato o problema de negócio, e ao mesmo tempo definir uma arquitetura que tenha a habilidade de evoluir rapidamente. Porém, a maneira com que o problema é resolvido imediatamente, pode afetar a capacidade da aplicação de evoluir ao longo do tempo.

O projeto de uma aplicação Web demanda balanço entre o conteúdo da informação, estética, performance e sistemas de computação, o que envolve o conhecimento de diversas disciplinas e requer uma equipe com habilidades em diferentes áreas.

Assim, é necessário um processo para a construção de aplicações Web que [Ginige, 2002]: 
- Seja eficiente para capturar a mudança de requisitos e para o gerenciamento da complexidade do processo de desenvolvimento.

- Permita a integração do conhecimento de várias disciplinas.

- Facilite a comunicação entre os vários membros envolvidos no desenvolvimento da aplicação - a equipe de desenvolvimento, os usuários finais, clientes e outros.

- Suporte a evolução contínua, a manutenção e o gerenciamento do conteúdo.

Apesar de não existir um consenso sobre um modelo geral de ciclo de vida de uma aplicação Web - o ponto em comum é ser evolutivo e incremental - algumas atividades típicas envolvidas na construção da aplicação são consideradas na maioria dos modelos: análise de requisitos, conceitualização, prototipação, projeto, implementação e evolução ou manutenção.

\section{Análise de Requisitos}

Durante a análise de requisitos o desenvolvedor coleta as necessidades em termos de conteúdo, estruturação, acesso e estética. Requisitos de conteúdo definem a informação do domínio específico que deve estar disponível através da aplicação. Requisitos de estruturação especificam como o conteúdo deve ser organizado. Requisitos de acesso definem o estilo de acesso da informação que deve ser providenciada, o que inclui prioridades na apresentação da informação, indexação dos conteúdos, facilidades de pesquisas e suporte. Requisitos de estética definem as propriedades da aparência em geral [Coda et al, 1998].

A missão da aplicação é estabelecida pela identificação dos usuários, pela definição da natureza da informação e objetivos. Em adição aos requisitos freqüentes, as aplicações Web, projetadas para acesso universal, requererem atenção especial na identificação dos requisitos de interação usuário-computador, para estabelecer o modo de interação mais apropriado para cada categoria esperada de usuários, e para cada tipo de dispositivo de saída que se espera que o usuário use para conectar-se com a aplicação (desde aparelhos pessoais de mão até telas de alta definição] [Fratenali, 1999]. 
Um grande desafio no desenvolvimento das aplicações Web é a tradução das perspectivas dinâmicas dos requisitos dos usuários em um projeto lógico de um sistema funcional, especialmente na situação onde o projeto e a implementação da solução são baseados numa idéia central a qual seus requisitos mudam rapidamente [Chaubey \& Suresh, 2001]. A dificuldade cresce da necessidade de integrar novos serviços às funcionalidades básicas a cada nova interação do desenvolvimento da solução.

\section{Conceitualização}

A aplicação é representada através de um conjunto de modelos abstratos que conduzem aos componentes principais da solução. No contexto da Web, o foco da conceitualização está na captura de objetos e relacionamentos de como irão aparecer para o usuário, mais do que como serão representados dentro do sistema. O esquema resultante da conceitualização da aplicação Web difere-se de uma aplicação de banco de dados. A diferença está na interpretação dos relacionamentos, na qual a modelagem do banco de dados representa associações semânticas que são constantemente gravadas enquanto que na modelagem Web uma possibilidade de navegação está implícita [Fratenali, 1999].

\section{Prototipação}

Versões simplificadas das aplicações são entregues para os clientes para uma avaliação prévia. A importância da prototipação é particularmente enfatizada no contexto da Web. Tipicamente, protótipos são construídos numa arquitetura simplificada. Um conjunto de páginas são implementadas manualmente contendo amostras do conteúdo da aplicação e da estética, simula o desejo da aparência e comportamento.

\section{Projeto}

Baseado nos requisitos, a fase de projeto define a estrutura de um Web site, descrevendo como a informação pode ser organizada e como os usuários podem navegar através dela. As atividades de projeto devem destacar as constituições fundamentais de um site, abstraindo-se dos detalhes de implementação de baixo nível, e permitir ao projetista identificar estruturas recorrentes e padrões de navegação para serem reusados. Um bom projeto sobrevive às mudanças freqüentes na implementação. 
A aplicação Web é caracterizada por três grandes projetos:

> Arquitetural ou estrutural. Descreve a organização da informação gerenciada pela aplicação, em termos de partes de conteúdo que constituem a base de informação e do relacionamento semântico. A estrutura arquitetural é ligada às metas estabelecidas para a aplicação, ao conteúdo a ser apresentado, aos usuários e à navegação que for estabelecida [Pressman, 2003].

> Navegacional. O projetista deve definir caminhos de navegação que permitam ao usuário ter acesso ao conteúdo e aos serviços da aplicação. Nesta etapa, preocupa-se com as facilidades para acessar a informação e para se mover através do conteúdo da aplicação. Para tanto, o projetista precisa identificar a semântica de navegação para diferentes usuários e definir a mecânica para realizar a navegação. Para cada objetivo associado às características do usuário é criado o melhor modo ou caminho de navegação [Pressman, 2003].

> Apresentação. Afeta a maneira pela qual o conteúdo da aplicação e os comandos de navegação são apresentados para o usuário. [Fratenali, 1999]. Uma interface bem projetada melhora a percepção do usuário em relação aos serviços fornecidos pela aplicação.

\section{Implementação}

A fase de implementação cria a aplicação a partir do projeto. Os elementos e relacionamentos destacados durante o projeto são mapeados na construção com a tecnologia de implementação escolhida. Entidades, componentes, links e estruturas de acesso são associados com outros elementos fornecidos pela tecnologia hipermídia. O site é "povoado", ou seja, a informação corrente é inserida pela instanciação das estruturas definidas. O banco de dados é preenchido com o novo conteúdo preparado por especialistas no assunto e/ou com os dados armazenados nos sistemas legados; as páginas são construídas pela combinação do conteúdo do banco de dados e comandos navegacionais dentro de um estilo de apresentação. $\mathrm{O}$ mapeamento do projeto para a implementação requer a escolha de uma linguagem de rede 
na qual a aplicação é entregue. Por último o sistema é entregue. O site implementado deve ser acessível usando padrões de Internet que interagem com servidores.

\section{Evolução e manutenção}

Depois de entregue, mudanças nos requisitos ou o conserto de erros podem requerer a revisão da estrutura, navegação, apresentação ou conteúdo. As mudanças são aplicadas no nível mais alto possível no ciclo de desenvolvimento e propagadas até o nível de implementação [Fratenali, 1999].

Ginige em [Ginige\&Murugesan, 2001b], baseado em pesquisas e na experiência na construção de aplicações Web, recomenda dez passos chaves para o sucesso no desenvolvimento dessas aplicações:

1. Entender todas as funções do sistema e o ambiente operacional, inclusive os requisitos e objetivos do negócio.

2. Claramente identificar os principais usuários do sistema, a organização que precisa do sistema e os que financiam o desenvolvimento do sistema.

3. Especificar os requisitos técnicos e não técnicos.

4. Desenvolver a arquitetura do sistema Web que atenda os requisitos técnicos e não técnicos.

5. Identificar subprocessos ou subprojetos para implementar a arquitetura. Se os subprocessos são muito complexos para gerenciar, dividi-los novamente até que se tornem um conjunto de tarefas gerenciáveis.

6. Desenvolver e implementar subprojetos.

7. Incorporar mecanismos para gerenciar a evolução e mudança/manutenção do sistema. Enquanto o sistema é desenvolvido, todo o processo ou parte dele pode ser repetido quando requisitado.

8. Tratar questões não técnicas tais como processos de negócio; políticas organizacionais e de gerenciamento, recursos humanos; aspectos legal, social e cultural.

9. Medir a performance do sistema.

10. Refinar e atualizar o sistema. 


\subsubsection{A EQUIPE}

A organização das equipes das aplicações Web tem semelhanças com a das equipes de sistemas tradicionais, sendo que alguns papéis são os mesmos, como programadores, arquitetos de software, analista de sistema, gerente de projeto, analista de requisitos e outros. Porém, os profissionais devem ter habilidades que convergem o conhecimento técnico e não técnico [Pressman, 2002].

Para o desenvolvimento de aplicações Web são necessários conhecimentos e habilidades de diferentes disciplinas, requer uma equipe de diversas pessoas com especialidades em diferentes áreas [Ginige \& Murugesan, 2001b]. Precisa-se de projetistas gráficos para desenvolver a aparência; de pessoas para organizar a informação, desenvolver a navegação e os mecanismos de buscas; projetistas de banco de dados para desenvolver a maneira pela qual a informação é armazenada e acessada; programadores; especialistas em segurança de rede; especialistas para decidir qual a melhor arquitetura de hardware; e pessoas com o conhecimento para planejar o projeto de desenvolvimento e gerenciá-lo [Ginige, 2002].

Segundo Pressman em [Pressman, 2002], os seguintes papéis podem ser distribuídos entre os membros da equipe de desenvolvimento de aplicações Web:

Provedor de conteúdo. Seu papel é voltado para a geração ou coleta de conteúdo. Estes profissionais são oriundos de diversas áreas. Por exemplo, redatores podem fornecer texto, produtores de mídia podem fornecer vídeo e áudio e o pessoal de venda e de marketing podem fornecer informações sobre o produto.

Editor de Web. Seu papel é organizar a inclusão do conteúdo e age como ligação entre a equipe técnica que constrói as aplicações e os desenvolvedores e provedores de conteúdo não-técnico.

Engenheiro de Web. Envolve-se em diversas atividades: modelagem e análise de dados, projeto arquitetural, navegacional e de interface; implementação e 
teste. Ele deve ter conhecimentos em tecnologias de componentes, arquiteturas cliente/servidor, linguagens de marcação (html e XML) base de dados, multimídia e segurança de rede.

$>$ Especialista de suporte. Pessoa responsável em dar continuidade ao suporte da aplicação. É responsável por correções, adaptações e aperfeiçoamentos do site, o que inclui modificações de conteúdo, de navegação, e implementação de novos procedimentos.

Administrador (Web Master). É responsável pela operação do dia-a-dia da aplicação: medição do tráfego na aplicação; coordenação de procedimentos para modificações; coordenação dos especialistas de suporte; implementação de procedimentos de segurança e direitos de acesso e desenvolvimento de políticas de operação da aplicação.

O papel de Engenheiro de Web pode ser dividido em outros papéis mais específicos, como: arquiteto de informação, que é responsável pela organização das informações nas páginas, Web designer, que é responsável pelo desenho estético, programador html que implementa as páginas e engenheiros de segurança de informação, que definem métodos para garantir a segurança de acesso e distribuição das informações.

Uma equipe tão multidisciplinar constitui um novo desafio para diversas atividades do gerenciamento do desenvolvimento das aplicações: o gerenciamento do projeto deve abranger não só atividades técnicas, mas as não-técnicas também; a comunicação é mais complicada e o gerente deve garantir o bom entendimento; os documentos gerados devem englobar as diferentes linguagens utilizadas pelos diferentes perfis de profissionais em um padrão que garanta o bom entendimento de todos.

\subsubsection{ATRIBUTOS DE QUALIDADE}

A Web é um ambiente complexo e, conseqüentemente, a avaliação de produtos de software é uma tarefa difícil dado o conjunto de características e particularidades envolvidas [Rocha et al, 2001]. Exige um processo de garantia de qualidade que considere diferentes 
aspectos que abrangem desde a qualidade da interface no que se refere ao uso de recursos gráficos e cores até a necessidade de garantir a correção do conteúdo disponibilizado e a segurança de informações e de acesso.

Em geral, todos os atributos de qualidade de software se aplicam aos sistemas baseados na Web. No entanto, há os mais relevantes que fornecem uma base útil para avaliar a qualidade. Em [Pressman, 2002] é apresentado uma árvore de requisitos de qualidade, ver Figura 1, que identifica um conjunto de atributos que levam à alta qualidade de aplicações Web considerando as seis características da ISO/IEC 9126 [ISO/IEC 9126,1991] .

\begin{tabular}{|c|c|}
\hline Usabilidade & $\begin{array}{l}\text { Compreensibilidade global do site } \\
\text { Características de realimentação e ajuda on-line } \\
\text { Característica de interface e estética } \\
\text { Características especiais }\end{array}$ \\
\hline Funcionalidade & $\begin{array}{l}\text { Capacidade de busca e recuperação } \\
\text { Características de navegação e busca } \\
\text { Características relacionadas ao domínio de } \\
\text { aplicação }\end{array}$ \\
\hline Confiabilidade & $\begin{array}{l}\text { Processamento correto de links } \\
\text { Recuperação de erros } \\
\text { Validação e recuperação de entrada do usuário }\end{array}$ \\
\hline Eficiência & $\begin{array}{l}\text { Desempenho em tempo de resposta } \\
\text { Velocidade de geração de página } \\
\text { Velocidade de geração de gráficos }\end{array}$ \\
\hline Mantenabilidade & $\begin{array}{l}\text { Facilidade de correção } \\
\text { Adaptabilidade } \\
\text { Estensabilidade }\end{array}$ \\
\hline
\end{tabular}

Figura 1: Atributos de Qualidade 
Vários outros trabalhos têm sido apresentados na literatura sobre o que e como avaliar as aplicações Web [Bevan,1997; Borges,1996; Olsina,1999; Lowe,1999; Lima et al,2000]. Um outro conjunto de atributos pode ser visto em Lima et al [2000], que abrange aspectos referentes ao uso da tecnologia e ao conteúdo disponibilizado.

Lynch et al [1999] descreve as características desejáveis para sites Web, considerando que os usuários de documentos da Web não buscam apenas informação, mas interagem com esses documentos de uma nova forma. $\mathrm{O}$ autor recomenda que o projeto seja centrado nos usuários em potencial, buscando atender às suas expectativas. Para isso a aplicação deve ter as seguintes características:

- Apoio à navegação, fornecendo confiança de que o usuário pode encontrar o que está procurando sem perda de tempo;

- Acesso direto para que o usuário encontre as informações rapidamente;

- Eficiência de tempo de resposta;

- Simplicidade e consistência nas metáforas;

- Organização lógica do site;

- Métodos consistentes para disponibilizar informações que permitam ao usuário passar, com facilidade, de páginas familiares a páginas não familiares;

- Funcionalidade adequada, com hierarquia de menus e páginas que seja natural ao usuário.

Entre outros fatores, a escalabilidade e mantenabilidade são determinantes no sucesso na implementação e manutenção dos sistemas Web. Já que, como foi dito, o conteúdo da informação e as funções tendem a serem aprimorados/evoluídos durante o ciclo de vida. Esses atributos dificilmente podem ser adicionados mais tarde [Ginige, 2002].

Um fator importantíssimo é a usabilidade. A usabilidade ou a experiência do usuário são determinantes críticos para o sucesso de aplicações Web. Interfaces mal projetadas aumentam a chance de erros por parte do usuário. Jakob Nielsen [Constantine \& Lockwood, 2002], especialista em usabilidade de Web, estima que bilhões de dólares sejam perdidos em vendas pela Web por problemas de usabilidade.

Custos de suporte ao usuário e técnicos em todas as áreas de negócio estão cada vez mais altos. Problemas com usabilidade no site ou numa aplicação desencadeiam uma chamada 
telefônica ou mensagem via e-mail para o atendimento ao cliente, uma sessão de Web "barata" torna-se uma ocorrência de atendimento cara. Em intranets, aplicações difíceis de usar requerem extensivo treinamento ou tornam-se completamente sem uso [Constantine \& Lockwood, 2002].

Usabilidade é uma das mais importantes características de qualidade de produtos e sistemas de software. Um sistema com alta qualidade de usabilidade é fácil de aprender, eficiente para o uso, não tende a erros e satisfatório ao uso [Nielsen,1995]. Usabilidade traz muitos benefícios, que incluem aumento de produtividade, melhoria de qualidade no trabalho, melhoria da satisfação do usuário, redução de suporte e custo de treinamento, e melhoria da satisfação do usuário [ISO/IEC 13407, 1999]. O paradigma que prevalece para o desenvolvimento de produtos e sistemas com interação com o usuário é a Engenharia de Usabilidade, também chamado projeto user-centered (centralizado no usuário, em português) ou human-centered (centralizado no homem) [Jokela, 2002].

Um típico conjunto de atividades de usabilidade é definido na ISO13407 [ISO/IEC 13407, 1999]. O padrão identifica quatro atividades ilustradas na Figura 2.

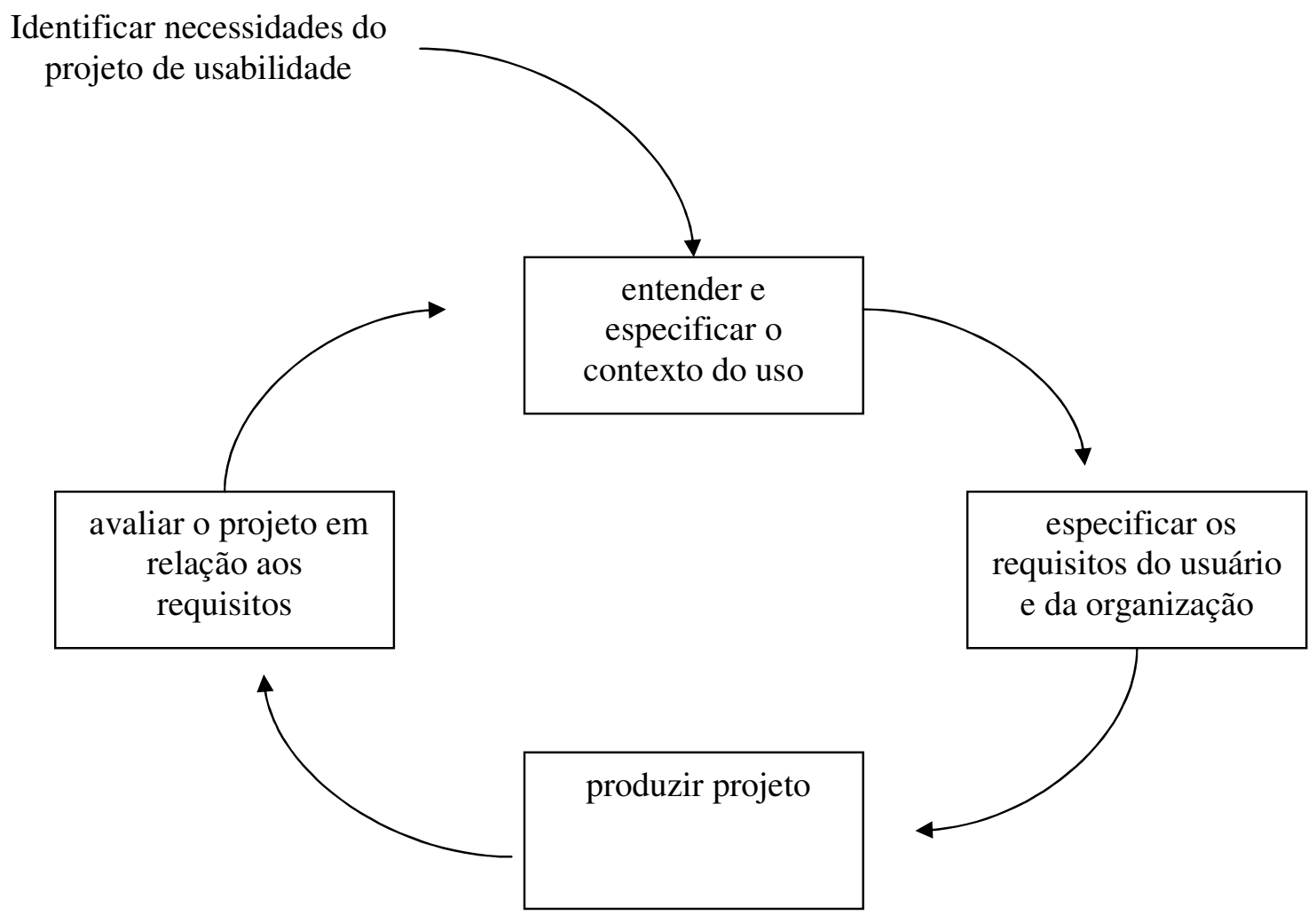

Figura 2: Processo de Engenharia de Usabilidade definido na ISO 13407 
O valor da usabilidade é amplamente conhecido, diversos pesquisadores têm descrito seu valor em benefício do usuário, desenvolvedor e da organização como um todo[Schneiderman, 1998; Constantine \& Lockwood,1999]. Apesar de frequentemente considerarem a aparência de uma interface gráfica como a essência da usabilidade, a usabilidade engloba muito mais, principalmente em relação às aplicações Web. Juristo et al [2001] explica que usabilidade de um sistema não apenas lida com a interface do usuário, está também relacionado com toda a estrutura do software e com o conceito na qual todo o sistema é baseado. O que é necessário é garantir que a usabilidade faça parte do processo de desenvolvimento da aplicação [ Becker \& Berkermeyer,2002].

Os desenvolvedores devem alinhar os objetivos de usabilidade como o desenvolvimento Web e como os objetivos do usuário, assim, é importante definir o perfil de usuário para entender a usabilidade da sua perspectiva. $\mathrm{O}$ usuário pode ter o perfil definido em termos de idade, sexo, localização geográfica, cultura, religião, nível de renda, grau de instrução e habilidades cognitivas, visuais e físicas [ Becker \& Berkermeyer, 2002]. Cada uma dessas características tem uma influência nas percepções do usuário da aplicação Web. O ambiente do usuário também afeta a percepção de usabilidade. Tipo de browser, tamanho do monitor, velocidade de acesso a rede são exemplos de tecnologias que impactam a experiência do usuário [Neurkar, 2001].

A usabilidade é, significantemente, associada a cinco elementos básicos de um projeto Web: navegação, tempo de resposta, conteúdo, interatividade e compreensão (responsiveness). Uma boa estrutura navegacional apóia o usuário em adquirir a informação que está procurando eficiente e rapidamente. Os usuários demandam que as páginas de uma aplicação carreguem rapidamente. Eles começam a perder a paciência dentro de poucos segundos. Quanto mais tempo usuários gastam dentro de uma aplicação, menos tolerância eles têm.

Os aspectos do projeto estético também figuram na experiência do usuário. Agora que os usuários de aplicações Web possuem alternativas, eles não se satisfazem com interfaces meramente funcionais. As considerações de projeto gráfico e da estética são estabelecidas a priori e dirigem o processo de desenvolvimento [Constantine \& Lockwood, 2002]. 


\subsection{CONSIDERAÇÕES FINAIS}

As aplicações Web são definidas por um conjunto de características que as tornam diferentes das aplicações tradicionais da tecnologia da informação. Por isso, neste capítulo fez-se necessário a apresentação de tais características, para que o trabalho fosse embasado em aspectos notórios ao desenvolvimento dessas aplicações.

Em virtude das particularidades das aplicações Web, novas metodologias direcionadas para o desenvolvimento são necessárias, porém, métodos consagrados na Engenharia de Software continuam aplicáveis.

Sendo assim, no próximo capítulo a norma ISO/IEC 12207 é apresentada, já que essa é a base principal dos Processos de Apoio ao desenvolvimento Web propostos neste trabalho. 


\section{CAPÍTULO 3: ISO/IEC 12207 - PROCESSOS DO CICLO DE VIDA DO}

SOFTWARE

\section{1 CONSIDERAÇÕES INICIAIS}

Para o desenvolvimento e manutenção de software existe uma proliferação de padrões, procedimentos, métodos, ferramentas e ambientes. que tem criado dificuldades na engenharia e manutenção do software, especialmente na integração de produtos e serviços. A disciplina de software precisa migrar de uma proliferação para uma arquitetura comum que possa ser usada pelos profissionais de software para criar e gerenciar o software através de "uma linguagem comum" [IEEE/EIA 12207, 1996]. A Norma Internacional 12207 fornece tal arquitetura.

A ISO/IEC 12207 é a primeira norma internacional que descreve em detalhes processos, atividades e tarefas que são aplicados para a aquisição, fornecimento, desenvolvimento e manutenção do software. Publicada em Agosto de 1995, ela serve como referência para outros padrões, sendo citada em diversos trabalhos relacionados com Engenharia de Software.

A Norma cobre todo o ciclo de vida de software e consiste de um conjunto de processos, atividades e tarefas bem definidas. 
Neste Capítulo, além de uma visão geral da Norma, serão apresentados em maiores detalhes os Processos de Apoio, uma vez que tal assunto é o foco do trabalho a ser proposto.

Este capítulo é fortemente baseado em [ISO/IEC 12207, 1995].

\subsection{VISÃO GERAL}

A ISO/IEC 12207 estabelece uma arquitetura de alto nível para os processos de ciclo de vida do software, com terminologia bem definida, que serve como referência à indústria de software. O ciclo de vida começa com uma idéia ou necessidade que pode ser satisfeita total ou parcialmente por um software e termina com a descontinuidade do mesmo. Contem processos, atividades, e tarefas que são aplicados durante a aquisição, fornecimento, desenvolvimento, operação, e manutenção dos produtos de software [ISO/IEC 12207, 1995].

Por meio de processos bem definidos, a Norma 12207 auxilia os envolvidos na produção de software a definir seus papéis e, conseqüentemente, proporciona às organizações que a utilizam, um melhor entendimento das atividades que envolvem, de alguma forma o software. [Rocha et al, 2001].

A estrutura da norma foi concebida de maneira a ser flexível, modular e adaptável às necessidades de quem a utiliza. O modelo é construído com um conjunto de processos chaves e o inter-relacionamento entre eles e é baseado em dois princípios básicos: modularidade e responsabilidade [IEEE/EIA 12207,1996]:

Modularidade. Os processos são modulares, isto é, eles têm alta coesão e baixo acoplamento. Os processos são fortemente relacionados com um mínimo de interfaces. Um processo individual é dedicado a uma única função. Se uma função é invocada por mais de um processo, então a função torna-se um processo. Cada processo possui uma estrutura interna refinada o suficiente para ser executada.

Responsabilidade. Um processo é de responsabilidade de uma organização ou parte dela durante o ciclo de vida do software, apesar da execução de tarefas 
individuais poderem ser realizadas por pessoas diferentes. A responsabilidade determinada na norma facilita a adaptação e aplicação em projetos de diferentes tipos, produtos e tamanho.

Os processos, aplicáveis através do ciclo de vida do produto, podem ser interpretados, implementados e usados de modos diferentes por diferentes organizações e partes organizacionais, todos com diferentes visões, necessidades, percepções e objetivos. A Norma define as visões das seguintes funções:

a. contratação: o adquirente e o fornecedor negociam e estabelecem um "contrato".

b. gerenciamento: o adquirente, fornecedor, desenvolvedor, operador, mantenedor e outras partes gerenciam seus processos particulares.

c. operação: fornece serviços para os usuários.

d. engenharia:o desenvolvedor e mantenedor conduz suas tarefas para produzir um produto.

e. suporte: fornecem suporte a outras partes na execução de suas tarefas específicas.

f. gerenciamento de qualidade: um subconjunto de suporte é empregado para gerenciar questões relacionadas com qualidade através de todo o ciclo de vida.

A ISO/IEC 12207 é modelada numa hierarquia com processos de alto nível. Cada processo é projetado em termos de suas próprias atividades, que por sua vez, são projetadas em termos de suas tarefas. Os processos são agrupados nas seguintes classes que representam sua natureza:

1) Processos Fundamentais: iniciam e executam o desenvolvimento, operação e manutenção dos produtos de software;

2) Processos de Apoio: têm como objetivo auxiliar outros processos, visando principalmente a qualidade e o sucesso do projeto;

3) Processos Organizacionais: estabelecem e implementam uma estrutura constituída dos processos de ciclo de vida e pelo pessoal envolvido no desenvolvimento de software.

4) Processos de Adaptação: definem as atividades necessárias para adaptar a norma para a sua aplicação na organização ou em projetos. 
Os processos de cada classe são mostrados na Figura 3.

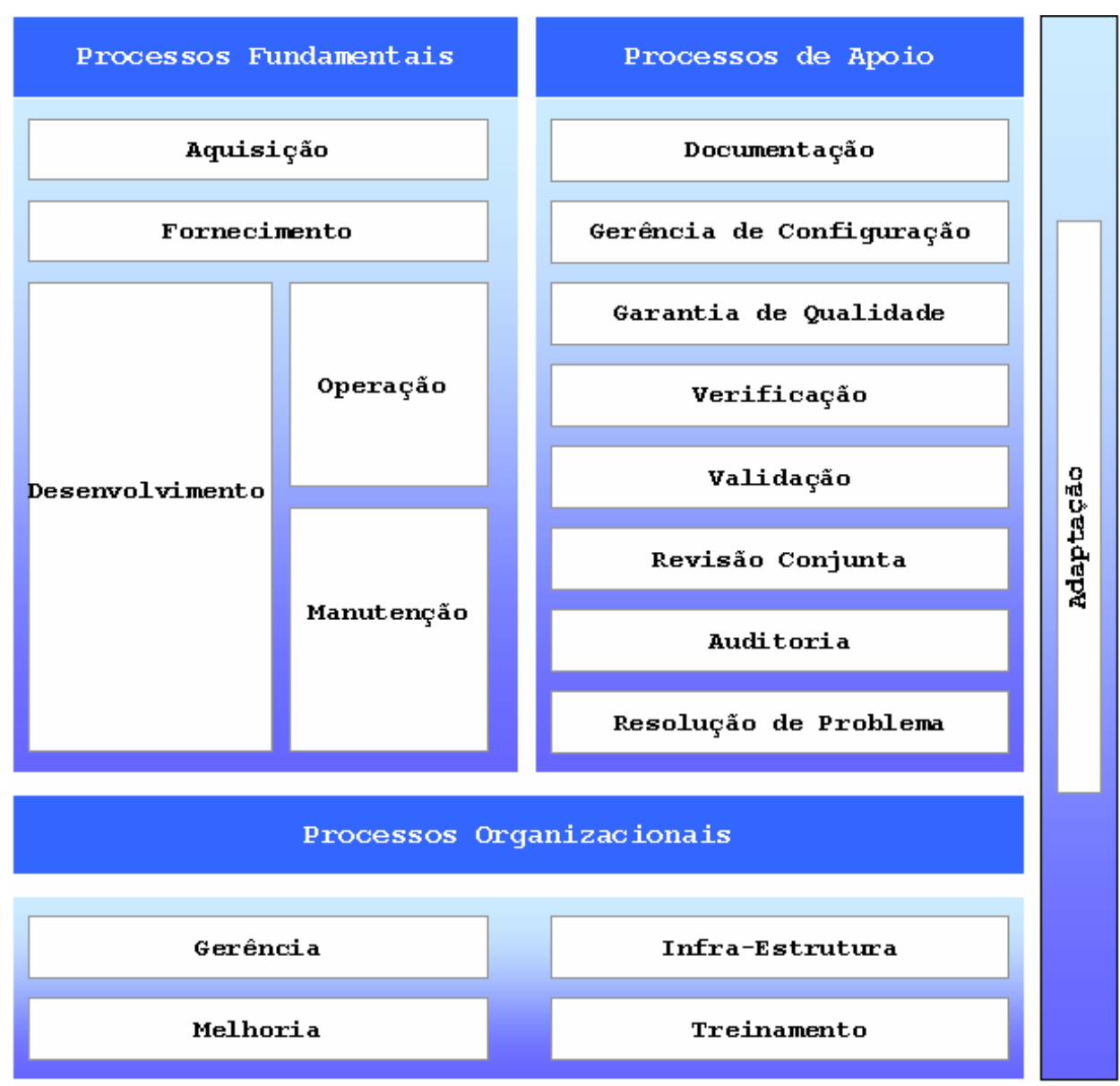

Figura 3: Processos do Ciclo de Vida do Software

Como o objetivo deste trabalho envolve, principalmente, os Processos de Apoio da Norma, a seguir eles são descritos mais detalhadamente. 


\subsection{ISO/IEC 12207 - Processos DE APOIO}

Um processo de apoio dá suporte a outro processo - como parte integral deste, mas com um propósito distinto. A classe dos Processos de Apoio consiste de oito processos:

1) Documentação;

2) Gerenciamento de Configuração de Software;

3) Garantia de Qualidade de Software;

4) Verificação;

5) Validação;

6) Revisão Conjunta;

7) Auditoria;

8) Resolução de Problemas.

Nas próximas seções, esses processos são detalhados.

\subsubsection{DOCUMENTAÇÃO}

De acordo com a Norma ISO/IEC 12207, o processo de Documentação tem o objetivo de registrar as informações produzidas pelos processos ou atividades durante ciclo de vida do software. O conjunto de atividades do processo planeja, projeta, desenvolve, produz, edita, distribui e mantém os documentos necessários à todos os interessados, tais como, gerentes, engenheiros, e usuários do sistema ou do produto de software.

A documentação de software é fundamental no processo de desenvolvimento de software. Cabe a documentação registrar a evolução do software para criar as condições necessárias para que a utilização, avaliação e manutenção do software sejam realizadas sem transtornos [Rocha et al, 2001].

Uma documentação bem elaborada além de proporcionar grandes benefícios para as atividades de avaliação e modificação de software, reduz tempo e esforço despendidos no desenvolvimento do software; facilita o manuseio do software por parte dos usuários; facilita 
a localização das informações e garante uma melhor compreensão das estruturas do software [Phoha, 1997].

O processo de Documentação consiste de quatro classes principais de atividades:

1) Implementação do Processo;

2) Projeto e Desenvolvimento;

3) Produção;

4) Manutenção.

\section{Implementação de Processo}

A atividade de Implementação do Processo consiste nas tarefas de desenvolver, documentar e implementar um plano que identifique os documentos a serem produzidos durante o ciclo de vida do produto de software. Neste plano, além do tipo de documento a ser desenvolvido, são estabelecidos: a tecnologia a ser usada, a seqüência de operações para a produção e a distribuição dos mesmos, a definição da linguagem do documento e a linguagem que será usada na indexação e referência do documento.

Para cada documento identificado, devem constar:

- seu título ou nome;

- propósito a que se destina;

- a audiência pretendida;

- procedimentos e responsabilidades para entradas, desenvolvimento, revisão, modificação, aprovação, produção, armazenamento, distribuição, manutenção e gerenciamento de configuração;

- cronograma para versões intermediárias e finais. 


\section{Projeto e Desenvolvimento}

Os diversos aspectos exigidos para a produção do documento são descritos, o que envolve desde a estrutura interna até as características de sua apresentação para o usuário final.

Nesta atividade, as seguintes tarefas devem ser consideradas:

- Cada documento identificado deve ser projetado de acordo com os padrões de documentação definidos para o formato, descrição de conteúdo, numeração de página, colocação de figura/tabela, marca de propriedade/segurança e outros itens de apresentação.

- Devem ser confirmadas a fonte e a adequação dos dados de entrada para os documentos.

- O conteúdo técnico e o estilo da apresentação dos documentos preparados devem ser revisados e editados de acordo com os padrões de documentação. Os documentos devem ser aprovados pelo pessoal autorizado que verifica se eles estão adequados ao especificado.

\section{Produção}

O objetivo desta atividade é produzir os documentos de acordo com o plano de documentação. As informações produzidas durante as atividades do ciclo de vida são registradas nos documentos que servem como ponto de partida para as demais atividades do projeto.

Os documentos principais devem ser armazenados de acordo com os requisitos de retenção, segurança, manutenção e backup. E os controles devem ser estabelecidos de acordo com o Processo de Gerenciamento de Configuração. 


\section{Manutenção}

Nesta atividade são desenvolvidas as tarefas relacionadas às alterações controladas dos documentos, à destruição dos documentos considerados obsoletos e ao armazenamento dos documentos.

As alterações dos documentos que estão sob o controle de configuração devem ser gerenciadas de acordo com o processo de Gerenciamento de Configuração de Software.

\subsubsection{GERENCIAMENTO DE CONFIGURAÇÃO DE SOFTWARE}

Durante o desenvolvimento de software, diversos itens de informação são produzidos. E estes itens podem sofrer alterações ao longo do ciclo de vida do software. Para que não existam inconsistências nos itens considerados importantes para o projeto, é necessário que as alterações sejam controladas. O processo de Gerenciamento de Configuração de Software administra as alterações ocorridas.

O processo de Gerenciamento de Configuração de Software visa: identificar e definir os itens considerados relevantes ao projeto; controlar as modificações dos itens; registrar e reportar a situação dos itens e das requisições das alterações; garantir a integridade e consistência dos itens; e controlar o armazenamento, manipulação, liberação e entrega dos itens [ISO/IEC 12207,1995].

Um conceito importante é o de item de configuração. Um item de configuração de software pode ser um produto de software - informações designadas para serem entregues a um cliente ou usuário, tais como programas de computador, procedimentos, documentação e etc - ou um produto do desenvolvimento de software - informações que podem ou não ter a finalidade de ser entregue a um cliente ou usuário final, como descrição de processos, planos, procedimentos e etc - que são escolhidos para fazerem parte da configuração de software, ou seja, a qual será realizado o controle de suas alterações. 
Um outro conceito é fundamental: linhas de referências (baselines). As linhas de referência estabelecem pontos bem definidos dentro do processo de desenvolvimento onde os itens de configuração devem ser identificados, analisados, corrigidos, aprovados e armazenados num repositório de itens de configuração.

Um repositório de itens de configuração é um banco de dados sob controle de acesso onde são armazenados os itens de configuração depois de liberados por uma linha de referência.. O método utilizado para trabalhar com itens de configuração que já estão no repositório é chamado de check-in/check-out [Bersoff, 1979; Harter, 1989], ou seja, conferência na entrada e na saída.

No processo de Gerenciamento de Configuração, as seguintes principais atividades devem ser realizadas:

1) Implementação do Processo;

2) Identificação da Configuração;

3) Controle da Configuração;

4) Relatar a Situação da Configuração;

5) Avaliação da Configuração;

6) Gerenciamento de Liberação e Entrega.

\section{Implementação do Processo}

Um plano para o Gerenciamento de Configuração deverá ser desenvolvido, documentado e implementado. Este plano deverá descrever as atividades relacionadas à implantação e administração do processo. Também devem ser descritos os procedimentos, prazos, recursos necessários e a organização responsável para executar essas atividades.

Existem vários padrões internacionais de planos de gerência de configuração. Recomenda-se que estes planos sejam estudados e que seja escolhido como base naquele que tenha maior compatibilidade com o projeto para o qual o plano esteja sendo elaborado [Buckley, 1993]. Um exemplo pode ser encontrado no Padrão 828 da IEEE [IEEE Std 828,1998] que sugere que o plano seja dividido em seis classes de informação, como é mostrado no Quadro 3.1. 
Quadro 2: Configuração de Software: Classes de Informação

\begin{tabular}{|l|l|}
\hline Classe de Informação & Descrição \\
\hline Introdução & $\begin{array}{l}\text { Descreve o propósito do plano, escopo da aplicação, } \\
\text { termos chaves e referências. }\end{array}$ \\
\hline GCS Gerenciamento & $\begin{array}{l}\text { Quem?) Identifica as responsabilidades e autoridades } \\
\text { para realizar as atividades planejadas. }\end{array}$ \\
\hline GCS Atividades & $\begin{array}{l}\text { (O que?) Identifica todas as atividades para serem } \\
\text { executadas na aplicação do projeto. }\end{array}$ \\
\hline GSC Prazos & $\begin{array}{l}\text { Quando?) Identifica a coordenação necessária das } \\
\text { atividades do GCS com as outras atividades no projeto. }\end{array}$ \\
\hline GSC Recursos & $\begin{array}{l}\text { Como?) Identifica ferramentas e recursos físicos e } \\
\text { humanos para a execução do plano. }\end{array}$ \\
\hline GSC Manutenção do Plano & Identifica como o plano será mantido atualizado. \\
\hline
\end{tabular}

\section{Identificação da Configuração}

Durante esta atividade, um esquema é estabelecido para a identificação dos itens e as suas versões a serem controlados. É estabelecida a maneira como os itens são selecionados e a maneira como serão arquivados e recuperados do repositório.

Geralmente, estão sob o gerenciamento de configuração os itens mais utilizados no ciclo de vida, os mais genéricos, mais importantes para a segurança, os projetados para reuso e os que podem ser modificados por vários desenvolvedores ao mesmo tempo [Berlack, 1992].

Para cada item de configuração de software e suas versões, deverão ser identificados: a documentação que estabelece as linhas de referência; as referências de versão e outros detalhes de identificação. 


\section{Controle de Configuração}

O controle de configuração abrange: a identificação e registro das requisições de alterações; as análises e avaliações das alterações; a aprovação ou desaprovação das requisições; a implementação, verificação, e entrega do item de software modificado; o controle e auditoria de todos os acessos aos itens de configuração que lidam com funções de segurança crítica.

\section{Relato da Situação da Configuração}

O objetivo é relatar a todas as pessoas envolvidas no desenvolvimento e manutenção do software informações sobre as alterações na configuração do software.

Registros de gerenciamento e relatórios que apontam a situação e o histórico de controle de itens de software incluindo as linhas de referência devem ser preparados. E devem incluir: o número de mudanças de um projeto, o responsável pelas alterações, o que e quando aconteceu, e o que será afetado; as últimas versões do item de software, identificadores de liberação, número de liberações, e comparação entre as liberações.

\section{Avaliação da Configuração}

Deve ser determinado e garantido a integridade funcional, de acordo com os seus requisitos, e a integridade física dos itens de configuração.

Para assegurar que alterações foram implementadas de maneira apropriada há o suporte de dois tipos de avaliações: avaliação funcional que compreende uma verificação técnica formal na configuração do software e a avaliação física que consiste em verificar se a configuração está composta da versão mais recente dos itens de configuração determinados para a fase específica do ciclo de vida. 


\section{Gerenciamento de Liberação e Entrega}

Devem ser formalmente controladas a liberação e a entrega dos produtos de software e a documentação. Cópias principais de código e documentação devem ser mantidas por toda a vida do produto, e se conterem funções críticas de segurança, devem ser armazenados, empacotados e liberados de acordo com as políticas das organizações envolvidas.

\subsubsection{GARANTIA DE QUALIDADE}

Segundo a Norma ISO/IEC 12207, o processo de Garantia de Qualidade de Software é um processo para fornecer garantia adequada de que os produtos de software e os processos do ciclo de vida estejam de acordo com os requisitos especificados e com os planos estabelecidos.

A Garantia de Qualidade de Software necessita de liberdade organizacional e autoridade das pessoas diretamente responsáveis pelo desenvolvimento do produto de software ou pela execução do processo no projeto. Garantia de Qualidade pode ser interna ou externa, dependendo das evidências de qualidade do processo e/ou do produto demonstrada pelo fornecedor ou o adquirente. Faz uso de resultados de outros processos de apoio, tais como Verificação, Validação, Revisões, Auditorias e Resolução de Problema.

Desde o início do projeto de software, é necessário um grupo especializado em garantia de qualidade para estabelecer planos, padrões e procedimentos que irão satisfazer as restrições do projeto e as políticas da organização. O grupo de garantia de qualidade apóia as atividades relacionadas a garantir que tais planos, procedimentos e padrões sejam adequados às necessidades do projeto.

Este processo compreende a seguintes de atividades:

1) Implementação do Processo;

2) Garantia do Produto;

3) Garantia do Processo;

4) Garantia dos Sistemas de Qualidade. 


\section{Implementação do Processo}

Nesta atividade é estabelecido um processo de garantia de qualidade adequado ao projeto que tem o objetivo de assegurar que os produtos de software e os processos estejam de acordo com os requisitos e aderentes aos planos estabelecidos.

Também é necessário desenvolver um plano para conduzir as atividades e tarefas envolvidas no processo de garantia. O plano deve ser documentado, implementado e mantido durante a vigência do contrato e incluir:

- padrões de qualidade, metodologias, procedimentos e ferramentas para a realização das atividades de garantia de qualidade;

- procedimentos para revisões contratuais e a forma de coordenação de tais procedimentos;

- procedimentos para identificação, coleta, preenchimento, manutenção e disposição de registros de qualidade;

- recursos, cronogramas e responsabilidades para condução das atividades de qualidade;

- atividades e tarefas selecionadas dos processos de apoio, tais como verificação, validação, revisões, auditorias e resolução de problemas.

O Plano desenvolvido para conduzir as atividades de Garantia de Qualidade deve garantir cobertura adequada para o desenvolvimento de qualquer item de software. Como preparar um plano de Garantia de Qualidade de Software pode ser encontrado no Padrão 730 da IEEE [IEEE Std 730, 2002].

\section{Garantia do Produto}

Consiste nas seguintes tarefas:

- Assegurar que todos os planos requeridos pelo contrato sejam documentados, de acordo com o especificado, mutuamente consistentes e sejam executados como previsto; 
- Assegurar que os produtos de software e a documentação relacionada estejam de acordo com o contrato e com os planos;

- Na preparação para a entrega dos produtos de software, garantir que eles satisfaçam, plenamente, os requisitos contratuais e sejam aceitos pelo adquirente.

\section{Garantia do Processo}

Esta atividade deve garantir que:

- Os processos do ciclo de vida do software (fornecimento, desenvolvimento, operação, manutenção, e os processos de apoio, incluindo o de garantia de qualidade) empregados no projeto estejam de acordo com o contrato e aderente aos planos;

- As práticas internas de Engenharia de Software, o ambiente de desenvolvimento e de teste, e as bibliotecas utilizadas também estejam de acordo com o contrato;

- No caso de subcontratação, os requisitos sejam passados ao subcontratado e que os produtos produzidos pela subcontratação satisfaçam os requisitos do contrato original;

- O adquirente e as outras partes tenham suporte e cooperação necessários;

- As medições do produto e do processo de software estejam de acordo com padrões e procedimentos estabelecidos;

- A equipe designada para o projeto tenha habilidade e conhecimento necessários para entender e satisfazer os requisitos do projeto.

\section{Garantia dos Sistemas de Qualidade}

Segundo a Norma as atividades adicionais de gerenciamento de qualidade devem estar de acordo com as cláusulas da ISO 9001. 


\subsubsection{VERIFICAÇÃO}

De acordo com a Norma, o objetivo do Processo de Verificação é determinar se os produtos de uma atividade satisfazem os requisitos ou condições impostas à eles. O objetivo é assegurar que o software esteja sendo implementado corretamente.

Para diminuir custo e melhorar performance, o Processo de Verificação deve ser integrado aos processos que o utilizam (como fornecimento, desenvolvimento, operação, ou manutenção) o mais cedo possível. Este processo pode incluir análise, revisão e teste.

No caso em que o processo é executado por uma organização independente do fornecedor, desenvolvedor, operador ou manutenedor, o processo é chamado de Processo de Verificação Independente.

No processo são realizadas as seguintes atividades:

1) Implementação do Processo

2) Verificação

\section{Implementação do Processo}

Esta atividade aborda os aspectos relativos a implementar, documentar e executar um plano de Verificação. O plano deve tratar cada tarefa de verificação e relacionar recursos, responsabilidades e prazos.

Se um projeto justifica um esforço de verificação, os requisitos do projeto devem ser analisados em termos de:

- Potencial de um erro não detectado no sistema ou num requisito de software de causar morte ou dano pessoal, falha na missão, perda de equipamento ou prejuízo financeiro;

- Maturidade dos riscos associados com a tecnologia em uso;

- Disponibilidade de fundos e recursos. 
No caso de uma verificação independente, deve ser garantido à organização responsável pela condução do processo, independência e autoridade para realizar as atividades.

Os problemas e não conformidades detectados na Verificação devem ser tratados no Processo de Resolução de Problemas. E os resultados das atividades devem ser disponibilizados para o adquirente e para as outras organizações envolvidas.

\section{Verificação}

Esta atividade é relativa à verificação propriamente dita. Consiste nas tarefas de verificação de alguns elementos. Cada um deve ser verificado de acordo com determinados critérios:

Contrato. Verifica se o fornecedor tem capacidade em satisfazer os requisitos; se os requisitos são consistentes e cobrem as necessidades dos usuários; se os procedimentos são adequados para manipular com mudanças de requisitos; e se os critérios e procedimentos de aceite estão de acordo com os requisitos.

Processo. Verifica se os requisitos de planejamento e o prazo do projeto estão adequados; se os processos selecionados para o projeto estão sendo implementados, executados como planejado e estão de acordo com o contrato; se os padrões, procedimentos e o ambiente para os processos são adequados; se o projeto é gerenciado e se os envolvidos possuem treinamento adequado.

Requisitos. Verifica se os requisitos do sistema são consistentes, factíveis e testáveis; se a alocação dos requisitos para itens de hardware, de software, e de operações é apropriada e de acordo com o critério de projeto e do contrato;

Projeto. Verifica se o projeto está correto e coerente com os requisitos; se ele implementa corretamente as sequências de eventos, entradas, saídas, interfaces, fluxo lógico, alocação de prazo e custo; e se o projeto implementa requisitos de segurança com métodos rigorosos. 
Código. Verifica se o código está de acordo com os requisitos do projeto; se é testável e está correto, e de acordo com os requisitos e os padrões de codificação; se o código implementa corretamente as sequências de eventos, entradas, saídas, interfaces, fluxo lógico, alocação apropriada de prazo e custo; se o código selecionado pode ser derivado do projeto ou dos requisitos; se o código implementa requisitos de segurança exigidos por métodos rigorosos.

Integração. Verifica se os componentes e as unidades de software de cada item de software foram completa e corretamente integrados; se os itens de software, os itens de hardware e as operações manuais no sistema foram completa e corretamente integrados no sistema; e se as tarefas de integração são executadas de acordo com o plano de integração.

Documentação. Verifica se a documentação está adequada, completa e consistente; se sua preparação está no prazo; e se o gerenciamento de configuração dos documentos segue os procedimentos especificados.

\subsubsection{VALIDAÇÃO}

De acordo com a Norma, Validação é um processo para determinar se os requisitos e o produto final, sistema ou software, atendem ao uso específico proposto. O objetivo é assegurar que o software que está sendo desenvolvido é o software correto de acordo com os requisitos do usuário.

Este processo pode ser executado com vários graus de independência. Se o processo é executado por uma organização independente do fornecedor, desenvolvedor, operador, ou manutenedor, é chamado de Processo de Validação Independente [ISO/IEC 12207, 1995].

Das atividades de Validação, a atividade de Teste é considerada essencial para garantir qualidade ao software. O Teste é relevante para identificação e eliminação de erros, sendo usado para fornecer evidências da confiabilidade do software em complemento a outras atividades, como uso de revisão e verificação [Maldonado, 1991]. O Teste pode e deve ser aplicado desde as atividades iniciais do processo de desenvolvimento de software. 
O processo implica nas seguintes atividades:

1) Processo de Implementação.

2) Validação

\section{Processo de Implementação}

Esta atividade aborda aspectos relativos a implementar, documentar e executar o plano de Validação. O plano deve incluir: os itens de validação; tarefas de validação; recursos, responsabilidades e prazo; procedimentos para criar relatórios de validação para o adquirente e outras partes.

No caso de um esforço independente, deve ser assegurado à organização responsável por conduzir a Validação independência e autoridade para realizar as tarefas.

Os problemas e não conformidades detectados pela Validação devem ser tratados no Processo de Resolução de Problemas. Os resultados das atividades devem ser disponíveis para o adquirente e outras organizações envolvidas.

\section{Validação}

Esta atividade é relativa à validação propriamente dita, e consiste nas seguintes tarefas:

- Preparar e selecionar requisitos de teste, casos de teste e especificações de teste para analisar os resultados do teste;

- Conduzir os testes;

- Validar se o produto de software satisfaz seu uso pretendido;

- Testar o produto de software de forma apropriada em áreas reservadas do ambiente de uso. 


\subsubsection{REVISÃO CONJUNTA}

Revisão Conjunta é um processo para avaliar se a situação e os produtos de uma atividade de um projeto são apropriados. O objetivo é assegurar que o produto produzido possui qualidade suficiente para ser utilizado pelo seu usuário. As revisões são tanto no nível técnico quanto no nível de gerenciamento de projeto.

Consiste das seguintes atividades:

1) Implementação do Processo;

2) Revisões de Gerenciamento de Projeto;

3) Revisões Técnicas

\section{Implementação do Processo}

As seguintes tarefas compõem a atividade:

- Qualquer parte pode solicitar revisões ad hoc. Revisões periódicas podem ser mantidas, se for especificado no plano de projeto.

- Os recursos requeridos pela revisão, tais como, pessoas, ambiente, facilidades, hardware, software e ferramentas, devem ser acordadas pelas partes. Assim como os itens de cada revisão: agenda de reuniões, produtos de software (resultados de uma atividade) e problemas a serem revisados; escopo e procedimentos; e critérios de entrada e saída para a revisão.

- Os resultados são documentados e distribuídos. Os problemas detectados durante as revisões são registrados e tratados no processo de Resolução de Problemas. As partes devem concordar com os resultados da revisão e com quaisquer responsabilidades e critérios.

\section{Revisão de Gerenciamento de Projeto}

A revisão de gerenciamento é uma avaliação formal de um plano ou situação do projeto. A situação do projeto é avaliada em relação aos planos, prazos e padrões. 
O resultado da revisão de gerenciamento deve ser usado para:

- Que o progresso das atividades estejam de acordo com os planos, baseando-se numa avaliação do produto e da atividade;

- A manutenção do controle global do projeto através de alocação adequada de recursos;

- A mudança na direção do projeto ou a determinação da necessidade de um planejamento alternativo;

- A avaliação e gerenciamento de questões de risco.

A necessidade para conduzir uma determinada revisão de gerenciamento é estabelecida num apropriado documento de planejamento de projeto ( por exemplo Plano de Garantia de Qualidade, Plano de Desenvolvimento de Software, Plano de Validação ou Verificação). A conclusão de um elemento específico de software (por exemplo, Documentos de Planejamento, Especificação de Requisitos, Documento de Projeto ou Especificação de Código) pode ser o ponto de partida para uma revisão de gerenciamento [IEEE Std 1028, 1988].

\section{Revisões Técnicas}

A revisão técnica é uma avaliação formal de produtos ou serviços de software.

Fornece evidências que produtos e serviços em consideração estão: completos, no prazo, de acordo com seus padrões e especificações e prontos para próxima atividade; as mudanças foram implementadas corretamente e afetam apenas aquelas áreas identificadas no processo de Gerenciamento de Configuração; e que o desenvolvimento, operação ou manutenção estão sendo conduzidos de acordo com os planos, padrões e diretrizes do projeto.

Uma revisão técnica estará completa quando todas as questões identificadas na declaração dos objetivos da revisão forem tratadas e os relatórios das revisões forem emitidos. 


\subsubsection{AUDITORIA}

O objetivo da Auditoria é fornecer uma confirmação objetiva da conformidade dos produtos e processos aos planos, requisitos e contrato. É empregado por duas partes, onde uma (parte de auditoria) "audita" os produtos de software ou atividades de outra parte (parte auditada).

Auditorias são executadas de acordo com planos e procedimentos. Um plano de auditoria estabelece um procedimento para conduzir a auditoria e as ações a serem tomadas dependendo dos resultados [IEEE Std 1028, 1988]. Os auditores avaliam os produtos de software e os processos em relação aos critérios de auditoria, tais como contratos, especificações, procedimentos e padrões.

O processo é definido pelas seguintes atividades:

1) Implementação do Processo

2) Auditoria

\section{Implementação do Processo}

As seguintes tarefas são realizadas nesta atividade:

- A auditoria deve ser mantida até o momento pré-determinado no plano de projeto.

- Os auditores não devem ter nenhuma responsabilidade direta pelos produtos ou atividades a qual auditam.

- Os recursos necessários para conduzir a auditoria devem acordados pelas partes. O que inclui pessoal de suporte, locação, facilidades, hardware, software e ferramentas. As partes também devem concordar com os itens de cada auditoria: agenda; produtos e resultados de atividades a serem revisados; escopo e procedimentos; e critério de entrada e saída para auditoria.

- Os resultados da auditoria são documentados e fornecidos à parte auditada que reconhece (se for o caso) os problemas encontrados, os registra e relata para o Processo de Resolução de Problemas. 


\section{Auditoria}

Nesta atividade a auditoria é conduzida. Seu objetivo é garantir que: os produtos de software reflitam a documentação do projeto; a revisão e requisitos de teste prescritos pela documentação são adequados para o aceite dos produtos de software; os dados de teste estão de acordo com a especificação; os produtos de software foram sucessivamente testados e estão de acordo com suas especificações; os relatórios de teste estão corretos e as discrepâncias entre o resultado atual e o esperado foram resolvidos; as atividades foram conduzidas de acordo com requisitos, planos e contrato; e os custos e prazos estão de acordo com o plano estabelecido.

\subsubsection{RESOLUÇÃO DE PROBLEMAS}

De acordo com a Norma, este processo tem o objetivo de analisar e resolver os problemas, qualquer que seja a natureza e fonte, que são encontrados durante $o$ desenvolvimento, operação, manutenção ou outros processos, enfim durante todo o ciclo de vida do software. Provê prazos, responsabilidades e meios documentados para garantir que todos os problemas sejam analisados e resolvidos, e tendências dos problemas sejam reconhecidas e analisadas.

As seguintes atividades são necessárias:

1) Implementação do Processo;

2) Resolução de Problemas.

\section{Implementação do Processo}

O processo de Resolução de Problemas deve ser estabelecido para tratar todos os problemas detectados nos produtos de software e nas atividades. O processo deve estar de acordo com os seguintes requisitos:

a) Os problemas detectados devem ser prontamente relatados para o processo de Resolução de Problemas. A ação é iniciada, as partes relevantes são avisadas; as causas são 
identificadas, analisadas e, se possível, eliminadas; a resolução é arquivada e os registros dos problemas são mantidos.

b) Cada problema deve ser classificado por categoria e prioridade para facilitar as análises e a resolução do problema. Assim, é necessário um esquema para categorização e priorização de problemas.

c) As resoluções tomadas para os problemas encontrados também devem ser avaliadas. Verifica se os problemas foram resolvidos, se as tendências dos problemas foram revertidas e se as mudanças foram implementadas nos produtos e atividades apropriados. Determina se problemas adicionais tenham sido introduzidos durante a resolução dos problemas.

\section{Resolução de Problema}

Quando problemas forem encontrados num produto ou numa atividade, um relatório dever ser feito para descrever os problemas detectados. As resoluções são tomadas de acordo com os requisitos acima descritos: da detecção do problema, passando pela investigação e análise até a resolução do problema e de suas causas.

\subsection{CONSIDERAÇÕES FINAIS}

A estrutura da Norma foi concebida de maneira a ser flexível, modular e adaptável para uma organização, projeto ou aplicação. Uma organização, dependendo do seu propósito, pode selecionar e adaptar os processos às suas necessidades.

Neste capítulo foram apresentados os Processos de Apoio da Norma que servirão como base para a elaboração do trabalho proposto. 


\section{CApítulo 4: Processos de Apoio AO DESENVOLVIMENTO DE Aplicações Web}

\section{1 CONSIDERAÇÕES INICIAIS}

A relevância econômica das aplicações Web aumentou a necessidade de controlar e melhorar sua qualidade. Como consequência, há uma grande demanda por métodos e ferramentas que garantam a qualidade das aplicações Web, principalmente aqueles que auxiliam os processos fundamentais de produção. Dessa forma, neste capítulo, são apresentados Processos de Apoio ao desenvolvimento de aplicações Web, adaptados à natureza dessas aplicações.

Tratam-se de versões iniciais de processos, a serem evoluídas ou instanciadas de acordo com o uso dos processos, os quais podem ser alterados devido à adequação a projetos específicos e/ou à realidade das pequenas empresas produtoras de softwares Web.

Os processos influenciam na qualidade do produto de software. Neste trabalho, o termo "produto" tem o significado estendido para abranger quaisquer artefatos que sejam saídas de quaisquer processos usados para construir o produto final de software. Exemplos de produtos incluem especificação da aplicação, especificação de requisitos para componentes, 
código fonte, relatórios de testes, etc. Práticas sólidas de Engenharia de Software requerem que produtos intermediários relevantes para a qualidade sejam checados durante o desenvolvimento e na sua evolução.

\subsection{Processos de Apoio ao DesenVolvimento de APLICAÇÕEs Web}

Os Processos de Apoio ao desenvolvimento de aplicações Web tem como objetivo principal garantir a qualidade dessas aplicações que será melhorada através do uso iterativo desses processos. Os processos estão definidos numa estrutura a ser seguida pelas empresas para pôr em prática as atividades necessárias para dar suporte ao desenvolvimento das aplicações.

Os processos foram concebidos observando as características das aplicações Web e suas influências sobre os processos apresentados pela Norma 12207. Características marcantes dessas aplicações, como evolução constante, relevância da apresentação estética, habilidades técnicas diversificadas da equipe de desenvolvimento e participação efetiva do cliente, foram levadas em consideração na geração dos processos.

A estrutura dos processos segue à utilizada pela Norma ISO/IEC 12207 que define os processos de apoio como aqueles que são executados ao longo da realização dos processos fundamentais e são responsáveis pelo sucesso do projeto.

A Norma apresenta oito processos de apoio. Neste trabalho, dois deles não foram considerados e dois novos processos foram introduzidos, visto que consideram-se particularidades do desenvolvimento de aplicações Web e que os processos são destinados às empresas de pequeno porte. A seguir são listadas as alterações realizadas para que se adequasse aos requisitos exigidos por este trabalho: 
O processo de Auditoria e Revisão não foram considerados visto que os processos aqui definidos são destinados a pequenas empresas que não contam com todos os papéis necessários. As atividades definidas no processo de Auditoria e Revisão são asseguradas pelos processos de Garantia de Qualidade, Verificação e Validação.

Foi acrescentado o processo Usabilidade. O objetivo é assegurar a qualidade da experiência do usuário com as aplicações Web.

Foi acrescentado o processo de Acompanhamento, que visa controlar o progresso das atividades e produtos.

A estrutura dos processos de apoio ao desenvolvimento de aplicações Web considerados neste trabalho são apresentados na Figura 4.

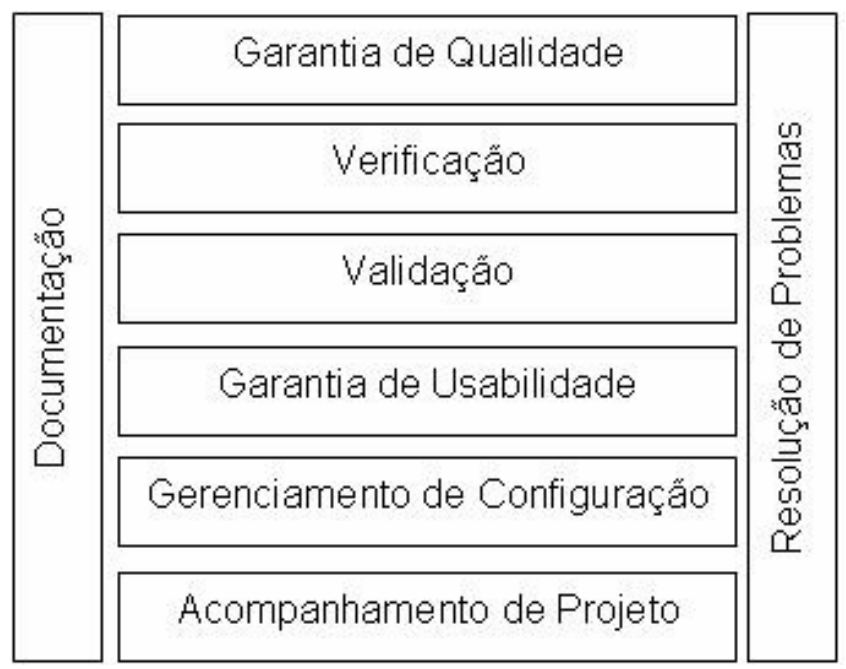

Figura 4: Processos de Apoio

Esses processos interagem tanto mutuamente quanto com os outros processos do ciclo de desenvolvimento necessários para a produção de aplicações Web. Cada processo pode envolver o esforço de um ou mais indivíduos ou grupo de indivíduos, que representam um papel ou vários papéis, dependendo das necessidades do projeto. De maneira geral, os processos ocorrem pelo menos uma vez em cada fase do desenvolvimento do projeto. 
Embora, os processos sejam apresentados com interfaces bem definidas, na prática eles podem sobrepor-se e interagir de formas não especificadas neste trabalho.

\subsection{AS ATIVIDADES DOS PROCESSOS}

Cada processo é composto por um conjunto de atividades que por sua vez é composta de tarefas. Uma tarefa representa a menor unidade que deve ser efetuada para a realização do processo do qual faça parte. Para algumas tarefas são apresentadas considerações que são utilizadas para explicar ou exemplificar necessidades específicas dos projetos Web.

Para facilitar a compreensão das atividades foi definida, através de três templates, uma estrutura básica padrão de apresentação das informações que é comum aos processos propostos e que permite que os aspectos relevantes das atividades sejam exibidos de forma semelhante. E também o primeiro parágrafo de cada tópico que descreve um processo ou atividade apresenta a definição do respectivo processo ou da atividade.

Os templates são apresentados em Figura 5, Figura 6 e no Quadro 3.

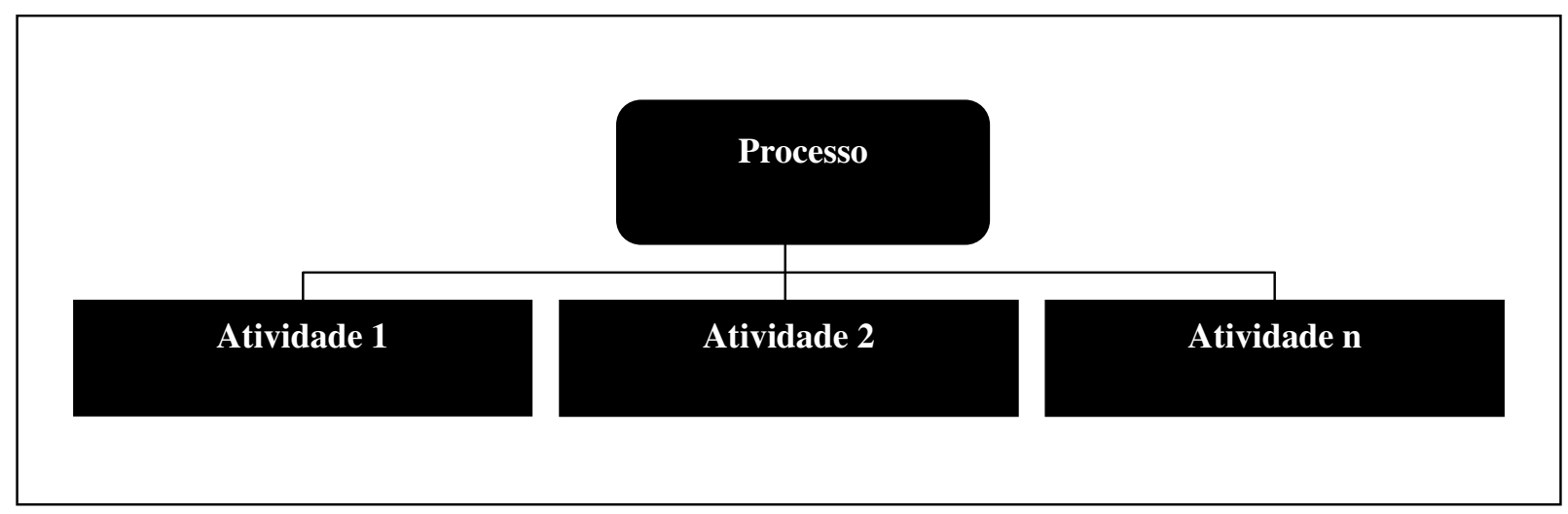

Figura 5: Template de Processos

Esse template é utilizado para apresentar as atividades que compõem o processo. 

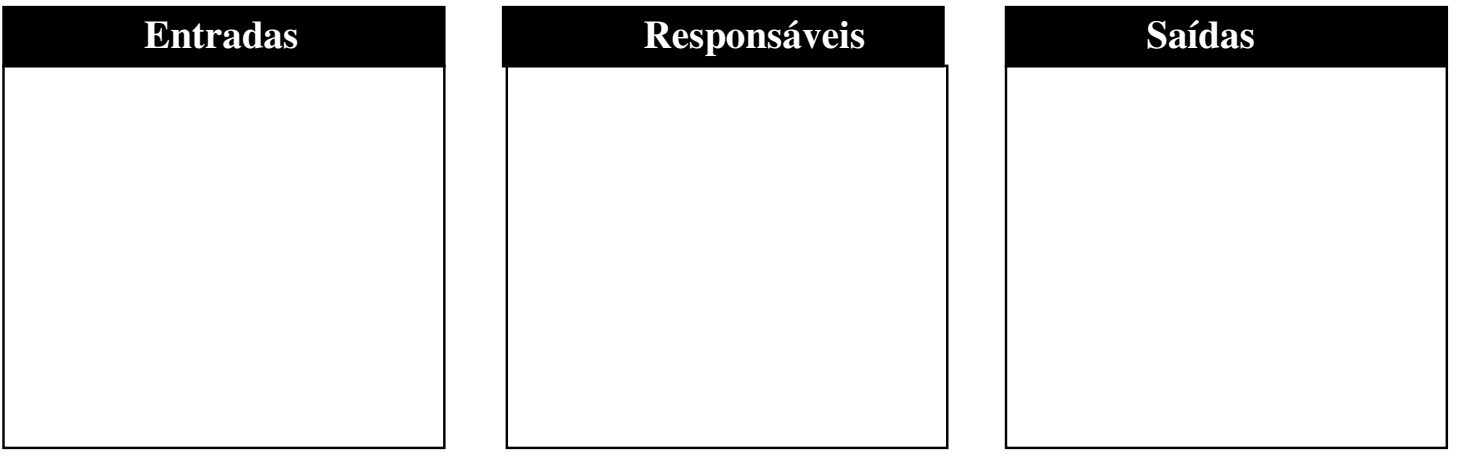

Figura 6 Template da Atividade: Artefatos de Entrada e Saída e Responsáveis.

No campo Responsáveis são descritos os papéis envolvidos na execução da atividade em questão. No campo Entradas são apresentados os produtos necessários para a execução da atividade e no campo Saídas os produtos produzidos na atividade e que podem servir de entrada para outras atividades.

Quadro 3:Template de tarefas das atividades

\begin{tabular}{|l|l|}
\hline Atividade & \\
\hline Meta & \\
\hline Tarefas & \\
& \\
\hline
\end{tabular}

De acordo com o Quadro 3, o campo Atividade indica o nome da atividade a ser executada, o campo Meta apresenta a finalidade da atividade e o campo Tarefas indica as tarefas necessárias para a completa execução da atividade. Quando necessário, para maiores explicações, são apresentadas Considerações para a tarefa. As considerações podem ser exemplos, restrições, questões específicas no projeto Web não abordados nos sistemas tradicionais, ou seja, algum detalhamento que ilustre a tarefa. 
As tarefas são apresentadas segundo uma ordem considerada ideal para a condução da atividade, mas não é uma obrigação. As empresas podem alterá-las de acordo com a necessidade do momento e da fase em que se encontra o projeto, assim como deixar de realizar algumas que não são consideradas pertinentes a situação.

\subsubsection{PRINCÍPIOS BÁSICOS DOS PROCESSOS}

Os processos foram concebidos de maneira a serem flexíveis e adaptáveis às necessidades da empresa que os utilizam. Os processos se inter-relacionam e são baseados nos seguintes princípios básicos:

Modularidade. Um processo é dedicado a uma específica função. Os processos são fortemente relacionados com um mínimo de interfaces. Cada processo possui um conjunto de atividades e tarefas, refinadas o suficiente para serem executadas independentemente.

> Responsabilidade: Um processo é de responsabilidade de uma organização ou parte dela, sendo que se pode considerar como organização um indivíduo ou um grupo de indivíduos que representam os papéis. A determinação de responsabilidade assegura melhor aplicabilidade dos processos e diminui o risco de ocorrerem problemas.

$>$ Evolução. Os processos possuem a qualidade de serem evolutivos, ou seja, foram concebidos de uma forma que a cada interação/execução eles sejam alterados e adaptados às necessidades de cada empresa ou projeto Web. Podese ocorrer definição de outras atividades e tarefas, eliminação de algumas e até mesmo alteração na forma de utilização. Isso assegura melhoria contínua dos processos.

$>$ Flexibilidade. Os processos são destinados ao desenvolvimento de aplicações Web para quaisquer projetos dessa natureza produzidos por uma pequena empresa. Assim, os processos são especializados nas características dessas aplicações, mas são flexíveis para serem adaptados, sem restrições e maiores transtornos, de acordo com as particularidades de cada projeto Web. Durante a 
utilização dos processos características específicas do projeto e da organização devem ser levados em conta.

Independência. A utilização dos processos é independente do modelo de desenvolvimento de software adotado pela empresa. Os processos são baseados em fases genéricas do desenvolvimento de aplicações Web.

Atividades de Planejamento. Cada processo tem como primeira atividade o seu planejamento. Geralmente, o planejamento é realizado uma vez para estabeceler a estrutura organizacional do processo, sendo alterado de acordo com as necessidades específicas de cada projeto. Os planos, gerados nas respectivas atividades de planejamento de cada projeto, podem ser formal ou informal, servem como diretrizes para a execução do processo.

\subsubsection{PAPÉIS}

Para pôr em prática as atividades e tarefas dos Processos de Apoio ao desenvolvimento de aplicações Web definidos neste trabalho, um conjunto de papéis são considerados. Um papel é uma função ou conjunto de funções desempenhadas por um indivíduo com um determinado objetivo e que produz um resultado dentro de um projeto. Um papel define responsabilidades assumidas no processo, estando relacionado a atividades e produtos. Um papel pode ser desempenhado por um indivíduo ou um grupo de indivíduos, e o mesmo indivíduo pode desempenhar mais de um papel no mesmo projeto ou em projetos diferentes.

De acordo com este trabalho, os profissionais necessários para os processos de apoio ao desenvolvimento de aplicações Web estão associados aos seguintes papéis:

Gerente do projeto: gerencia os processos, as pessoas e lida com o cliente num determinado projeto. Suas responsabilidades envolvem o planejamento, distribuição das tarefas, acompanhamento dos processos e pessoas. Para os 
projetos Web são necessários conhecimentos nas áreas de tecnologia, criação visual e hipermídia.

Arquiteto de software: responsável pela solução técnica do software. Estabelece a arquitetura e os componentes a serem utilizados. Assim como define e aplica as normas de software.

Diretor de criação: responsável pela área de criação visual e usabilidade, ou seja, pela experiência do usuário com a aplicação.

Engenheiro de Qualidade Web: responsável em definir, executar e verificar as atividades relacionadas com o controle de qualidade do produto e dos processos.

Gerente de Configuração: controla os itens que estão sob Gerenciamento de Configuração.

Arquiteto da informação: responsável pela organização da informação nas páginas da aplicação Web, de forma que os usuários a encontrem de forma fácil e eficiente.

$>$ Web designer: responsável pelo projeto da identidade visual da aplicação.

Testador: responsável pelos testes da aplicação, o que inclui os aspectos funcionais, de integração, de desempenho e de navegabilidade.

Outros papéis são desempenhados durante o ciclo de desenvolvimento do projeto, como redatores, Web master, editores, programadores, engenheiro de requisitos, analista de sistemas, etc. Porém, foram apresentados, somente, aqueles necessários nos Processos de Apoio aqui definidos. 


\subsubsection{GARANTIA DE QUALIDADE}

Definição: Garantia de Qualidade é o processo que inclui as atividades necessárias para garantir que os produtos e os processos num projeto estejam de acordo com os requisitos especificados.

Existem várias razões para tratar da qualidade de uma aplicação Web. O crescimento do comércio eletrônico, por exemplo, tem tornado o sucesso de uma empresa mais dependente da qualidade desse tipo de aplicação. Para cada aplicação Web, não obstante a sua missão e objetivo, o competidor está a um link próximo, por isso atrair e manter o usuário tornou-se essencial [Mich et al, 2003].

A ISO define qualidade de um dado produto como " a totalidade das características de uma entidade - produtos ou serviços - que exercem suas habilidades para satisfazer as necessidades declaradas ou implícitas" [ISO 8402,1994]. De acordo com essa definição, qualidade está relacionada com a conformidade dos requisitos. Dessa forma, o primeiro tópico de um processo de garantia de qualidade é a descrição da qualidade do produto requerida e as características relacionadas a ela. Assim, uma aplicação Web com alta qualidade é aquela que atende aos requisitos de qualidade do usuário e aos requisitos de qualidade do cliente.

A noção de qualidade não é simples, existem muitos atributos ${ }^{2}$ de qualidade relevantes a um projeto particular. Por isso, é preciso antes de tudo determinar o real propósito da aplicação, mantendo um ponto básico em mente: as necessidades do cliente e do usuário devem ser consideradas primeiramente, e incluem diversas características de qualidade, não apenas a funcionalidade, mas, principalmente, as que combinam aspectos artísticos e gráficos com funcionalidades do produto. Esses aspectos são difíceis de medir e especificar, tais como qualidade visual, estética da marca da empresa, apresentação de conteúdo, organização da informação, etc.

Ressalta-se que este processo não lida com modelos e critérios que avaliam as capacidades das empresas em produzir Aplicações Web, ou seja, não tem a intenção de certificação da empresa em relação a qualidade dos processos.

\footnotetext{
${ }^{2}$ A definição de atributo utilizada é a mesma que se refere a Norma 9126
} 
A Figura 7 apresenta as atividades do processo.

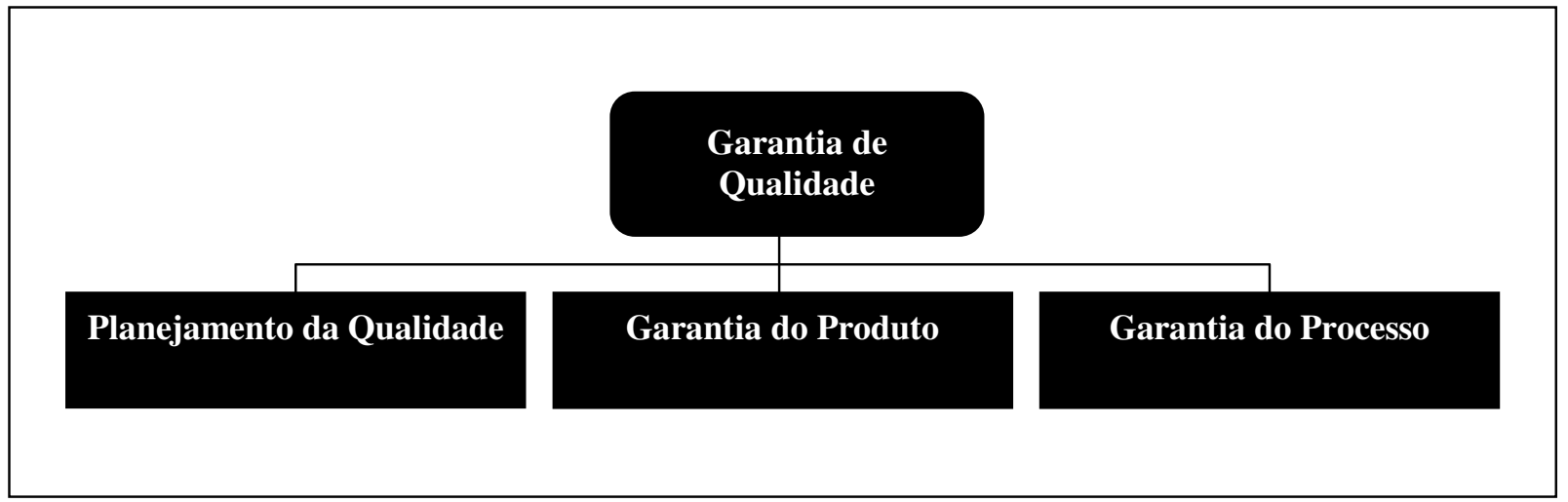

Figura 7 Atividades de Garantia de Qualidade

\section{Planejamento da Qualidade}

Definição: Nesta atividade, é estabelecido o processo, através da identificação de atividades e padrões que são relevantes para a qualidade do projeto e determina-se como satisfazê-los.

É uma atividade chave que deve ser executada de forma regular e em paralelo com as atividades de planejamento de projeto, pois a qualidade desejada pode exigir uma análise mais detalhada do projeto e do risco de um problema identificado. A equipe do projeto deve estar ciente a um dos princípios fundamentais da garantia de qualidade: a qualidade é planejada, não inspecionada.

A Figura 8 apresenta as entradas, responsáveis e saídas da atividade.

\begin{tabular}{|c|c|c|}
\hline Entradas & Responsáveis & Saídas \\
\hline $\begin{array}{l}\text { - Políticas de qualidade } \\
\text { - Requisitos do projeto } \\
\text { - Saídas de outros processos }\end{array}$ & $\begin{array}{l}\text {-Engenheiro de qualidade } \\
\text { Web } \\
\text {-Gerente de projeto }\end{array}$ & $\begin{array}{l}\text { - Plano de garantia de } \\
\text { qualidade } \\
\text { - Checklists } \\
\text { - Entrada para outros } \\
\text { processos }\end{array}$ \\
\hline
\end{tabular}

Figura 8: Planejamento de Qualidade: artefatos e responsáveis. 
Entradas para o Planejamento de Qualidade:

- Políticas e padrões de Qualidade: são as intenções ou procedimentos globais da organização em relação à qualidade. Se faltarem políticas formais de qualidade na empresa, a equipe de gerenciamento do projeto e de qualidade devem desenvolver suas próprias políticas de qualidade;

- Requisitos do projeto ou escopo do projeto: documentam os objetivos do projeto, a descrição do produto e os principais subprodutos que servem para definir importantes requisitos de qualidade, questões técnicas e outros aspectos;

- Saídas de outros processos: processos de outras áreas podem produzir saídas que devem ser consideradas no planejamento de qualidade. Por exemplo: algum processo que gerencia a terceirização de serviço.

Responsáveis:

- Engenheiro de Qualidade Web: possui o conhecimento de procedimentos e atividades da organização para assegurar a garantia de qualidade do projeto Web, assim como as necessidades específicas para esse tipo de aplicação.

- Gerente do Projeto: identifica os atributos de qualidade necessários para cumprir os requisitos impostos pelo projeto. Atua com o Engenheiro de Qualidade Web para identificar as relações existentes entre as atividades envolvidas para a garantia de qualidade e as atividades planejadas para o desenvolvimento da aplicação Web.

Saídas do Planejamento de Qualidade:

- Plano de Garantia de Qualidade: desenvolvido para conduzir as atividades e tarefas envolvidas no processo. Descreve responsabilidades, procedimentos, processos e recursos necessários para implementar o processo de garantia de qualidade.

- Checklist: contém itens para verificar se um conjunto de passos necessários está sendo executado. São importantes para garantir consistência nas atividades mais utilizadas.

- Entradas para outros processos: pode identificar a necessidade de atividades adicionais em outros processos.

O Quadro 4 apresenta as tarefas relacionadas a esta atividade. 
Quadro 4: Tarefas de Planejamento de Qualidade

\begin{tabular}{|c|c|}
\hline Atividades & Planejamento de Qualidade \\
\hline Meta & $\begin{array}{l}\text { Estabelecer uma estrutura organizacional para realizar atividades que garantam } \\
\text { a conformidade dos produtos e processos com os planos estabelecidos. }\end{array}$ \\
\hline Tarefas & $\begin{array}{l}\text { 1.Identificar atributos e padrões de qualidade da aplicação } \\
\text { Os atributos e os padrões identificados estão associados a um custo } \\
\text { que deve estar explícito ao cliente. Por exemplo, a segurança da } \\
\text { informação, de acesso, de servidores, etc podem ser definidas em } \\
\text { vários níveis de menor a maior risco. Os atributos estão relacionados } \\
\text { com as seguintes importantes características para aplicações Web: } \\
\text { usabilidade, funcionalidade, confiabilidade, eficiência e } \\
\text { mantenabilidade. } \\
\text { 2.Documentar políticas de qualidade da empresa desenvolvedora. } \\
\text { 3.Identificar normas de qualidade do cliente. } \\
\text { Toda aplicação Web possui uma marca (brand, em inglês) que a } \\
\text { identifica, a maioria das marcas estão associadas às empresas } \\
\text { clientes, que são utilizadas em outras mídias. Por exemplo, bancos, } \\
\text { lojas de departamento e aplicações institucionais. Assim, deve seguir } \\
\text { as políticas definidas pelo cliente para a utilização da marca. Do } \\
\text { mesmo modo, para o tipo de linguagem, cores e imagens e outras } \\
\text { normas. } \\
\text { 4.Definir atributos de qualidade de terceiros e a responsabilidade. } \\
\text { O desenvolvimento de aplicações Web, muitas vezes, envolve terceiros, } \\
\text { como provedores de acesso, provedores de conectividade, Web } \\
\text { services }{ }^{3} \text {, vídeos e outros componentes. } \\
\text { 5.Validar os atributos de qualidade com o cliente. } \\
\text { O desenvolvimento de aplicações Web é voltado ao cliente, que é parte } \\
\text { integrante do processo. } \\
\text { 6.Definir procedimentos para revisões contratuais. } \\
\text { 7.Selecionar atividades dos Processos de Verificação, Validação e Usabilidade } \\
\text { utilizados no processo. } \\
\text { 8.Definir procedimentos e ferramentas para a realização das atividades. } \\
\text { 9.Com as definições acima, gerar um plano de Garantia de Qualidade que deve } \\
\text { ser aprovado pelo gerente e distribuído para os envolvidos. }\end{array}$ \\
\hline
\end{tabular}

\section{Garantia do Produto}

Definição: Assegura que os produtos gerados durante o ciclo de vida da aplicação estejam de acordo com os planos estabelecidos e satisfaçam os requisitos.

\footnotetext{
${ }^{3}$ Web services: são aplicações de Internet baseadas em padrões abertos que permitem sua utilização por outras aplicações. Não foram considerados como uma aplicação Web, definido neste trabalho, pois, geramente, não envolvem interação com usuários.
} 
Os procedimentos definidos no plano de garantia de qualidade devem ser realizados ao longo do ciclo de desenvolvimento do projeto.

A Figura 9 apresenta as entradas, responsáveis e saídas pela atividade.

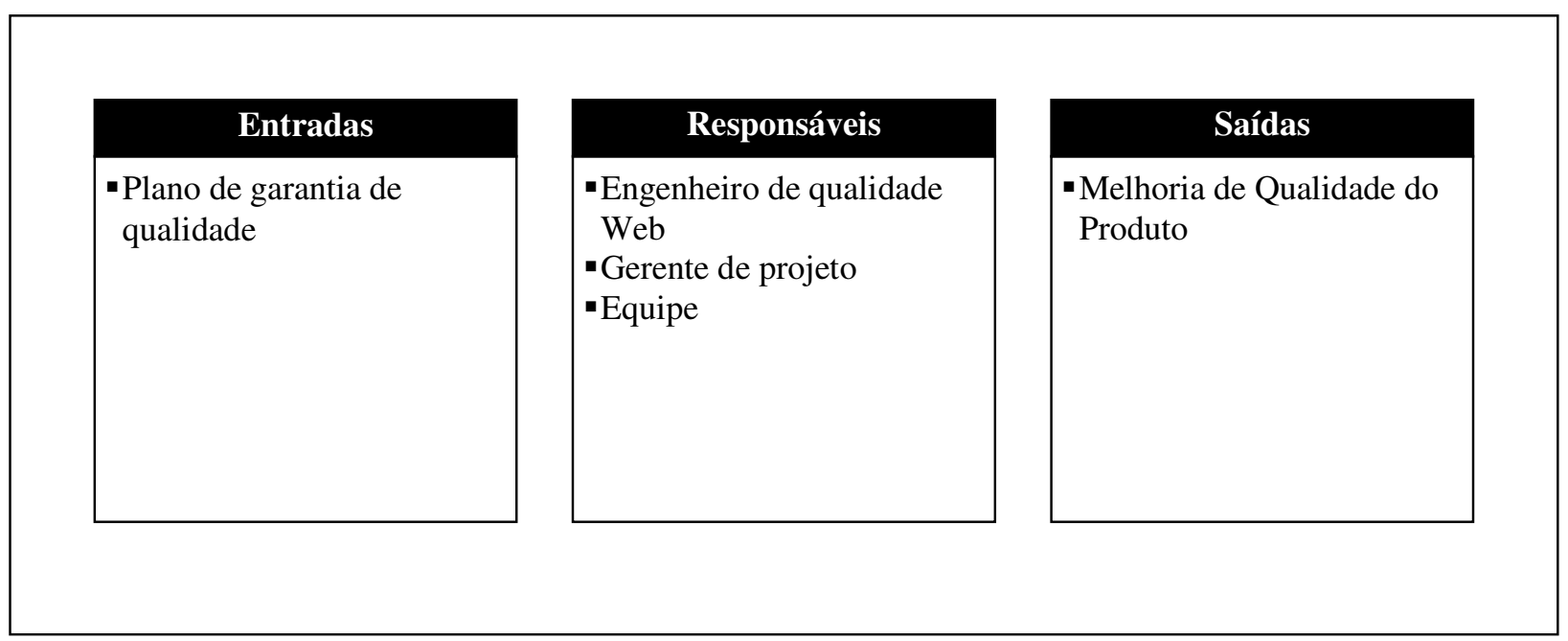

Figura 9: Garantia do Produto: artefatos e responsáveis.

Entradas para garantia de qualidade do produto:

- Plano de garantia de Qualidade: as políticas e procedimentos definidos para alcançar os requistos contratuais são implementados pela equipe durante o desenvolvimento.

Responsáveis:

- Engenheiro de Qualidade Web: atua na verificação de que os procedimentos de qualidade estejam sendo realizados e definem melhorias de qualidade

- Gerente de Projeto: assegura que o plano seja seguido pela equipe.

- Equipe: realizam as suas atividades de acordo com as definições do plano de garantia de qualidade para garantir qualidade de produto.

Saídas de garantia de qualidade de produto:

- Melhoria de qualidade do produto: aponta as falhas de qualidade do produto que não estejam de acordo com os requisitos contratuais. Inclui a tomada de ações para aumentar a efetividade do produto e a eficiência do projeto. 
O Quadro 5 apresenta as tarefas de Garantia de Produto.

Quadro 5: Tarefas de Garantia de Produto

\begin{tabular}{|c|l|}
\hline Atividade & Garantia do Produto \\
\hline Meta & $\begin{array}{l}\text { Os produtos gerados estejam de acordo com os padrões de qualidade } \\
\text { estabelecidos. }\end{array}$ \\
\hline Tarefas & $\begin{array}{l}\text { 1.Assegurar que os planos requeridos pelo contrato estejam documentados e } \\
\text { consistentes. } \\
\text { Questões como tratamento de imagem, edição de conteúdo, redação, } \\
\text { criação de logotipos, criação de vídeos, browsers compatíveis, } \\
\text { linguagens, etc devem, também, serem especificadas nos planos, para } \\
\text { não causarem dúvidas de contratação. } \\
\text { essegurar que os produtos e os documentos estejam de acordo com o contrato } \\
\text { As atividades dos processos de Verificação, Validação e Usabilidade } \\
\text { apoiam essa atividade. } \\
\text { 3.Garantir que os produtos satisfaçam os requisitos contratuais. } \\
\text { Além de funcionalidades, atributos relacionados com a experiência do } \\
\text { usuário com a aplicação, também, devem ter a devida atenção. } \\
\text { 4.Assegurar que a aplicação seja aceita pelo cliente. } \\
\text { No caso de desenvolvimento de protótipos, para esse também deve } \\
\text { existir um termo de aceite. }\end{array}$ \\
\hline
\end{tabular}

\section{Garantia do Processo}

Definição: Assegura que os processos utilizados durante o ciclo de vida da aplicação estejam de acordo com os planos estabelecidos, assim como o ambiente de desenvolvimento e teste. E que a equipe do projeto tenha habilidades necessárias para satisfazer os requisitos.

Como dito, o processo de garantia de qualidade não tem o objetivo de avaliar a capacitação da empresa em realizar os processos, essa atividade preocupa-se com a execução de acordo com o que foi definido para cada processo.

A Figura 10 apresenta as entradas, responsáveis e saídas da atividade. 


\section{Entradas}

- Plano de garantia de qualidade

- Checklists

\section{Responsáveis}

-Engenheiro de qualidade Web

- Gerente de projeto

-Equipe

\section{Saídas}

- Melhoria de Qualidade dos

Processos

- Checklists concluídas

Figura 10: Garantia do Processo: artefatos e responsáveis

Entradas para garantia do processo:

- Plano de garantia de Qualidade: descreve como a equipe do projeto deve realizar suas atividades de acordo com as normas de qualidade definidas.

- Checklist: os itens definidos no planejamento de qualidade são realizados.

Responsáveis:

- Engenheiro de Qualidade Web: atua na verificação de que as atividades estão sendo realizadas de acordo com os planos e definem melhorias de qualidade.

- Gerente de Projeto: assegura que as atividades definidas sejam realizadas pela equipe.

- Equipe: realizam as suas atividades de acordo com as definições do plano de garantia de qualidade para garantir qualidade do processo.

Saídas de garantia de qualidade de processo:

- Melhoria de qualidade do processo: aponta as falhas de execução dos processos. Os ajustes nos processos incluem a tomada de ações corretivas ou preventivas.

- Checklists concluídas: os checlists preenchidos devem fazer parte dos registros do projeto.

O Quadro 6 apresenta as tarefas de garantia de processo. 
Quadro 6: Tarefas de Garantia de Processo

\begin{tabular}{|c|c|}
\hline Atividade & Garantia do Processo \\
\hline Meta & Os processos do ciclo de vida estejam de acordo com os planos estabelecidos. \\
\hline Tarefas & $\begin{array}{l}\text { 1.Assegurar que os processos empregados no desenvolvimento e manutenção } \\
\text { do projeto estejam aderentes aos planos. } \\
\text { As atividades dos processos de Verificação apóiam essa tarefa. } \\
\text { 2.Assegurar que o ambiente de desenvolvimento e teste, bibliotecas utilizadas e } \\
\text { práticas internas de Engenharia de Web estejam de acordo com os planos. } \\
\text { 3. Assegurar que a equipe tenha os conhecimentos necessários para entender e } \\
\text { satisfazer os requisitos de projeto. } \\
\text { É necessária uma equipe com habilidades em diversas áreas - técnicas } \\
\text { e não técnicas - software, hardware, conectividade, artes gráficas e } \\
\text { marketing. Dependendo do momento e do tipo de projeto web, uma } \\
\text { especialidade é mais requisitada que a outra. } \\
\text { 4.Assegurar que as medições do produto e processo estejam de acordo com os } \\
\text { padrões estabelecidos. } \\
\text { A evolução contínua e a entrega imediata de funçôes exigem que os } \\
\text { processos sejam ágeis e flexíveis para garantir qualidade e rapidez. Por } \\
\text { isso, deve ser medido, também, o impacto que causam no projeto em } \\
\text { relação ao tempo que é necessário para executá-los. Processos } \\
\text { onerosos devem ser redefinidos. }\end{array}$ \\
\hline
\end{tabular}

\subsubsection{DOCUMENTAÇÃO}

Definição: Documentação é o processo que planeja, projeta, produz, edita, distribui e mantém os documentos necessários no projeto.

Características das aplicações Web como evolução contínua, urgência de entrega de funções e equipes multidisciplinares influenciam diretamente a documentação. Com mudanças constantes e rápidas nos requisitos da aplicação, a organização deve documentar essas alterações de forma consistente, porém de forma ágil para não prejudicar os prazos de desenvolvimento que são curtos, com mínimo de informações, mas o suficiente para o entendimento de toda equipe. 
Os documentos produzidos durante o desenvolvimento de aplicações Web incluem scripts, áudio, imagens e vídeo. Deve-se utilizar ferramentas adequadas para a documentação desse tipos de mídia. Novos tipos de documentos são produzidos, por exemplo, mapa navegacional que apresenta a hierarquia entre as páginas de forma estática; mapa relacional que além de apresentar a hierarquia entre as páginas vincula a documentação de toda a equipe e é uma referência de layout, de conteúdo e dos sistemas embutidos nas páginas; wireframes que é um esboço da interface das páginas.

Como a equipe é multidisciplinar, os documentos devem englobar as diferentes linguagens utilizadas pelos diferentes perfis de profissionais em um padrão que garanta o bom entendimento de todos os membros da equipe.

A Figura 10 apresenta as atividades do processo de Documentação.

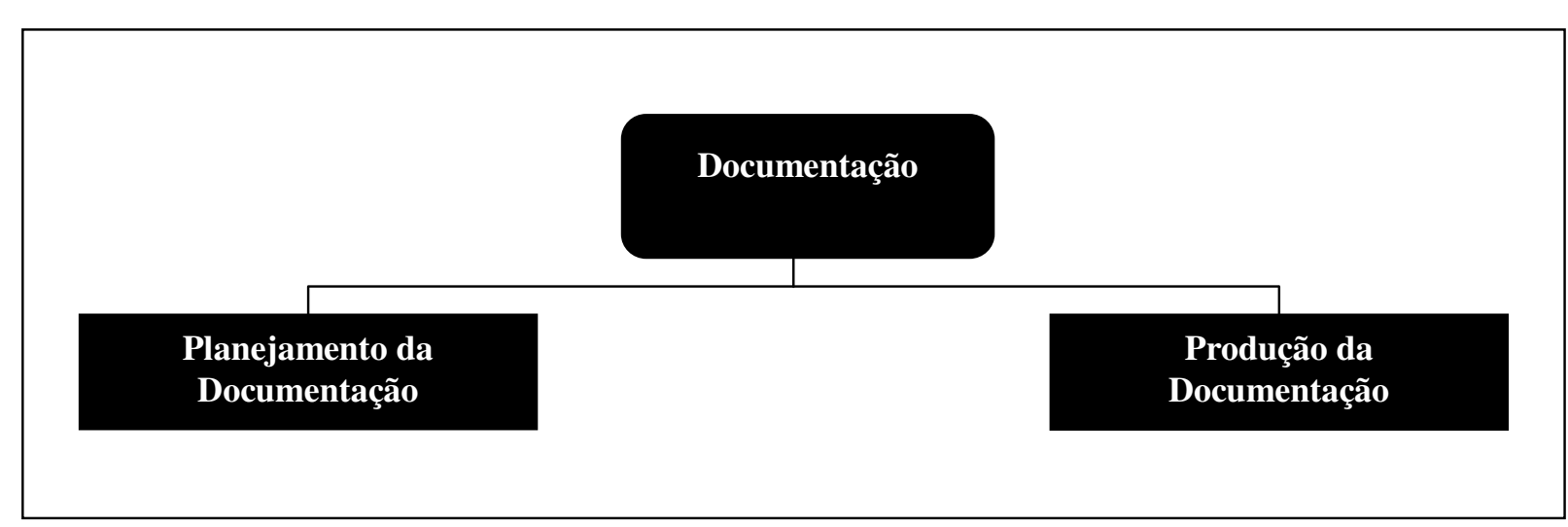

Figura 11: Atividades de Documentação

\section{Planejamento da Documentação}

Definição: consiste em desenvolver um plano que identifique os documentos que serão produzidos durante o ciclo de vida e que estabeleça os padrões para a produção e distribuição dos mesmos.

Os aspectos exigidos para a produção dos documentos são descritos, desde a estrutura interna até a apresentação para o usuário final. Cada documento deve ser projetado de acordo com os padrões estabelecidos.

A Figura 12 apresenta as entradas, responsáveis e saídas da atividade. 


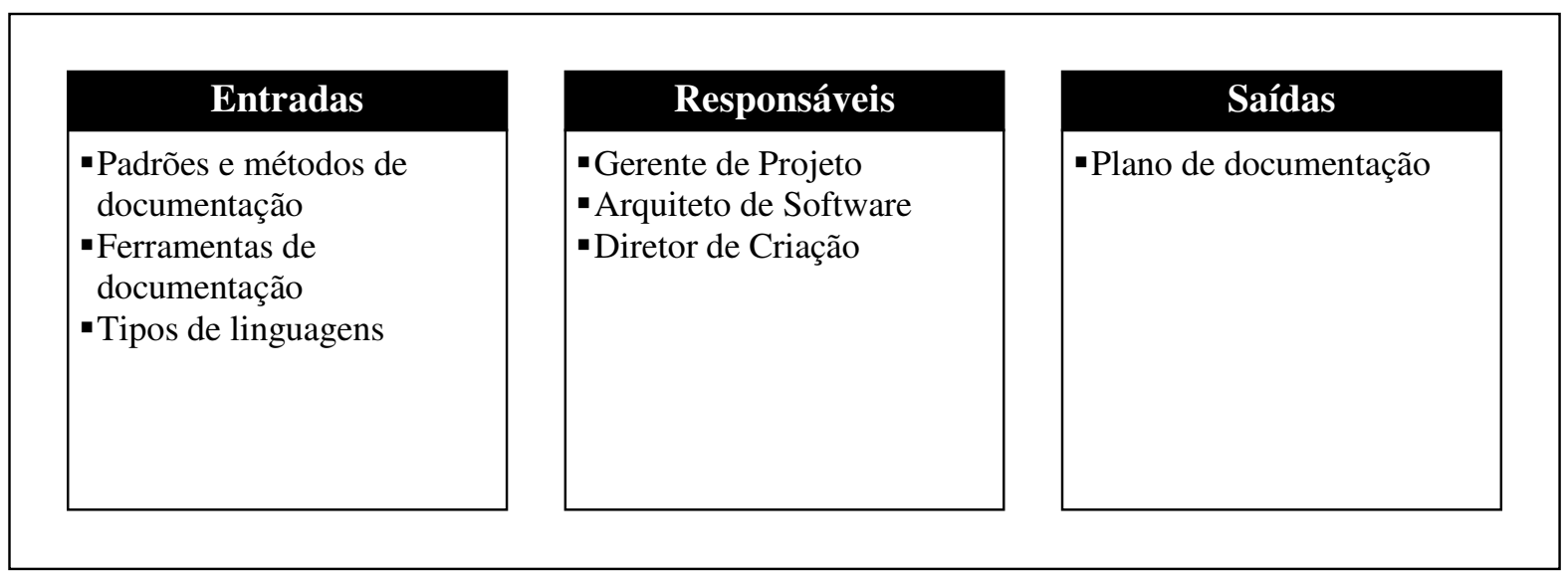

Figura 12: Planejamento de Documentação: artefatos e responsáveis

Entradas para o planejamento da documentação:

- Padrões e métodos de documentação: a empresa pode utilizar padrões e métodos de documentação existentes no mercado ou criar seus próprios de acordo com as suas necessidades.

- Ferramentas de documentação: devem ser documentadas quais ferramentas serão utilizadas para a produção de cada documento.

- Tipos de linguagens: deve ser especificado a linguagem de cada documento, como linguagens de programação para os códigos fontes, linguagem do modelo de dados, etc.

Responsáveis:

- Gerente de Projeto: identifica os documentos a serem produzidos, quais serão apresentados ao cliente e estabelece o cronograma para versões intermediárias e finais.

- Arquiteto de software: identifica os documentos técnicos que serão produzidos e as linguagens utilizadas; e estabelece a forma de desenvolvê-los e apresentálos.

- Diretor de criação: identifica os documentos de criação visual que serão desenvolvidos - mapas do site, mapa relacional, mapa navegacional, layout, desenhos, etc - e estabelece os padrões de como desenvolvê-los. 
Saídas do planejamento de documentação

- Plano ou diretrizes de documentação: é criado um plano de documentação com os aspectos estabelecidos para a produção e distribuição dos documentos.

O Quadro 7 apresenta as tarefas da atividade.

Quadro 7: Tarefas de Planejamento da Documentação

\begin{tabular}{|c|c|}
\hline Atividades & Planejamento da Documentação \\
\hline Meta & Gerar um plano de documentação para a produção de documentos. \\
\hline Tarefas & $\begin{array}{l}\text { 1.Identificar os documentos que serão produzidos. } \\
\text { Além de documentos técnicos, são identificados os documentos não } \\
\text { técnicos, como apresentação gráfica, mapas do site, imagens, } \\
\text { animação gráfica, etc } \\
\text { 2.Definir responsabilidades, procedimentos e ferramentas para o } \\
\text { desenvolvimento e manutenção dos documentos. } \\
\text { 3.Definir o relacionamento com as atividades do processo de Gerenciamento } \\
\text { de Configuração. } \\
\text { 4.Definir quais documentos serão apresentados para o cliente e como. } \\
\text { Os documentos apresentados para o cliente devem ter a linguagem, } \\
\text { estilo de apresentação e o nível de detalhes de acordo com a audiência } \\
\text { pretendida. Os principais documentados apresentados ao cliente estão } \\
\text { relacionados com a aprovação do levantamento dos requisitos, que } \\
\text { envolve além das funcionalidades a apresentação visual. } \\
\text { 5.Definir o relacionamento com as atividades de evolução/manutenção da } \\
\text { aplicação. } \\
\text { 6. Com as definições acima, gerar diretrizes de documentação. }\end{array}$ \\
\hline
\end{tabular}

\section{Produção da Documentação}

Definição: consiste em produzir e manter os documentos de acordo com o plano de documentação estabelecido.

Durante o desenvolvimento da aplicação Web são produzidas informações que dependendo de suas implicações no projeto, devem ser registradas pois servem de partida para as atividades dos processos. Os documentos principais são armazenados de acordo com os controles de Gerenciamento de Configuração.

A Figura 13 apresenta as entradas, responsáveis e saídas da atividade. 


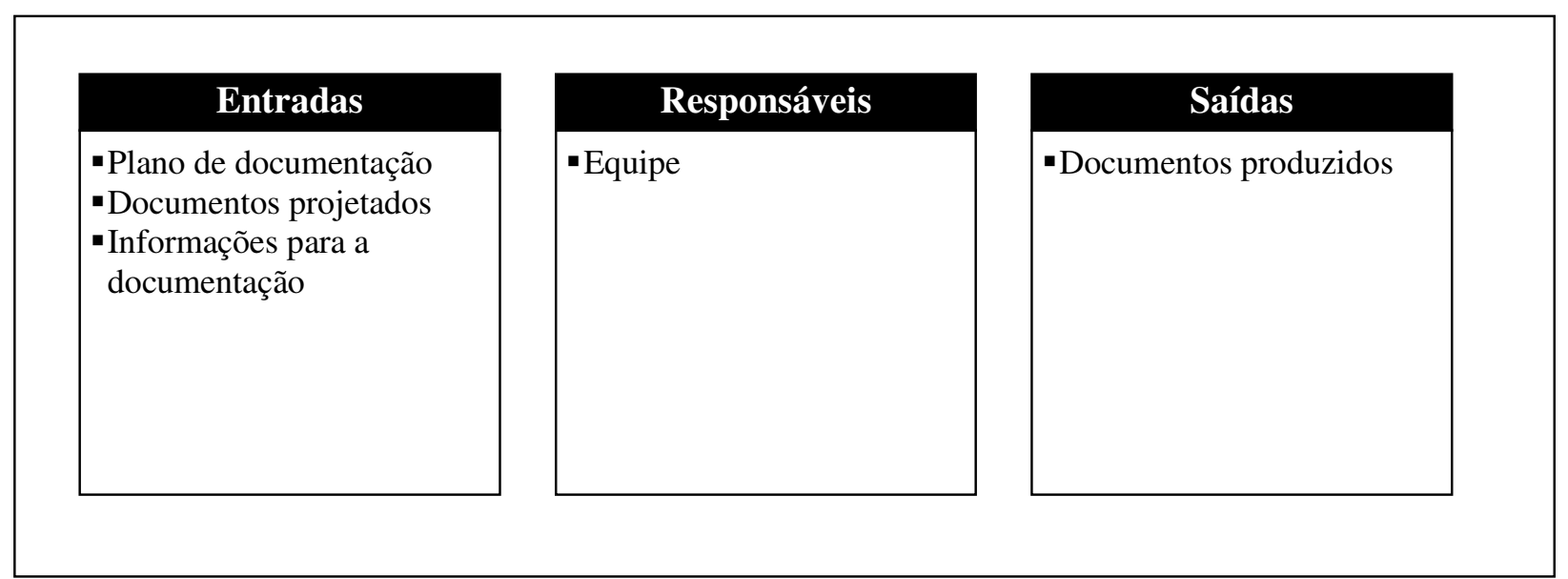

Figura 13: Produção da Documentação: artefatos e responsáveis

Entradas para a produção de documentação

- Plano de documentação: a produção dos documentos é realizada de acordo com os planos estabelecidos.

- Documentos projetados: os documentos projetados são a base para a produção dos mesmos e servem como modelos para outros projetos.

- Informações para a documentação: as informações que serão editadas nos documentos são produzidas durante todo o ciclo de vida da aplicação.

Responsáveis:

- Equipe: todos da equipe que produzem documentos.

Saídas:

- Documentos produzidos: documentos produzidos de acordo com o plano estabelecido, os documentos projetados e as informações para a sua edição.

O Quadro 8 apresenta as tarefas da atividade. 
Quadro 8: Tarefas da Produção da Documentação

\begin{tabular}{|c|l|}
\hline Atividades & Produção da Documentação \\
\hline Meta & Produzir e manter os documentos de acordo com os planos estabelecidos. \\
\hline \multirow{5}{*}{ Tarefas } & $\begin{array}{l}\text { 1. Produzir o documento de acordo com os padrões estabelecidos. } \\
\text { 2.Distribuir o documento produzido. } \\
\text { Para facilitar a distribuição os documentos devem estar num } \\
\text { repositório único com acesso controlado aos envolvidos através de } \\
\text { uma ferramenta. Essa ferramenta pode estar numa intranet para } \\
\text { documentos internos e extranet para a visualização do cliente. }\end{array}$ \\
& $\begin{array}{l}\text { 3.Armazenar o documento elegível ao gerenciamento de configuração de } \\
\text { acordo com as atividades desse processo. } \\
\text { 4.Destruir os documentos obsoletos. }\end{array}$ \\
\hline
\end{tabular}

\subsubsection{VERIFICAÇÃO}

Definição: Verificação é o processo que determina se os produtos de uma atividade satisfazem os requisitos ou condições impostas a eles.

A rápida difusão da Internet e novos padrões de tecnologia produziram um significante crescimento da demanda por aplicações Web e por mais e mais requisitos de usabilidade, funcionalidade e confiabilidade. A rápida expansão induziu a necessidade de metodologias e processos para o desenvolvimento de aplicações que fossem adequados a satisfazer os requisitos de qualidade desejados. Um dos processos que impactam significantemente a qualidade de uma aplicação Web é o processo de Verificação.

O objetivo do processo é assegurar que o produto esteja sendo implementado corretamente. O processo de Verificação deve ser integrado aos outros processos que o utilizam o mais rápido possível para melhorar performance.

A Figura 14 apresenta as atividades do processo. 


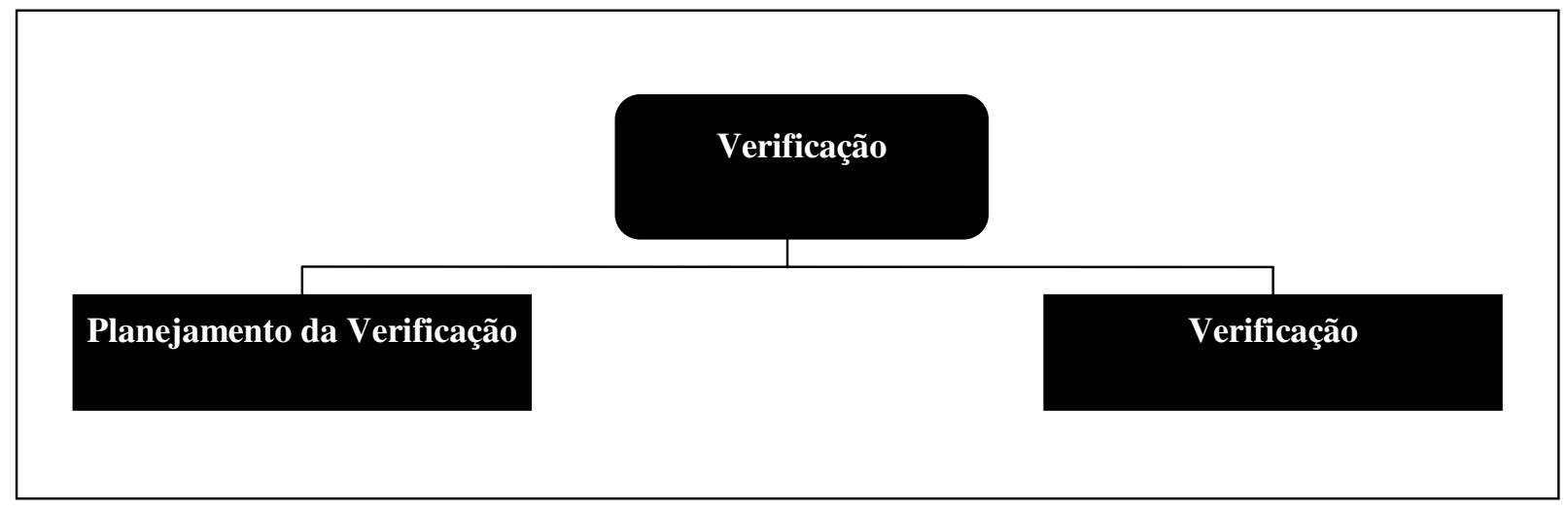

Figura 14: Atividades de Verificação

\section{Planejamento da Verificação}

Definição: a atividade de planejamento é responsável em estabelecer uma estrutura organizacional adequada para a realização do processo de Verificação.

Nesta atividade são definidos os aspectos para implementar e executar diretrizes que tratam cada tarefa de verificação, relacionam recursos, prazos e responsabilidades.

A Figura 15 apresenta as entradas, responsáveis e saídas da atividade.

\section{Entradas}

-Especificação dos

Requisitos

- Planejamento do projeto

- Procedimentos e Normas

de Qualidade

- Saídas de outros processos

Figura 15: Planejamento de Verificação: artefatos e responsáveis

\section{Responsáveis}

- Gerente de Projeto

- Engenheiro de Qualidade

Web

\section{Saídas}

- Plano de Verificação 
Entradas para o Planejamento da Verificação:

- Requisitos do projeto ou escopo do projeto: de acordo com os requisitos e escopo do projeto são definidos os produtos que serão verificados e sob quais aspectos.

- Planejamento do projeto: no planejamento de projeto é definido como os produtos e o projeto serão desenvolvidos. Assim, baseando-se no planejamento, também são definidos critérios de verificação.

- Procedimentos e Normas de Qualidade: de acordo com os procedimentos e normas de qualidade, são definidos critérios para verificação de produtos e processos;

- Saídas de outros processos: processos de outras áreas podem produzir saídas que devem ser consideradas no planejamento de verificação.

Responsáveis:

- Engenheiro de Qualidade Web: auxilia na definição dos critérios de verificação dos produtos e processos.

- Gerente do projeto: identifica os produtos que serão verificados.

Saídas do Planejamento de Verificação:

- Diretrizes de verificação: desenvolvidas para conduzir as atividades e tarefas envolvidas no processo. Descrevem responsabilidades, procedimentos, tarefas e recursos necessários para implementar e executar o processo de Verificação.

O Quadro 9 apresenta as tarefas de Planejamento de Verificação.

Quadro 9: Tarefas de Planejamento de Verificação

\begin{tabular}{|c|l|}
\hline Atividades & Planejamento de Verificação \\
\hline Meta & $\begin{array}{l}\text { Criar um plano de verificação e uma estrutura organizacional adequada para a } \\
\text { realização do processo de Verificação. }\end{array}$ \\
\hline Tarefas & $\begin{array}{l}\text { 1.Identificar Procedimentos e Normas de Qualidade aplicáveis no processo de } \\
\text { Verificação. } \\
\text { A partir dos procedimentos e normas são definidos os critérios de } \\
\text { verificação tanto para o produto quanto para os processos. }\end{array}$ \\
$\begin{array}{l}\text { 2.Identificar as relações com as atividade do processo de Garantia de } \\
\text { Qualidade. } \\
\text { 3.Analisar os requisitos do projeto para estabelecer procedimentos, produtos e }\end{array}$ \\
\hline
\end{tabular}




\begin{tabular}{|c|c|}
\hline Atividades & Planejamento de Verificação \\
\hline & 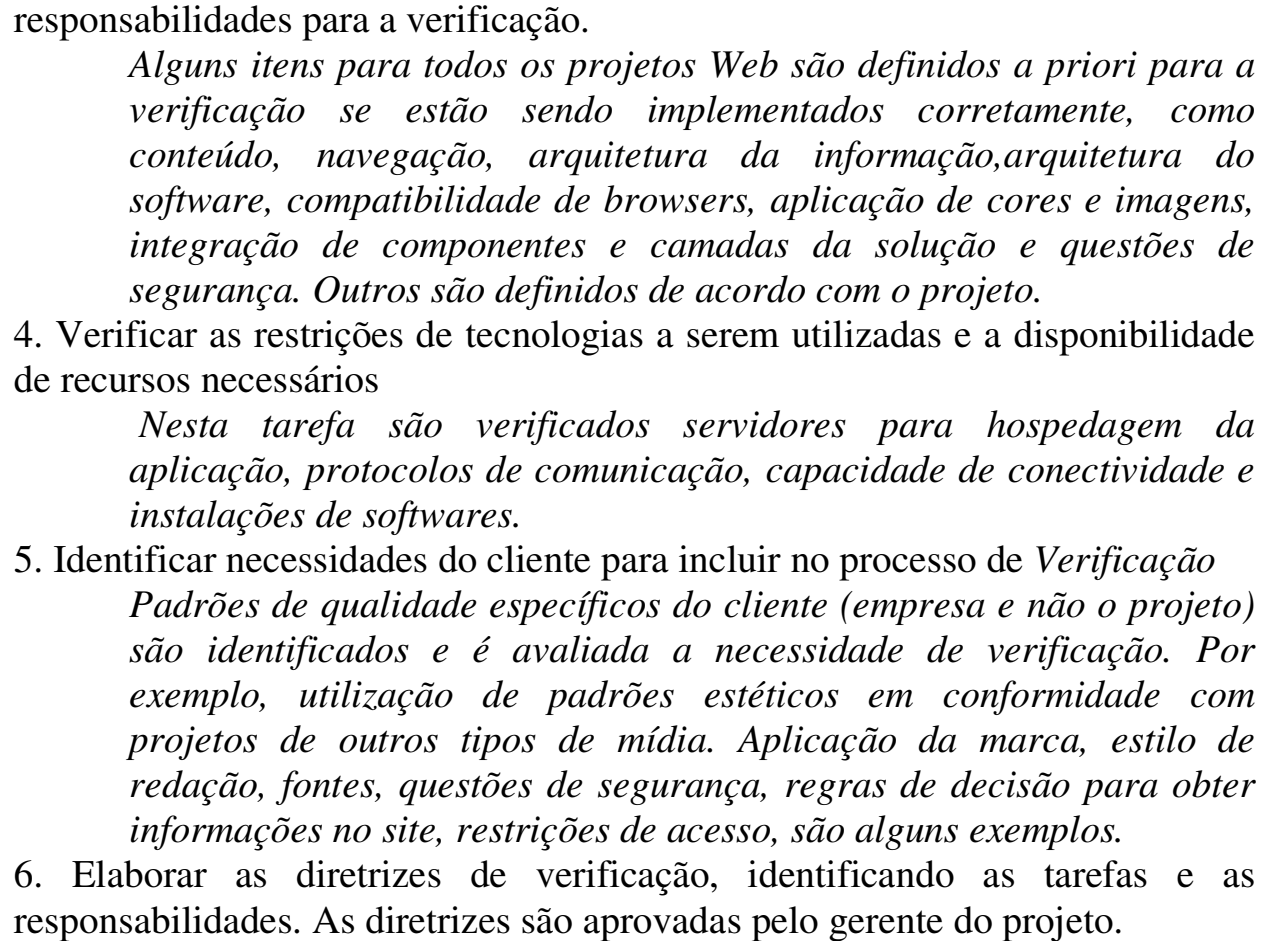 \\
\hline
\end{tabular}

\section{Verificação}

Definição: tem o objetivo de determinar se o produto de uma dada fase do desenvolvimento satisfaz às condições impostas no início dessa fase.

Nesta atividade são realizadas as tarefas propriamente ditas de verificação. Determina se os produtos de uma determinada fase do projeto executam os requisitos estabelecidos previamente e se os processos estão de acordo com os requisitos especificados.

A Figura 16 apresenta as entradas, saídas e responsáveis pela atividade. 


\section{Entradas}

- Plano de Verificação

- Produtos e processos a serem verificados

\section{Responsáveis}

- Gerente de Projeto

- Arquiteto de Software

- Diretor de criação

\section{Saídas}

- Resultados de verificação

Figura 16: Verificação: artefatos e saídas

Entradas para a Verificação:

- Diretrizes de verificação: a verificação é conduzida de acordo com as diretrizes determinadas para o processo.

- Produtos e processos: os produtos, processos e outros itens determinados são verificados.

Responsáveis:

- Gerente do projeto, Arquiteto de Software e Diretor de Criação: verificam se os produtos e processos estão sendo implementados de acordo com os requisitos impostos a eles.

Saídas da Verificação:

- Resultados da verificação: após as verificações são documentados os resultados. Problemas e não conformidades encontrados devem ser tratados no próprio processo. No caso de problemas de alto risco ou que afetam outros processos ou que não possam resolvidos durante a verificação, eles devem ser encaminhados ao processo de Resolução de Problemas.

O Quadro 10 apresenta as tarefas da atividade. 
Quadro 10: Tarefas de Verificação

\begin{tabular}{|c|c|}
\hline Atividades & Verificação \\
\hline Meta & Avaliar se os produtos e processos estão sendo implementados corretamente \\
\hline Tarefas & 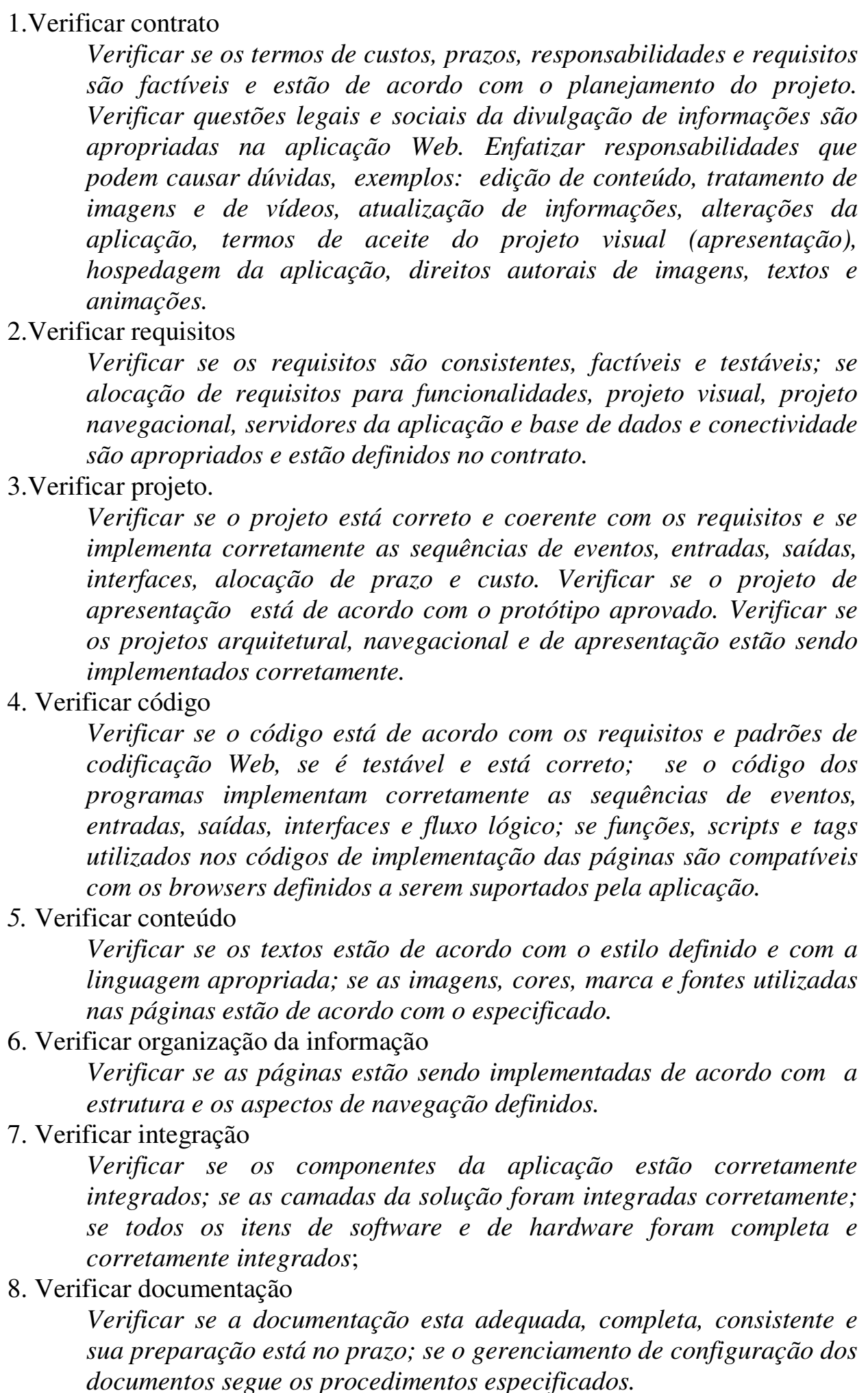 \\
\hline
\end{tabular}




\begin{tabular}{|l|l|}
\hline Atividades & Verificação \\
\hline \multirow{1}{*}{$\begin{array}{l}\text { 9. Verificar processo } \\
\text { Verificar se os processos selecionados para o projeto estão sendo } \\
\text { implementados e executados como planejados; se os padrões, } \\
\text { procedimentos e o ambiente são adequados; se o projeto é gerenciado } \\
\text { e os envolvidos possuem habilidades e treinamento adequados; se os } \\
\text { processos não são onerosos e estão impactando os prazos de entrega. } \\
\text { 10.Documentar resultados e encaminhar problemas e não conformidades ao } \\
\text { processo de Resolução de Problemas. }\end{array}$} \\
\hline
\end{tabular}

\subsubsection{VALIDAÇÃO}

Definição: Validação é o processo que determina se os requisitos específicos para um uso pretendido são atendidos.

A qualidade de uma aplicação Web deve ser mantida e monitorada periodicamente para garantir a qualidade permanente. Qualidade pobre implica que o usuário não mais visitará a aplicação e como conseqüência, a organização pode perder negócios. As questões que afetam a qualidade são, por exemplo, quebra de links, falhas de imagem, mensagens de erros não amigáveis, combinações de cores complexas, links errados, demora de resposta, respostas erradas, etc. Um dos meios de garantir qualidade é através de um processo sistemático de validação. O objetivo da Validação é assegurar que a aplicação que está sendo desenvolvida é a correta de acordo com os requisitos do usuário.

Entre as várias etapas da Validação, a atividade de teste é considerada essencial. O teste é importante para identificação e eliminação de erros, e fornece evidências da confiabilidade da aplicação em complemento a outras atividades.

A Figura 17 apresenta as atividades do processo. 


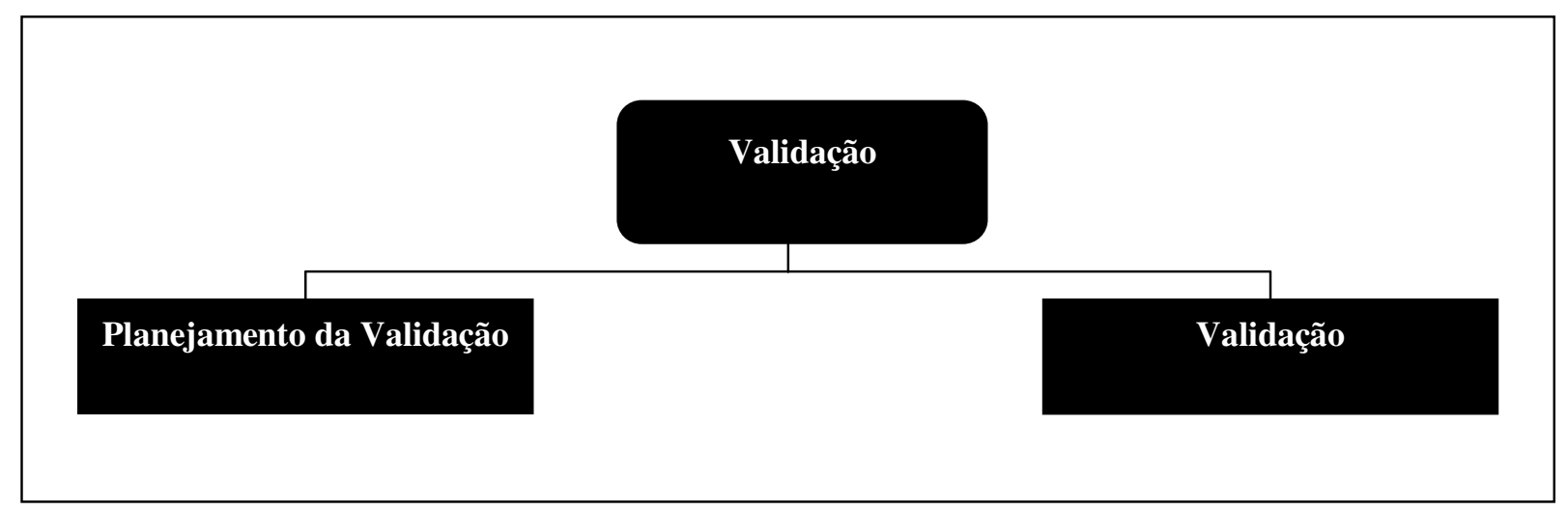

Figura 17: Atividades de Validação

\section{Planejamento da Validação}

Definição: esta atividade estabelece uma estrutura organizacional adequada para a implementação e execução do processo de Validação.

Aborda os aspectos relativos a implementar e documentar um plano para a execução da validação. O plano deve incluir: os itens de validação, tarefas, recursos, responsabilidades e prazo. A Figura 18 apresenta os artefatos de entrada produzidos e os responsáveis pela atividade.

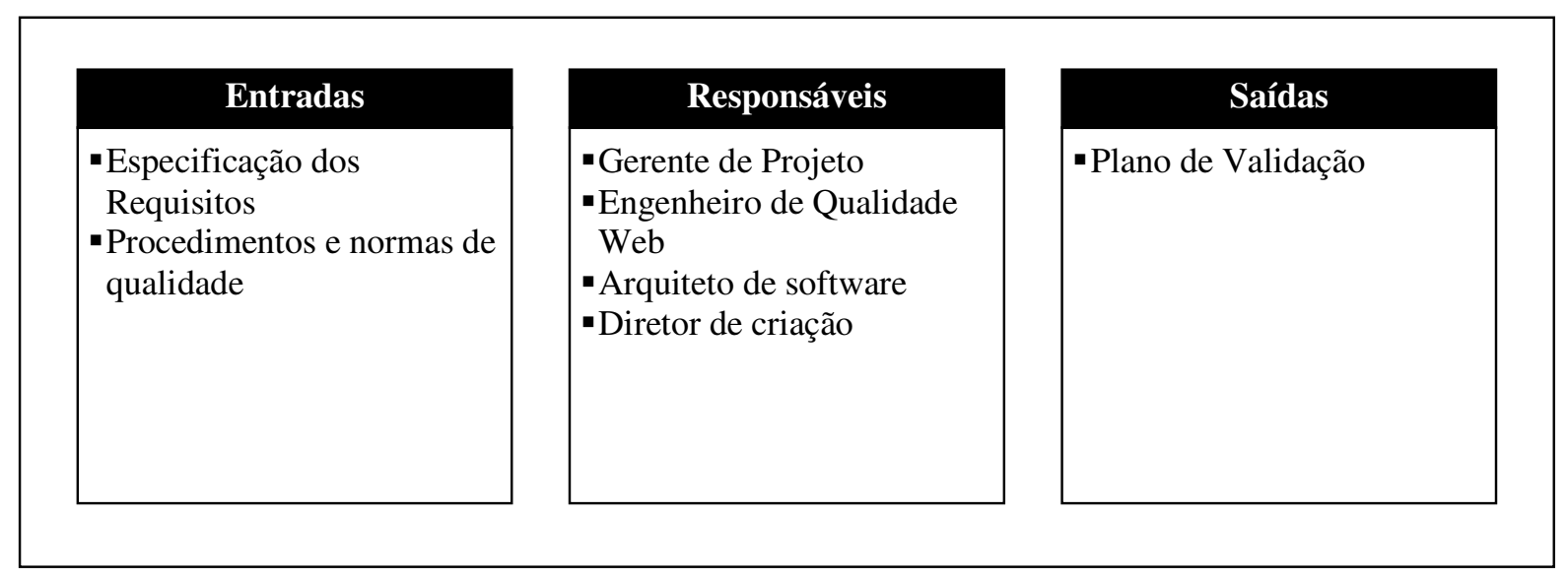

Figura 18: Planejamento de Validação: artefatos e responsáveis.

Entradas para o Planejamento da Validação: 
- Requisitos do projeto ou escopo do projeto: de acordo com os requisitos e escopo do projeto são definidos os itens que serão validados.

- Procedimentos e Normas de Qualidade: de acordo com os procedimentos e normas de qualidade, são definidos critérios para validação dos produtos intermediários e da aplicação.

Responsáveis:

- Engenheiro de Qualidade Web: auxilia na definição dos critérios de validação de acordo com os procedimentos e normas de qualidade.

- Gerente do projeto: identifica os itens que serão validados, define recursos, responsabilidades e prazos.

- Arquiteto de software: identifica os itens de software a serem validados, define métodos, ferramentas, ambiente e outros recursos utilizados.

- Diretor de criação: identifica os itens de apresentação, estrutural e de navegação a serem validados, define métodos, ferramentas, ambiente e outros recursos utilizados.

Saídas do Planejamento da Validação:

- Diretrizes de validação: desenvolvidas para conduzir as atividades e tarefas envolvidas no processo. Descrevem responsabilidades, procedimentos, ambiente, tarefas e recursos necessários para implementar e executar o processo de Validação.

O Quadro 11 apresenta as tarefas da atividade.

Quadro 11: Tarefas de Planejamento de Validação

\begin{tabular}{|c|l|}
\hline Atividades & Planejamento de Validação \\
\hline Meta & $\begin{array}{l}\text { Criar uma estrutura organizacional adequada para a realização do processo de } \\
\text { Validação. }\end{array}$ \\
\hline
\end{tabular}




\begin{tabular}{|c|c|}
\hline Atividades & Planejamento de Validação \\
\hline Tarefas & $\begin{array}{l}\text { 1.Identificar Procedimentos e Normas de Qualidade aplicáveis no processo de } \\
\text { Validação. } \\
\text { A partir dos procedimentos e normas são definidos alguns critérios de } \\
\text { validação. } \\
\text { 2.Identificar as relações com as atividades do processo de Garantia de } \\
\text { Qualidade. } \\
\text { 3.Analisar os requisitos do projeto para estabelecer procedimentos, produtos e } \\
\text { responsabilidades para a validação. } \\
\text { Definir os níveis de teste; elaborar estratégias para validação de } \\
\text { funcionalidades, da apresentação, conteúdo, navegação, performance } \\
\text { e infra-estrutura (servidores e conectividade); definir métodos de teste } \\
\text { para cada item; estabecer quando e quem executaria os testes; e } \\
\quad \text { definir quanto de esforço será utilizado. Utilizar testes automatizados. } \\
\text { 4. Preparar o ambiente de teste. } \\
\text { Preparar o ambiente de teste de acordo com as especificações } \\
\text { necessárias para reproduzir o ambiente real. } \\
\text { 5. Determinar como o cliente realizará os testes de aceite da aplicação. } \\
\text { 6. Elaborar as diretrizes de validação, identificando as tarefas, recursos e as } \\
\text { responsabilidades. As diretrizes são aprovadas pelo gerente do projeto. }\end{array}$ \\
\hline
\end{tabular}

\section{Validação}

Definição: consiste na validação dos produtos através do plano definido para o processo.

Esta atividade é relativa à validação propriamente dita. As aplicações Web variam muito em funcionalidades, apresentação e questões dos usuários. As aplicações são dinâmicas em sua natureza e requerem uma robusta metodologia de teste.

A produção de produtos intermediários no desenvolvimento de aplicações Web é grande e diversificado, o que aumenta o número de elementos a serem validados, assim como aumenta o número de possibilidades de erro.

A Figura 19 apresenta os artefatos de entrada e saída, e os responsáveis pela atividade. 


\section{Entradas}

- Plano de Validação

- Produtos e processos a

serem validados

\section{Responsáveis}

- Gerente de Projeto

- Testador

- Cliente

\section{Saídas}

- Resultados da validação

Figura 19: Validação: artefatos e responsáveis

Entradas para a Validação:

- Plano de validação: a validação é conduzida de acordo com as diretrizes determinadas para o processo.

- Produtos: os produtos e seus requisitos que serão validados.

Responsáveis:

- Gerente do projeto: acompanha a realização dos testes e toma as providências nos casos de não conformidades e erros.

- Testador: realiza os testes da aplicação.

- Cliente: a cada entrega de novas funcionalidades ou novas versões, o cliente é responsável em testá-las e aceitá-las ou não, no caso de erros ou falhas.

Saídas da Validação:

- Resultados da validação: após as validações, os resultados são documentados. Problemas e não conformidades encontrados devem ser encaminhados inicialmente ao responsável pelo produto testado. Porém, se os erros não forem consertados, ou problemas forem de alto risco, ou afetarem outros produtos devem ser encaminhados ao processo de Resolução de Problemas.

O Quadro 12 apresenta as tarefas da atividade. 
Quadro 12:Tarefas de Validação

\begin{tabular}{|c|c|}
\hline Atividades & Validação \\
\hline Meta & Determinar se o produto satisfaz o uso pretendido. \\
\hline Tarefas & 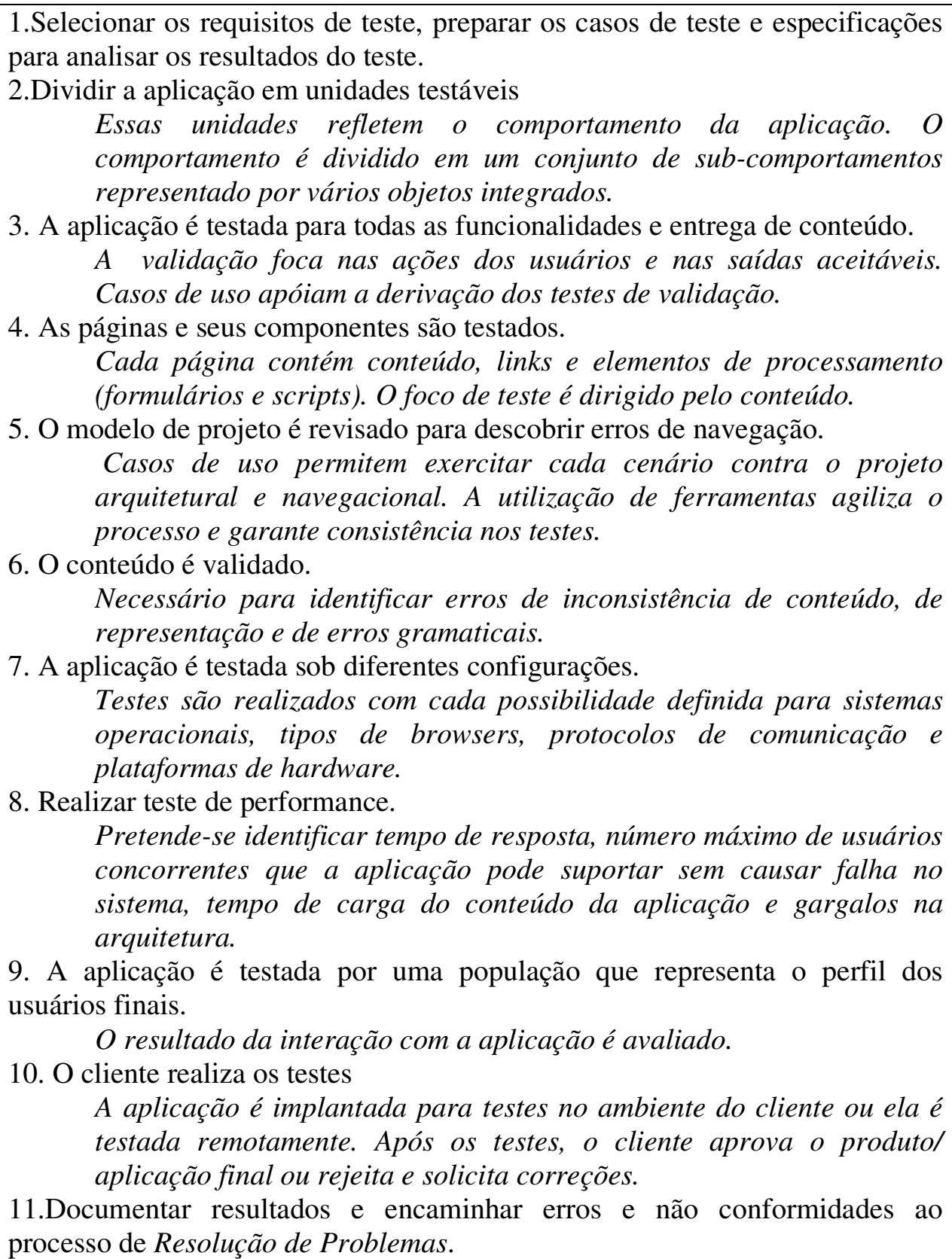 \\
\hline
\end{tabular}




\subsubsection{GARANTIA DA USABILIDADE}

Definição: Usabilidade é o processo para garantir os interesses e necessidades do usuário e da organização, melhorando a produtividade e a qualidade de uso da aplicação Web e reduzindo as chances de rejeição do usuário com a aplicação.

Uma característica de qualidade de grande importância para o sucesso de uma aplicação Web é a usabilidade. O valor da usabilidade é amplamente conhecido, diversos pesquisadores têm descrito seu benefício para o usuário, para o desenvolvedor e para a organização. A usabilidade de uma aplicação não apenas lida com a interface do usuário, está também relacionada com toda a estrutura do software e com os conceitos na qual a aplicação é baseada.

Dessa forma, os desenvolvedores devem alinhar os objetivos de usabilidade com o desenvolvimento Web. Por isso, aqui é apresentado um processo para apoiar a integração com o desenvolvimento e garantir a alta qualidade da experiência do usuário com a aplicação.

A Figura 20 apresenta as atividades do processo.

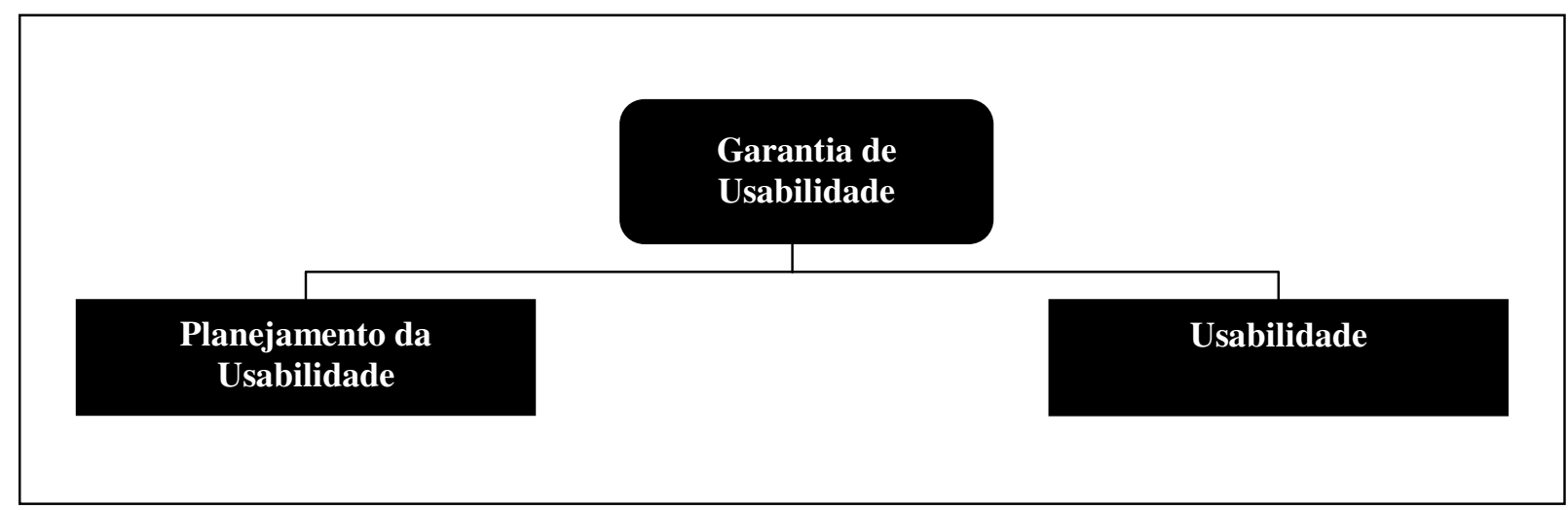

Figura 20: Atividades de Garantia de Usabilidade 


\section{Planejamento da Usabilidade}

Definição: esta atividade planeja as tarefas do processo de Usabilidade. Especifica como as atividades são integradas com os outros processos do ciclo de vida da aplicação.

Os procedimentos definidos no plano de usabilidade devem ser realizados ao longo do ciclo de desenvolvimento do projeto.

A Figura 21 apresenta as entradas, responsáveis e saídas da atividade.

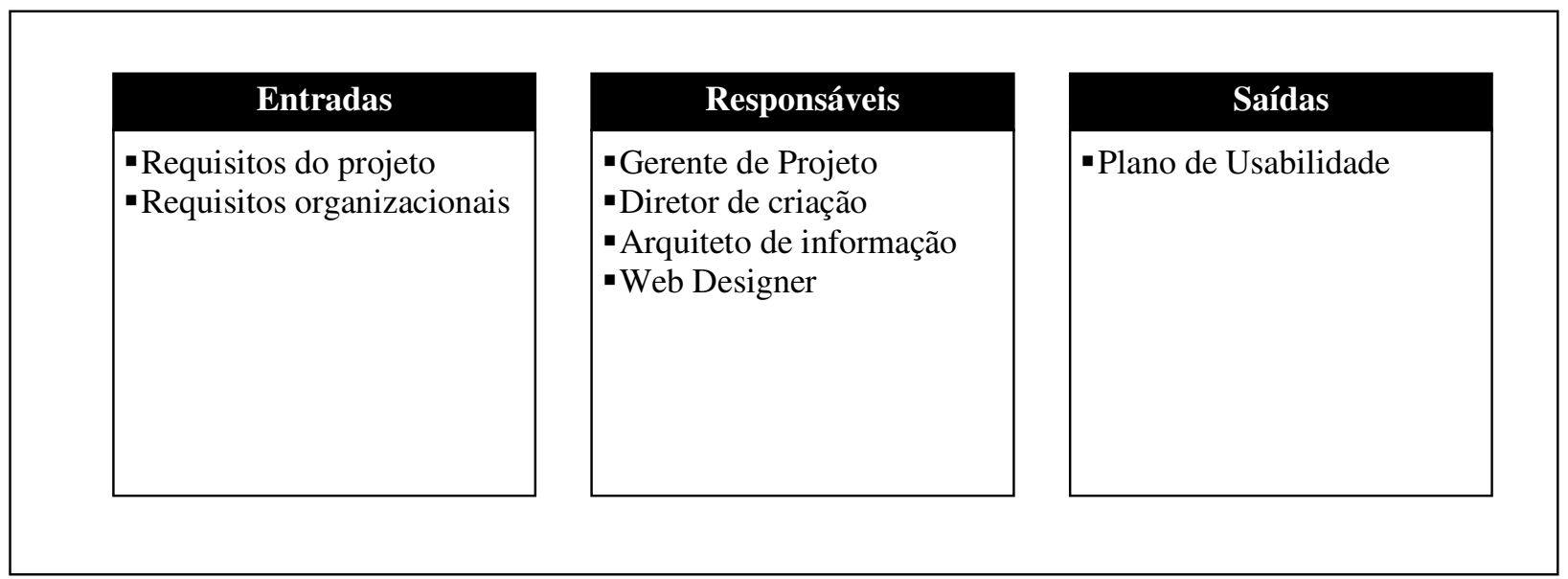

Figura 21:Planejamento de Usabilidade: artefatos e responsáveis

Entradas para o Planejamento da Usabilidade:

- Requisitos do projeto: de acordo com os requisitos são identificadas as funcionalidades, os atributos de qualidade, o perfil do usuário e o ambiente, nos quais são baseados para a definição das tarefas para o processo.

- Requisitos organizacionais: determina os critérios de sucesso de usabilidade para a aplicação em termos de tarefas dos usuários. Determina restrições e algumas diretrizes para o projeto.

Responsáveis:

- Gerente do projeto: planeja as atividades de Usabilidade e define a integração das atividades do processo de Usabilidade dentro de todo o desenvolvimento.

- Diretor de Criação, arquiteto de informação e Web designer: planejam as atividades de Usabilidade, definem técnicas e métodos de desenvolvimento 
centralizado no usuário, analisas o perfil dos usuários e identificam seus atributos.

Saídas do Planejamento de Usabilidade:

- Plano de Usabilidade: desenvolvido para conduzir as atividades e tarefas envolvidas no processo. Descrevem responsabilidades, procedimentos, ambiente, tarefas e recursos necessários para implementar e executar o processo de Usabilidade.

O Quadro 13 apresenta as tarefas da atividade.

Quadro 13: Tarefas de Planejamento de Usabilidade

\begin{tabular}{|c|c|}
\hline Atividades & Planejamento da Usabilidade \\
\hline Meta & $\begin{array}{l}\text { Criar um plano e uma estrutura organizacional adequada para a realização do } \\
\text { processo de Usabilidade. }\end{array}$ \\
\hline Tarefas & $\begin{array}{l}\text { 1. Selecionar os métodos e técnicas de desenvolvimento centralizados nos } \\
\text { usuários. } \\
\text { 2. Planejar as atividades de Usabilidade. } \\
\quad \text { São analisados os requisitos do projeto e organizacionais, para } \\
\text { identificar os atributos e objetivos de Usabilidade e definir atividades } \\
\quad \text { para garantia desses atributos. } \\
\text { 3. Estabelecer a integração das atividades de Usabilidade nos processos de } \\
\text { desenvolvimento da aplicação. } \\
\quad \text { O desenvolvimento deve ser direcionado de acordo com as } \\
\text { necessidades de Usabilidade. } \\
\text { 4. Estabelecer e garantir o gerenciamento das atividades de Usabilidade e } \\
\text { definir responsabilidades. } \\
\text { 5. Gerar um plano de Usabilidade, que deve ser aprovado pelo gerente e } \\
\text { distribuído a toda a equipe. }\end{array}$ \\
\hline
\end{tabular}

\section{Usabilidade}

Definição: a atividade garante a execução do plano definido para o processo e executa tarefas para alcançar a qualidade esperada da experiência dos usuários com a aplicação. 
Para o sucesso do projeto, é necessário que os atributos de Usabilidade estejam definidos e garantidos em todas as atividades do ciclo de desenvolvimento.

A Figura 22 apresenta as entradas, responsáveis e saídas da atividade.

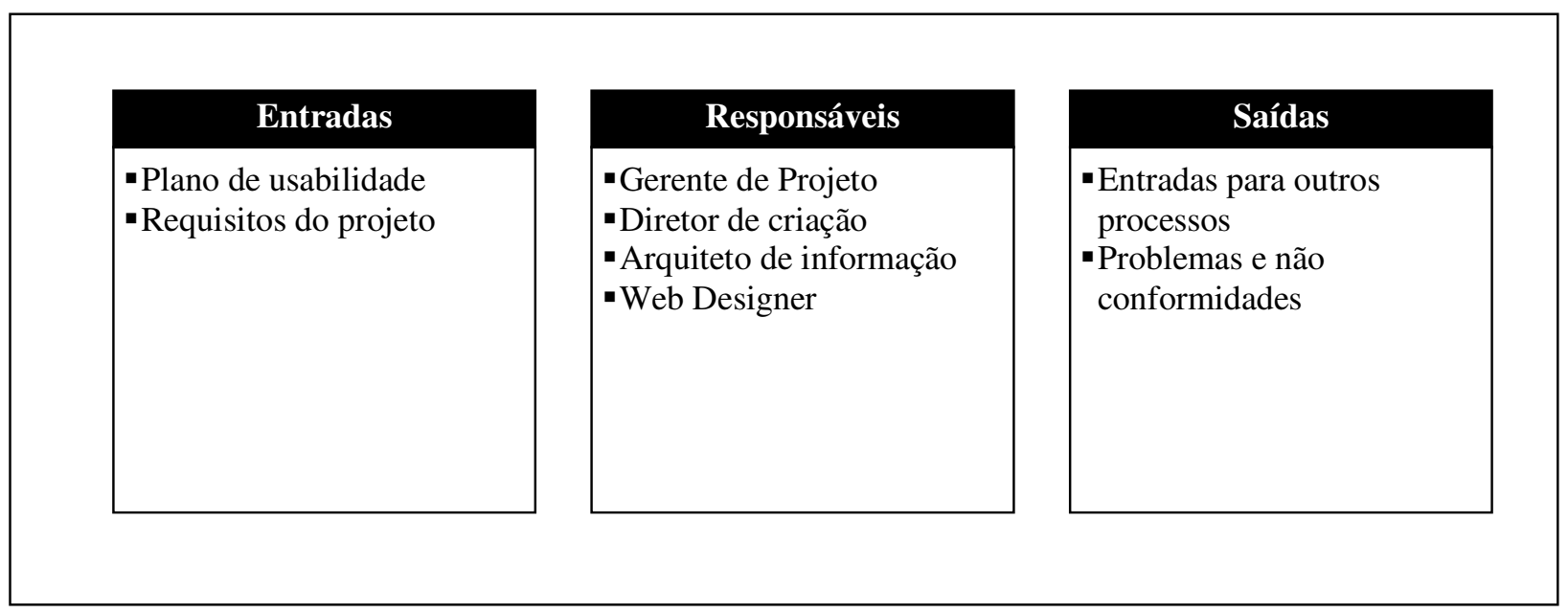

Figura 22: Usabilidade: artefatos e responsáveis

Entradas para Usabilidade:

- Plano de usabilidade: de acordo com as atividades e responsabilidades definidas no plano de Usabilidade a atividade é executada.

- Requisitos do projeto: de acordo com os requisitos são identifadas as funcionalidades, os atributos de qualidade, o perfil do usuário, o ambiente de uso e para que o produto será utilizado. E dessa forma os projetos arquitetural, navegacional e de conteúdo são criados.

- Requisitos organizacionais: determina os critérios de sucesso de usabilidade para a aplicação em termos de tarefas dos usuários. Determina restrições e algumas diretrizes para o projeto.

Responsáveis:

- Gerente do projeto: garante e gerencia a execução das tarefas de Usabilidade definidas para o projeto.

- Diretor de Criação: coordena e desenvolve os projetos arquitetural, navegacional e de conteúdo, identifica perfil do usuário e estabelece as diretrizes para a criação da identificação visual e cognitiva da aplicação.

- Arquiteto de Informação: estabelece a organização da informação dentro de cada página da aplicação e desenvolve os projetos arquitetural e navegacional. 
- Web designer: cria as páginas de acordo com as definiçõoes de componentes estabelecidos..

Saídas de Usabilidade:

- Entradas para outros processos: a atividade de garantia de Usabilidade, gera produtos que são utilizados por outros processos. Por exemplo, requisitos para o projeto da arquitetura do software.

- Problemas e não conformidades: se durante a execução das tarefas de Usabilidade, forem encontrados problemas ou não-conformidades, esses devem ser reportados ao processo de Resolução de Problemas.

O Quadro 14 apresenta as tarefas de Garantia de Usabilidade.

Quadro 14: Tarefas de Usabilidade

\begin{tabular}{|c|c|}
\hline Atividades & Usabilidade \\
\hline Meta & Garantir a alta qualidade da usabilidade da aplicação Web. \\
\hline Tarefas & $\begin{array}{l}\text { 1. Entender e especificar o contexto do uso da aplicação e estabelecer seu } \\
\text { objetivo. } \\
\text { 2. Analisar as especificações de requisitos da aplicação e organizacionais. } \\
\text { 3. Estabelecer o perfil dos usuários } \\
\text { Quando a aplicação Web é para residir numa intranet ou extranet, a } \\
\text { identificação do perfil dos usuários é mais fácil, pois os usuários são } \\
\text { definidos. No caso de aplicações que estão na rede mundial, o perfil é } \\
\text { mais complexo e deve ser definido baseado em questões que podem } \\
\text { mais caracterizá-los de acordo com os objetivos da aplicação. } \\
\text { Exemplos, aplicações de instituições bancárias, perfil dos correntistas; } \\
\text { portais para crianças, idade; aplicações para revistas femininas, sexo } \\
\text { e idade. } \\
\text { 4. Desenhar layouts, criar apresentações estáticas de páginas e desenhar } \\
\text { conteúdos. Apresentá-los para o cliente e aprová-los. } \\
\text { 5. Criar um protótipo, apresentar para o cliente e validá-lo. } \\
\text { O protótipo é criado numa arquitetura simplificada. Somente um } \\
\text { conjunto de páginas são implementadas manualmente contendo } \\
\text { amostras do conteúdo da aplicação e da estética, simula o desejo da } \\
\text { aparência e comportamento. } \\
\text { 6. Desenvolver os projetos arquitetural, navegacional e de conteúdo e avaliá- } \\
\text { los se estão de acordo com os requisitos. } \\
\text { 7. Aplicar testes para avaliar performance, consistência do projeto, conteúdo } \\
\text { da informação e estrutural, de acordo com as atividades de Validação. } \\
\text { 8. Encaminhar problemas ou não conformidades ao processo de Resolução de } \\
\text { Problemas. }\end{array}$ \\
\hline
\end{tabular}




\subsubsection{GERENCIAMENTO DE CONFIGURAÇÃO}

Definição: o processo de Gerenciamento de Configuração visa identificar e controlar as modificações de itens do projeto e recuperá-los do respositório, garantir que a mudança está sendo realizada da maneira apropriada e reportar as mudanças para os interessados.

Gerenciamento de Configuração é um processo fundamental para o desenvolvimento de aplicações Web. Mudanças impróprias e sem controle causam problemas não só localmente, mas propaga o erro por diversas aplicações e afeta o trabalho de toda a equipe, assim como, de milhares de usuários.

Como dito, as aplicações Web são baseadas em conteúdo multimídia. O desafio é organizá-lo de maneira racional num conjunto de objetos de configuração e estabelecer mecanismos apropriados de controle para esses objetos.

As ferramentas de apoio ao gerenciamento de configuração têm que lidar com o controle de versões de imagens, som e áudio, sabendo-se que é muito complexo mostrar diferenças entre esses elementos.

É muito importante também o controle de versão da infra-estrutura definida na aplicação, pois ela é solicitada por diversas aplicações associadas com diferentes sistemas operacionais, browsers e plataformas. Então, para quaisquer problemas na qual se deseje voltar alguma versão da aplicação, o controle de configuração da infra-estrutura deve estar assegurado.

A Figura 23 apresenta as atividades do processo. 


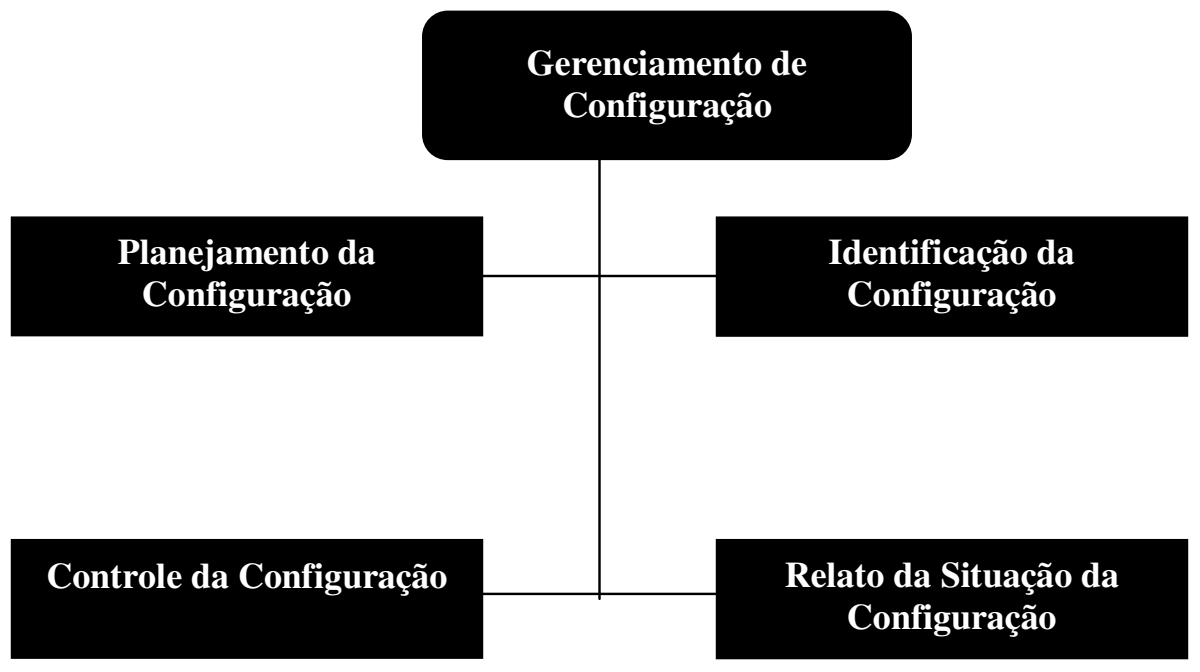

Figura 23: Atividades de Gerenciamento de Configuração

\section{Planejamento da Configuração}

Definição: a atividade de planejamento é responsável em estabelecer uma estrutura organizacional adequada para a realização do processo de Gerenciamento de Configuração.

A Figura 24 apresenta as entradas, responsáveis e saídas. 


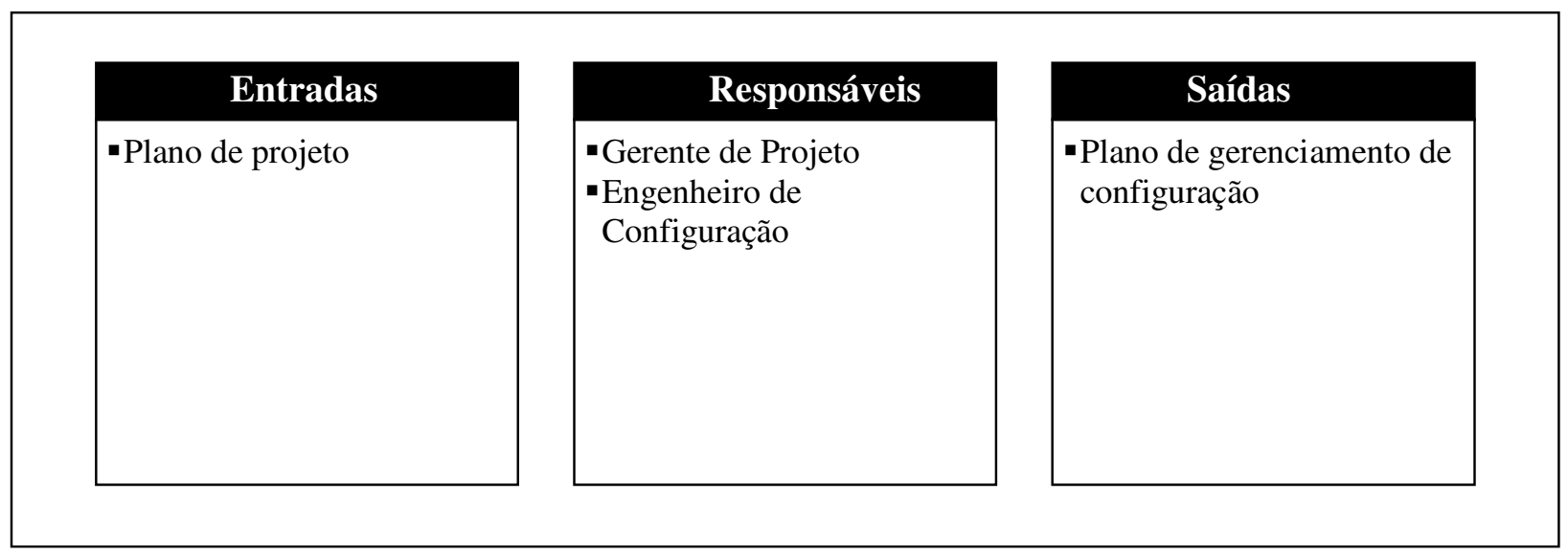

Figura 24: Planejamento de Configuração: artefatos e responsáveis

Entradas para o Planejamento da Configuração:

- Plano de projeto: descreve todo o planejamento do projeto, as tarefas envolvidas, os produtos produzidos, papéis e prazos. De acordo com os produtos produzidos e os prazos são estabelecidos os procedimentos do gerenciamento de configuração.

Responsáveis:

- Gerente do projeto: descreve o escopo do projeto, identifica as responsabilidades e autoridades para realizar as atividades de gerenciamento de configuração.

- Engenheiro de Configuração: identifica ferramentas, recursos e as atividades a serem executadas no processo.

Saídas do Planejamento de Configuração:

- Plano de Gerenciamento de Configuração: descreve os procedimentos, prazos, responsabilidades e atividades relacionadas a implantação e administração do processo.

O Quadro 15 apresenta as tarefas da atividade. 
Quadro 15: Tarefas de Planejamento de Configuração

\begin{tabular}{|c|l|}
\hline Atividades & Planejamento do Gerenciamento de Configuração \\
\hline Meta & $\begin{array}{c}\text { Gerar um plano de gerenciamento de configuração. } \\
\text { 1. Descrever o escopo da aplicação. } \\
\text { 2.Estabelecer as atividades e procedimentos a serem executados no processo } \\
\text { de Gerenciamento de Configuração. } \\
\text { 3.. Identificar as responsabilidades e autoridades para realizar as atividades. } \\
\text { 4. Identificar a coordenação necessária das atividades deste processo com as } \\
\text { outras atividades do projeto. } \\
\text { 5. Identificar ferramentas e recursos físicos para a execução das atividades. } \\
\text { A dificuldade está em estabelecer ferramentas e mecanismos } \\
\text { apropriados para o controle de itens que envolvem conteúdo } \\
\text { multimídia. }\end{array}$ \\
$\begin{array}{l}\text { 7. Gerar um plano de Gerenciamento de Configuração, que deve ser aprovado } \\
\text { pelo gerente do projeto. }\end{array}$ \\
\hline
\end{tabular}

\section{Identificação da Configuração}

Definição: é estabelecido um esquema para a identificação dos itens e de suas versões a serem controlados.

A Figura 25 apresenta as entradas, responsáveis e saídas.

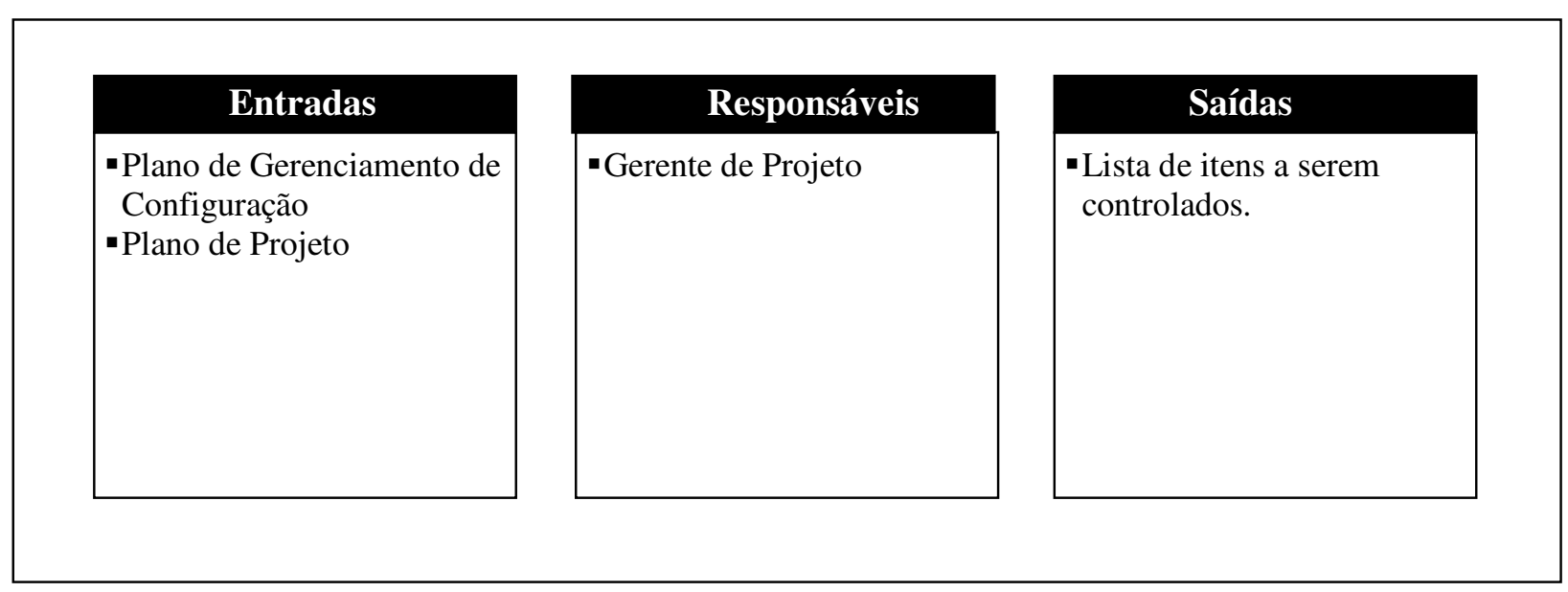

Figura 25: Identificação de Configuração: artefatos e responsáveis. 
Entradas para Identificação da Configuração:

- Plano de Gerenciamento de Configuração: de acordo com o Plano de Gerenciamento de Configuração, são executadas as atividades.

- Plano de projeto: de acordo com os produtos produzidos são estabelecidos os itens a serem gerenciados no processo.

Responsáveis:

- Gerente do projeto: identifica os itens a serem gerenciados no processo.

Saídas:

- Lista de Itens: os itens de configuração são listados e divulgados para que assim que ultrapassar uma baseline, os itens sejam colocados sob gerenciamento de configuração.

O Quadro 16 apresenta as tarefas da atividade

Quadro 16: Tarefas de Identificação de Configuração

\begin{tabular}{|c|l|}
\hline Atividades & Identificação da Configuração \\
\hline Meta & Definir os itens de software que serão controlados durante o projeto. \\
\hline Tarefas & $\begin{array}{l}\text { 1. Definir os itens de configuração que serão colocados sob controle de } \\
\text { configuração. } \\
\text { Os itens podem ser códigos fontes, documentos de projeto, tipos de } \\
\text { browsers suportados pela aplicação, versões de componentes, } \\
\text { conteúdos, versões de mídias, etc. }\end{array}$ \\
& $\begin{array}{l}\text { 2. Estabelecer um esquema para identificar unicamente cada item sob controle } \\
\text { de configuração, assim como o relacionamento entre os itens. } \\
\text { 3. Estabelecer as baselines (linhas de referência). } \\
\text { 4. Descrever como cada item será arquivado e recuperado. }\end{array}$ \\
\hline
\end{tabular}

\section{Controle da Configuração}

Definição: abrange o controle das requisições de alterações dos itens sob controle de configuração e avaliações dessas alterações.

A Figura 26 apresenta as entradas, responsáveis e saídas da atividade. 


\section{Entradas}

- Plano de Gerenciamento de Configuração

- Pedido de alteração de um item

\section{Responsáveis}

- Gerente de Projeto

- Gerente de Configuração

\section{Saídas}

- Decisão sobre o pedido de alteração

- Item a ser modificado

- Problemas e não

conformidades encontradas

Figura 26: Controle de Configuração: artefatos e saídas

Entradas para Controle da Configuração:

- Plano de Gerenciamento de Configuração: de acordo com esse plano, são executadas as atividades.

- Pedido de alteração de um item: pedido de alteração de um item que já passou pela linha de referência.

Responsáveis:

- Gerente do projeto: aprova ou rejeita o pedido de alteração e avalia o item modificado.

- Gerente de configuração: gerencia a permissão para retirar os itens de configuração necessários do repositório e o disponibiliza.

Saídas:

- Decisão sobre o pedido de alteração: o gerente de projeto analisa o pedido e toma a decisão sobre esse pedido.

- Item que será alterado: itens são retirados após aprovação do Gerente.

- Problemas e não-conformidades: problemas encontrados durante a decisão do pedido ou alterações erradas, por exemplo, alterações de alto risco, devem ser encaminhados ao processo de Resolução de Problemas. 
O Quadro 17 apresenta as tarefas do processo.

Quadro 17: Tarefas de Controle de Configuração

\begin{tabular}{|c|c|}
\hline Atividades & Controle da Configuração \\
\hline Meta & $\begin{array}{l}\text { Avaliar os pedidos de mudança, de acordo com os procedimentos definidos, e } \\
\text { disponibilizar o item para modificação. }\end{array}$ \\
\hline Tarefas & $\begin{array}{l}\text { 1. Avaliar o pedido de alteração e relatar os resultados da avaliação. } \\
\text { A alteração deve ser avaliada em relação as necessidades reais de } \\
\text { mudanças no item, ao risco de alteraçães e impacto no projeto. O } \\
\text { pedido só é necessário no caso dos itens que já passaram por uma } \\
\text { baseline, antes os documentos são alterados livremente de acordo com } \\
\text { a autoridade sobre o documento. } \\
\text { 2. Tomar a decisão sobre o pedido de alteração. } \\
\text { 3. Se o pedido for aceito } \\
\text { - Definir prioridade de execução do pedido; } \\
\text { - Disponibilizar o item na área de trabalho (check out); } \\
\text { - Realizar as alterações de acordo com a aprovação do gerente do } \\
\text { projeto; } \\
\text {-Avaliar os aspectos modificados de cada item de acordo com o } \\
\text { processo de Verificação; } \\
\text { 3. Verificar se o projeto e a documentação estão atualizados. } \\
\text { 4. Encaminhar problemas e não conformidades ao processo de Resolução de } \\
\text { Problemas. }\end{array}$ \\
\hline
\end{tabular}

\section{Relato da Situação da Configuração}

Definição: o objetivo é relatar a todas as pessoas envolvidas no desenvolvimento e manutenção da aplicação Web informações sobre as alterações na configuração.

A Figura 27 apresenta as entradas, responsáveis e saídas da atividade. 
Entradas

-Plano de Gerenciamento de

Configuração

- Item alterado

\section{Responsáveis}

- Gerente de Configuração
Saídas

- Item alterado

- Relatório da situação da

configuração do projeto

Figura 27: Relato da Situação da Configuração: artefatos e responsáveis

Entradas para Relato da Situação da Configuração:

- Plano de Gerenciamento de Configuração: de acordo com esse plano, são executadas as atividades.

- Item alterado: o item alterado, que já passou por uma baseline, é armazenado no repositório.

Responsáveis:

- Gerente de Configuração: armazena o item alterado e faz os relatórios sobre a configuração do projeto.

Saídas:

- Item alterado: a versão atualizada do item é enviada aos envolvidos com o item.

- Relatórios sobre a situação da configuração do projeto: deve incluir o número de mudanças de um projeto, o responsável pelas alterações, o que e quando ocorreu, o que será afetado e as últimas versões dos itens.

O Quadro 18 apresenta as tarefas da atividade. 
Quadro 18: Tarefas de Relato da Situação da Configuração

\begin{tabular}{|c|c|}
\hline Atividades & Relato da Situação da Configuração \\
\hline Meta & $\begin{array}{l}\text { Armazenar o item alterado e gerar um relatório com as alterações dos itens de } \\
\text { configuração. }\end{array}$ \\
\hline Tarefas & $\begin{array}{l}\text { 1. Após a aprovação da verificação da alteração do item, armazenar os itens de } \\
\text { configuração alterados no repositório (check in). } \\
\text { 2. Gerar um relatório sobre as alterações ocorridas. } \\
\text { Descrever o responsável pelas alterações, o que e quando ocorreu, o } \\
\text { que será afetado e as últimas versões dos itens. } \\
\text { 3. Divulgar o relatório aos interessados e aos responsáveis pela atividade que } \\
\text { executa tarefas sobre os itens que foram modificados. }\end{array}$ \\
\hline
\end{tabular}

\subsection{RESOLUÇÃO de PROBLEMAS}

Definição: este processo tem o objetivo de analisar e resolver os problemas, qualquer que seja sua origem e natureza, que são encontrados durante o ciclo de vida da aplicação.

A produção de produtos intermediários no desenvolvimento de aplicações Web é grande e diversificado, o que aumenta o número de elementos a serem verificados e validados, assim como aumenta o número de possibilidades de erro.

Como as aplicações Web interagem com diferentes sistemas operacionais, browsers, hardware, plataformas, e protocolos de comunicação, a busca pela origem e motivos dos erros representa um desafio.

Nas aplicações Web, é mais difícil de isolar o erro devido ao sistema ser multicamadas e também de se resolver, pois, geralmente, a propagação de um erro através das camadas e dos elementos de processamento é grande devido ao inter-relacionamento entre eles.

Como as aplicações são acessadas por milhares de usuários, se o erro não for identificado antes da entrega da aplicação final, o problema pode ser grave. Por exemplo, o 
cálculo errado de um produto vendido numa aplicação de comércio eletrônico, causa grandes prejuízos financeiros. Erros que atingem o usuário final causam desgastes da imagem da organização, além de questões legais e sociais.

A Figura 28 apresenta as atividades do processo.

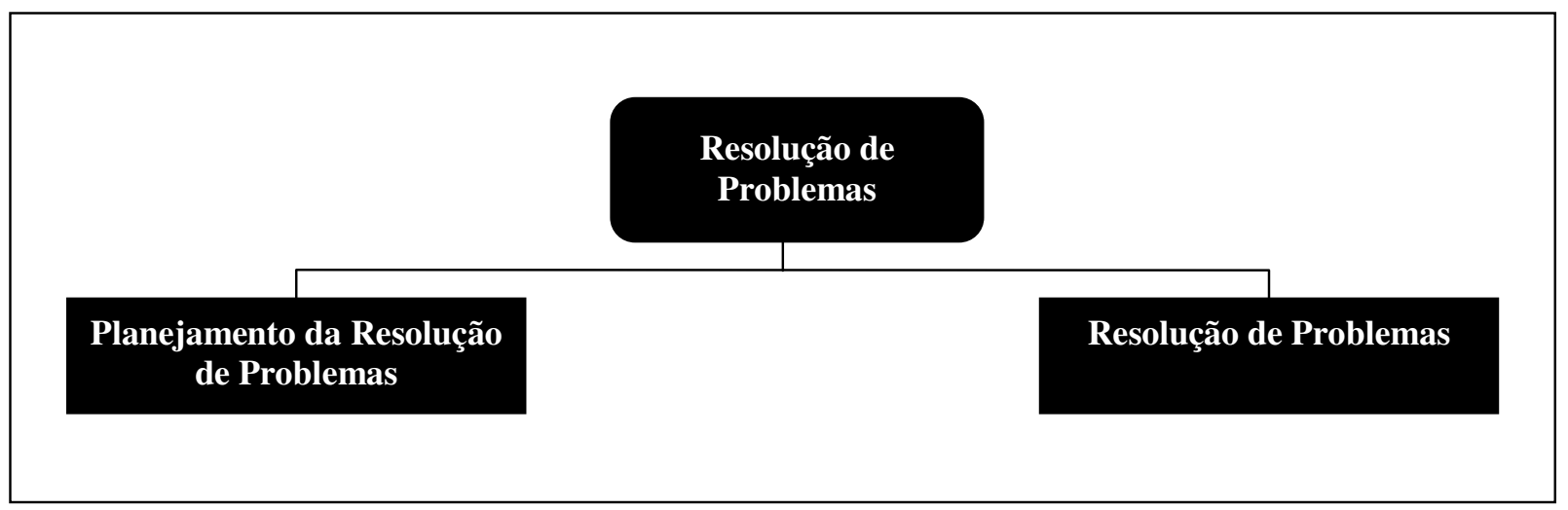

Figura 28: Atividades de Resolução de Problema

\section{Planejamento de Resolução de Problemas}

Definição: a atividade de planejamento é responsável em estabelecer uma estrutura organizacional adequada para a realização do processo de Resolução de Problemas.

A Figura 29 apresenta as entradas, responsáveis e saídas da atividade.

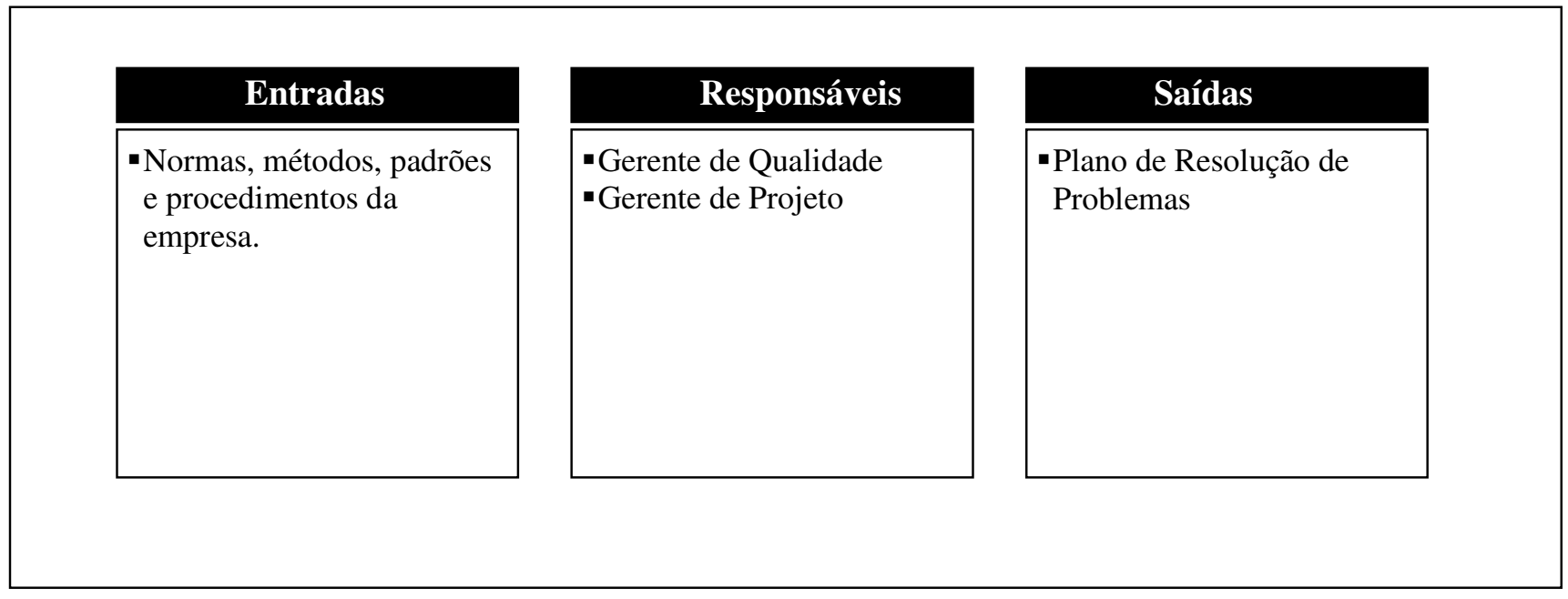

Figura 29: Planejamento da Resolução de Problemas: artefatos e responsáveis 
Entradas para Planejamento de Resolução de Problemas:

- Normas, métodos, padrões e procedimentos da empresa: as tarefas definidas para o processo de Resolução de Problemas, são criadas respeitando as normas e procedimentos da empresa frente a um problema.

Responsáveis:

- Gerente de Qualidade Web: auxilia na definição de tarefas visando tratar tanto problemas de produto quanto de processos.

- Gerente de Projeto: determina prazos e meios para garantir que os problemas sejam analisados e resolvidos.

Saídas:

- Plano de Resolução de Problemas: estabelece procedimentos, responsabilidades e prazos para a análise e solução dos problemas.

O Quadro 19 apresenta as tarefas da atividade.

Quadro 19: Tarefas de Planejamento de Resolução de Problemas

\begin{tabular}{|c|l|}
\hline Atividades & Planejamento de Resolução de Problemas \\
\hline Meta & Gerar um plano para a execução do processo de Resolução de Problemas. \\
\hline Tarefas & $\begin{array}{l}\text { 1..Estabelecer as atividades e procedimentos a serem executados no processo } \\
\text { de Resolução de Problemas. } \\
\text { 2. Definir um esquema para categorizar e priorizar os problemas. } \\
\text { com as atividades de outros processos. } \\
\text { 4. Determinar para quais tipos de problema e qual o momento de envolver o } \\
\text { cliente. } \\
\text { 5. Garantir que após a detecção de um problema, ele seja rapidamente } \\
\text { notificado, as causas detectadas e se possível eliminadas. } \\
\text { 6. Gerar um plano de Resolução de Problemas aprovado pelo gerente. }\end{array}$ \\
\hline
\end{tabular}




\section{Resolução de Problemas}

Definição: atividade que garante a investigação, análise e identificação, e se possível, a eliminação de um problema.

A Figura 30 apresenta as entradas, responsáveis e saídas da atividade.

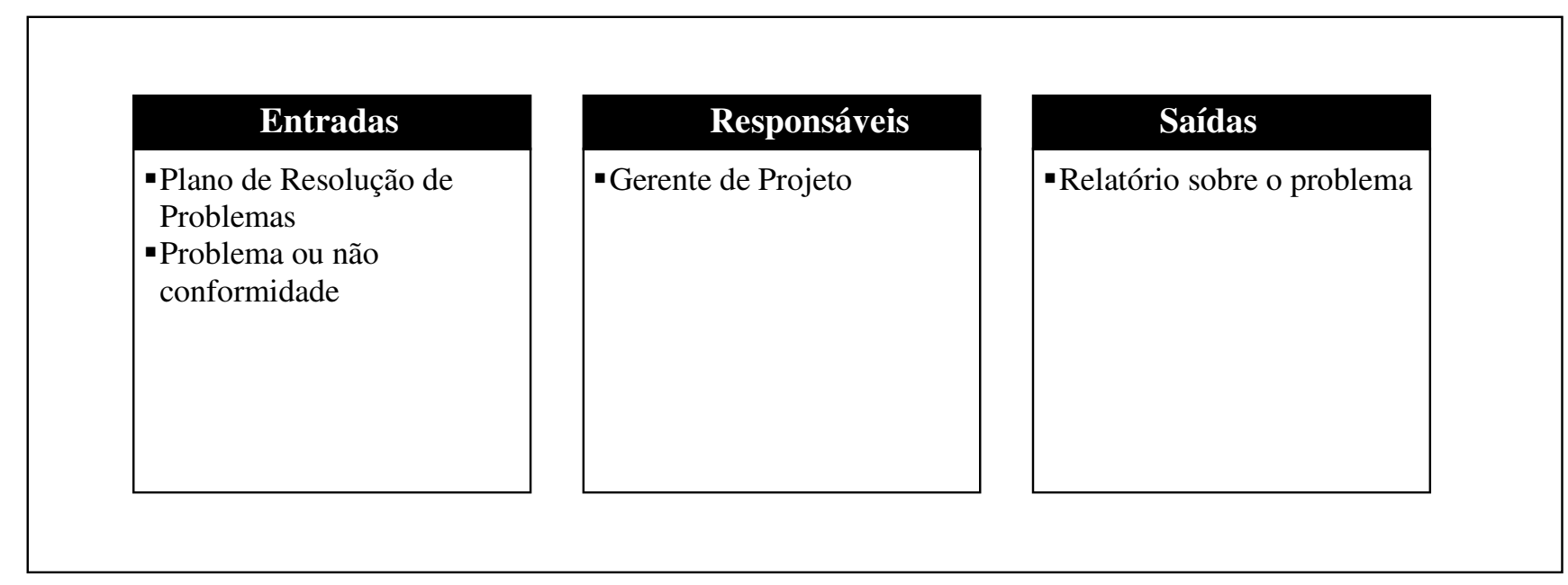

Figura 30: Resolução de Problemas: artefatos e responsáveis

Entradas para Resolução de Problemas:

- Plano de Resolução de Problema: de acordo com o plano, a atividade é executada.

- Problema e não conformidade: problema encontrado em alguma fase do projeto que não tenha sido resolvido dentro do próprio processo que o identificou.

Responsáveis:

- Gerente de Projeto: identifica o problema e define as ações a serem tomadas e os profissionais que serão envolvidos.

Saídas:

- Relatório sobre o problema: registrar o problema, sua causa, os riscos, quais produtos ou processos afetados e qual a solução tomada. 
O Quadro 20 apresenta as tarefas de Resolução de Problemas.

Qaudro 20: Tarefas de Resolução de Problemas

\begin{tabular}{|c|l|}
\hline Atividades & Resolução de Problemas \\
\hline Meta & Identificar, avaliar e resolver um problema. \\
\hline Tarefas & $\begin{array}{l}\text { 1. Analisar o problema para identificar os danos e riscos causados. } \\
\text { 2. Categorizar e priorizar a investigação do problema, de acordo com o } \\
\text { esquema definido. } \\
\text { 3. Investigar as causas do problema e avaliar quais produtos ou processos são } \\
\text { afetados. } \\
\text { Avaliar em qual camada (negócio, de conteúdo ou de fonte de dados) } \\
\text { da aplicação o processo é originado e verificar se propaga para outras } \\
\text { camadas. Verificar se o erro é de conteúdo, de navegabilidade, } \\
\text { funcionalidade, de projeto, ou seja, onde os requisitos não estão sendo } \\
\text { atendidos. } \\
\text { Se o problema for detectado com a aplicação já em uso, avaliar } \\
\text { questões legais e sociais sobre os danos causados. Avaliar riscos para } \\
\text { os usuários. }\end{array}$ \\
$\begin{array}{l}\text { 4. Planejar a solução do problema, avaliando custos, riscos de alterações e } \\
\text { impactos no projeto. } \\
\text { 5. Solucionar o problema ou não conformidade. } \\
\text { 6. Rever o planejamento do projeto. } \\
\text { 7. Gerar um relatório sobre o problema e ações tomadas e encaminhá-lo ao } \\
\text { responsável que o relatou. }\end{array}$ \\
\hline
\end{tabular}

\subsection{ACOMPANHAMENTO DE PROJETO}

Definição: tem o objetivo de acompanhar o projeto para fornecer visibilidade adequada do progresso das atividades para tomar medidas efetivas se não estiverem de acordo com os palnos estabelecidos.

O gerenciamento de projetos Web é complexo, pois envolve a gestão de equipe multifuncionais, o desenvolvimento de diversos produtos intermediários, concilia diversas 
fontes de necessidades, geralmente envolve terceirização, e principalmente muitas iterações com o cliente.

Por isso, o processo de acompanhamento é muito importante para obter controle global do projeto e, em caso de problemas, a mudança adequada da direção do projeto ou de um planejamento alternativo.

A Figura 31 apresenta as atividades do processo.

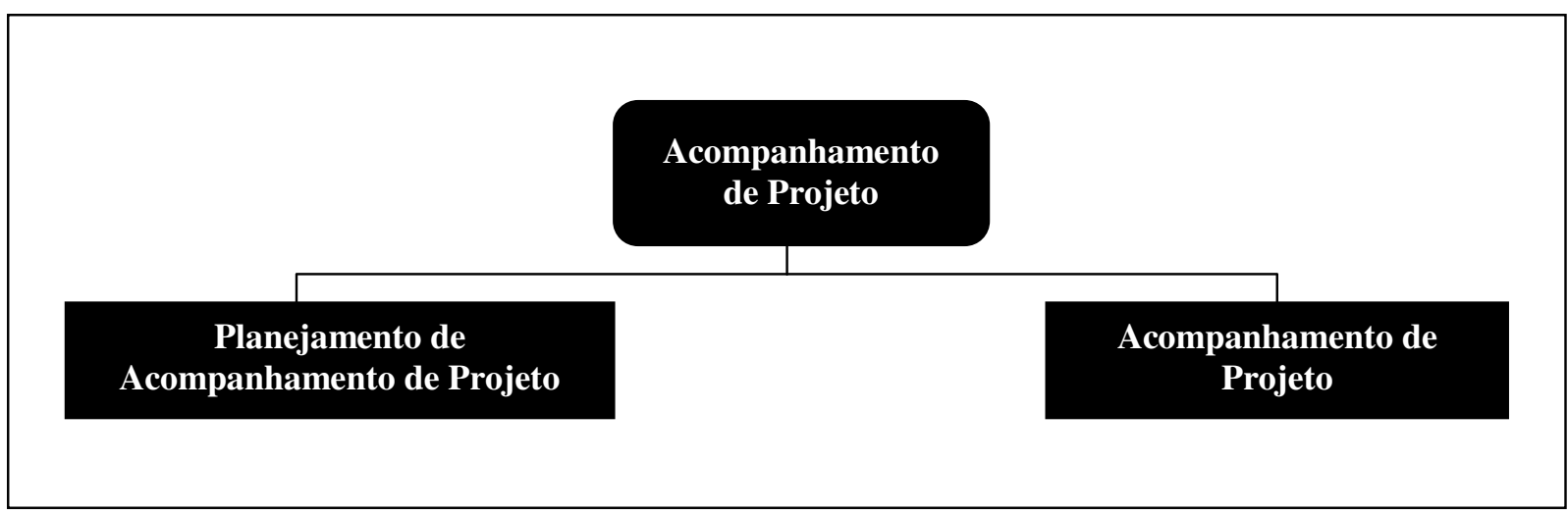

Figura 31: Atividades de Acompanhamento de Projeto

\section{Planejamento de Acompanhamento de Projeto}

Definição: tem o objetivo de estabelecer uma estrutura organizacional adequada para implementar o processo de Acompanhamento de Projeto.

A Figura 32 apresenta as entradas, responsáveis e saídas da atividade.
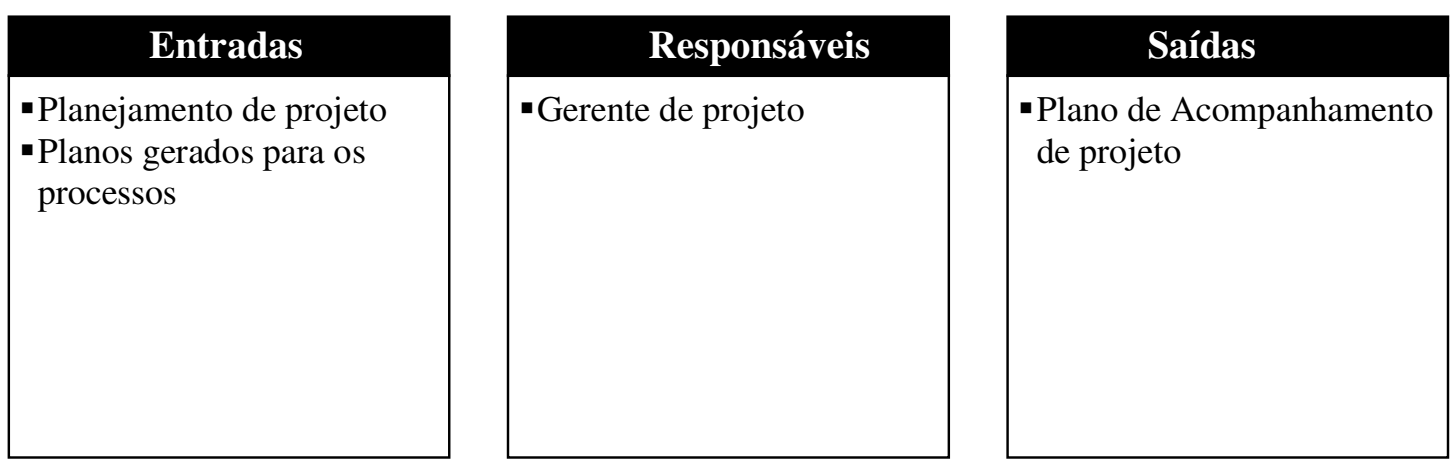

Figura 32: Planejamento de Acompanhamento de Projeto: artefatos e responsáveis 
Entradas para Planejamento de Acompanhamento de Projeto:

- Planejamento de projeto: é analisado para identificar as atividades adequadas para o acompanhamento de projeto e estabelecer responsabilidades e prazos para o acompanhamento.

- Planos gerados para os processos: os planos de processos, gerados nas atividades de planejamento de cada processo, são analisados para estabelecer atividades que devem ser checadas em relação a cumprimento de execução e prazos.

Responsáveis:

- Gerente de projeto: estabelece as tarefas, procedimentos, responsabilidades e prazos para o processo.

Saídas:

- Plano de acompanhamento de projeto: desenvolvido para conduzir as atividades e tarefas envolvidas no processo. Descreve responsabilidades, procedimentos e recursos necessários para implementar o processo.

O Quadro 21 apresenta as tarefas da atividade.

Quadro 21: Tarefas de Planejamento de Acompanhamento de Projeto

\begin{tabular}{|c|l|l|}
\hline Atividades & Planejamento de Acompanhamento de Projeto & \\
\hline Meta & $\begin{array}{l}\text { Gerar um plano para a implementação e execução do processo de } \\
\text { Acompanhamento de Projeto. }\end{array}$ \\
\hline \multirow{5}{*}{ Tarefas } & $\begin{array}{l}\text { 1.Analisar os planos dos processos e planejamento de projeto para estabelecer } \\
\text { as tarefas iniciais do processo. } \\
\text { 2.Definir responsabilidades, procedimentos e ferramentas para o } \\
\text { implementação e execução do processo. } \\
\text { 3.Estabelecer a periodicidade de reuniões com o cliente. } \\
\text { 4.Estabelecer a periodicidade de reuniões de acompanhamento de projeto com } \\
\text { a equipe de desenvolvimento e outros que afetam o projeto. } \\
\text { 5.Estabelecer produtos e marcos no projeto para revisão. } \\
\text { 6. Com as definições acima, gerar um plano de acompanhamento de projeto. }\end{array}$ \\
\hline
\end{tabular}




\section{Acompanhamento de Projeto}

Definição: realiza o acompanhamento de projeto, verificando atividades e produtos se estão no prazo e de acordo com o estabelecido.

A Figura 33 apresenta as entradas, responsáveis e saídas da atividade.

\section{Entradas}

- Plano de Acompanhamento de projeto.

- Planejamento de projeto

\section{Responsáveis}

- Gerente de projeto.

\section{Saídas}

- Relato da situação do projeto.

- Novo planejamento de projeto (se necessário).

Figura 33: Acompanhamento de Projeto: artefatos e responsáveis

Entradas para Acompanhamento de Projeto:

- Plano de Acompanhamento: o acompanhamento é realizado de acordo com o estabelecido no plano.

- Planejamento de projeto: as atividades, recursos e prazos do planejamento de projeto são controlados para alcançar os resultados esperados.

Responsáveis:

- Gerente de projeto: realiza o acompanhamento de projeto avaliando atividade, produtos, pessoas e outros recursos.

Saídas:

- Relato da situação do projeto: informe sobre o progresso das atividades e a adequação dos produtos aos requisitos.

- Novo planejamento de projeto: no caso de problemas ou mudanças no projeto, um novo planejamento de projeto é criado.

O Quadro apresenta as tarefas da atividade. 
Quadro 22: Tarefas de Acompanhamento de Projeto

\begin{tabular}{|c|c|}
\hline Atividades & Planejamento de Acompanhamento de Projeto \\
\hline Meta & $\begin{array}{l}\text { Controlar o projeto para identificar problemas no progresso das atividades e } \\
\text { produtos. }\end{array}$ \\
\hline Tarefas & $\begin{array}{l}\text { 1.Realizar reuniões periódicas com a equipe, cliente e envolvidos no projeto } \\
\text { para determinar a situação do projeto, identificar problemas e alterações. } \\
\text { 2. Avaliar se o progresso das atividades está de acordo com os prazos } \\
\text { estabelecidos. } \\
\text { 3. Avaliar se os recursos estão de acordo com as habilidades necessárias e } \\
\text { alocados adequadamente. } \\
\text { 4.Avaliar questões de risco no projeto. } \\
\text { 5. A cada ciclo de desenvolvimento validar os requisitos do projeto. } \\
\text { Como o desenvolvimento de aplicações Web segue um modelo } \\
\text { interativo e incremental, a cada ciclo é necessário validar os requisitos } \\
\text { que foram levantados e não executados no ciclo anterior, pois com a } \\
\text { evolução da aplicação, os requisitos mudam e os anteriores podem não } \\
\text { mais serem necessários. } \\
\text { 6. Identificar a necessidade alterações no planejamento de projeto. }\end{array}$ \\
\hline
\end{tabular}

\section{1 CONSIDERAÇÕES FINAIS}

Neste capítulo foram apresentados os Processos de Apoio propostos no trabalho. Os Processos foram baseados nos Processos da Norma ISO/IEC 12207.

Para verificar a aplicabilidade dos Processos propostos, no próximo capítulo é apresentado um estudo de caso. 


\section{CAPÍTULO 5: APLICABILIDADE dOS Processos de APOIO}

\section{1 CONSIDERAÇÕES INICIAIS}

Neste capítulo, é apresentado o estudo de caso conduzido para a verificação da aplicabilidade dos Processos de Apoio definidos no trabalho.

Para tanto, escolheu-se uma empresa de pequeno porte, com cerca de 30 funcionários, desenvolvedora de software com projetos Web para clientes com variados tipos de negócios. A empresa demonstrou bastante interesse no estudo, pois estava engajada na definição e melhoria de seus processos de desenvolvimento de aplicações Web, principalmente os de Apoio.

Ressalta-se que o principal objetivo do Estudo de Caso é verificar a adequação dos processos ao desenvolvimento das aplicações Web, ou seja, se podem ser utilizados num ambiente real e se servem como guia para a definição de melhores processos de apoio ao desenvolvimento das aplicações. Não é o intuito fazer uma avaliação completa com medições, comparações com outros processos de mesma natureza ou avaliações de performance e produtividade. 


\subsection{ESTUDO DE CASO}

O objetivo do estudo de caso é verificar se os Processos de Apoio propostos, baseados em conceitos teóricos, poderiam ser aplicados numa situação prática e se, realmente, dariam apoio ao desenvolvimento de aplicações Web num ambiente real de uma pequena empresa para alcançar produtos com qualidade.

Sendo assim, os processos foram utilizados na empresa escolhida durante o desenvolvimento de uma das funcionalidades de um grande projeto.

A seguir, são descritos os passos que foram necessários na condução do estudo de caso:

Passo 1: Empresa. Escolher a empresa para o estudo de caso.

Passo 2: Metodologia da Empresa. Entrevistas informais com os diretores da empresa, para conhecer a organização, entender o negócio, sua metodologia e papéis de desenvolvimento.

Passo 3: Projeto. Escolher um projeto a ser desenvolvido que possuísse as características necessárias para que os Processos de Apoio definidos pudessem ser utilizados e verificados.

Passo 4: Processos de Apoio. Apresentar para os integrantes da equipe de desenvolvimento do projeto os Processos de Apoio definidos e aplicá-los no projeto.

Passo 5: Análise dos Processos de Apoio. Entrevistar, informalmente, os envolvidos com o estudo de caso, para colher depoimentos sobre os Processos de Apoio propostos. 


\subsubsection{A EMPRESA}

A empresa na qual foi feito o estudo de caso é a Lúcida. A Lúcida é uma provedora de solução em Web, oferecendo experiência e conhecimento no uso operacional, gerencial e estratégico da Internet como ferramenta de negócios e relacionamento. Possui equipe para atuar desde a concepção estratégica do produto até a sua contínua evolução.

Localizada na cidade de São Paulo, a empresa apresenta relacionamentos comerciais com clientes nacionais e internacionais de diversos tipos de negócios: telecomunicação (telefonia fixa e de celular), segmento de cosméticos, de gêneros alimentícios, uma rede de hotéis, portal de conteúdo de Web, uma grande indústria nacional de celulose e papel, entre outras.

A Lúcida é dividida em quatro unidades de negócio independentes e especializadas. Essas unidades atuam através de um processo metodológico, adaptado às necessidades de cada projeto.

As unidades de negócio da empresa são:

Grupo Lúcida: possui a capacidade gerencial e estratégica para garantir o sucesso de projetos de Internet.

$>$ Lúcida Studio: trata-se da agência interativa do grupo, com capacidades de comunicação digital, marketing de relacionamento e identidade visual de aplicações Web.

Lúcida Tecnologia: unidade focada no conhecimento tecnológico das soluções Web. Possui especialistas em Web Services, Java,Net, bancos de dados, infraestrutura e integração de sistemas.

$>$ Lúcida Software: produz produtos, soluções e componentes de negócio para acelerar e otimizar projetos de Internet.

\subsubsection{METODOLOGIA DA EMPRESA}

Apesar dos Processos de Apoio definidos serem independentes do modelo de desenvolvimento utilizado pela empresa, é necessário conhecer a metodologia empregada 
para que os Processos de Apoio sejam aplicados de forma consistente e adequados à realidade da empresa e para que quaisquer influências de outros processos possam ser analisadas.

A metodologia utilizada pela Lúcida para desenvolvimento de projetos é resultado de análises e customizações de algumas metodologias e frameworks de processo existentes, entre eles: CMM, PMI, Agile Alliance, RUP e UML.

Existem três grupos principais para classificação de qualquer atividade realizada ao longo dos processos que compõem a metodologia: Studio, Tecnologia e Gerência.

O grupo Studio compreende as atividades relacionadas à: usabilidade, arquitetura de informação, marketing de relacionamento, criação, arte, redação e desenvolvimento de interfaces.

$>\mathrm{O}$ grupo Tecnologia compreende as atividades relacionadas ao desenvolvimento de software em geral, incluindo: requisitos, análise, projeto, codificação, testes e deployment (entrega e implantação).

O grupo Gerência compreende as atividades relacionadas à gerência de projetos e de outras áreas gerenciais referenciadas: gerenciamento de escopo, gerenciamento de prazos, gerenciamento de custo, gerenciamento de recursos e gerenciamento de subcontratação.

O que orienta a forma como a metodologia está estruturada é a existência dos ciclos de desenvolvimento. Cada ciclo de desenvolvimento é composto de iterações, cada iteração contempla um conjunto de requisitos e produz como resultado um sistema pronto para aplicação.

Antes do início de cada iteração do projeto, o planejamento feito no início da iteração anterior é avaliado. Com base nos resultados desta avaliação é feito o (re)planejamento da iteração atual e o planejamento da próxima iteração.

A metodologia é subdividia em dois grupos: 
O subconjunto da metodologia, utilizada pelo grupo Studio, é chamado de CDD (Content-Driven Development), no qual os conteúdos do projeto direcionam a execução das tarefas.

$>$ O subconjunto da metodologia, utilizada pelo grupo Tecnologia, é chamado de FDD (Feature-Driven Development), onde as funcionalidades direcionam a execução das tarefas.

Os papéis mapeados e utilizados nos processos que compõem a metodologia da Lúcida são:

- Arquiteto de Informação;

- Arquiteto de Interface;

- Arquiteto de Software;

- Desenvolvedor de Interface;

- Desenvolvedor de Tecnologia de Informação;

- Diretor de Arte;

- Diretor de Criação;

- Diretoria de Projeto;

- Engenheiro de Infraestrutura;

- Gerente de Negócios;

- Gerente de Projetos;

- Gerente de Qualidade;

- Gerente de Relacionamento;

- Redator;

\subsubsection{PROJETO}

O estudo de caso foi realizado em um projeto, no qual o cliente era uma das maiores empresas mundiais de Consultoria de Recuros Humanos (RH) e que necessitava da automatização de várias funções de um dos seus departamentos.

Para determinar a escolha do projeto, os seguintes requisitos foram respeitados: 
O produto final é uma aplicação Web;

Todos os processos de apoio definidos poderiam ser utilizados durante o ciclo de desenvolvimento do projeto;

Disponibilidade da equipe de desenvolvimento para utilizar os processos, o que envolvia treinamento e entrevistas de acompanhamento;

A aplicação dos processos e a divulgação estavam de acordo com as políticas de segurança de informação da empresa;

O prazo previsto para o projeto foi estimado em 12 meses, o que envolvia o desenvolvimento de cerca de 20 funcionalidades. Porém, o estudo de caso foi aplicado, somente, em uma delas com duração de 2 meses.

A funcionalidade, na qual o estudo de caso foi aplicado, deveria permitir a entrada de informações através de questionários na Web. Esses questionários seriam respondidos, remotamente, por funcionários da própria empresa de Consultoria de $\mathrm{RH}$ e dos funcionários das empresas clientes dessa consultoria. Os questionários são pesquisas que a Consultoria realiza para posicionar as suas empresas clientes no mercado, em relação a dois assuntos: cargos e salários, políticas e benefícios dos funcionários.

Os questionários deveriam ser fáceis de responder e impedir erros por parte do usuário, e por isso possuíam diversas regras de validação, que conduziam as respostas de forma consistente. Além das validações de campos de moeda, intervalos de valores, campos alfanuméricos válidos, dependências entre perguntas e dependências entre questionários.

As perguntas dos questionários deveriam ser organizadas e apresentadas nas páginas da aplicação de maneira clara e concisa. Muitas perguntas eram relacionadas umas com as outras e só apareciam nos questionários de acordo com a resposta de perguntas anteriores. Isso, implicou num grande esforço para garantir qualidade de apresentação de conteúdo.

Para melhor contextualização, a Figura 34 ilustra o Modelo de Dados criado para a funcionalidade dos Questionários. 


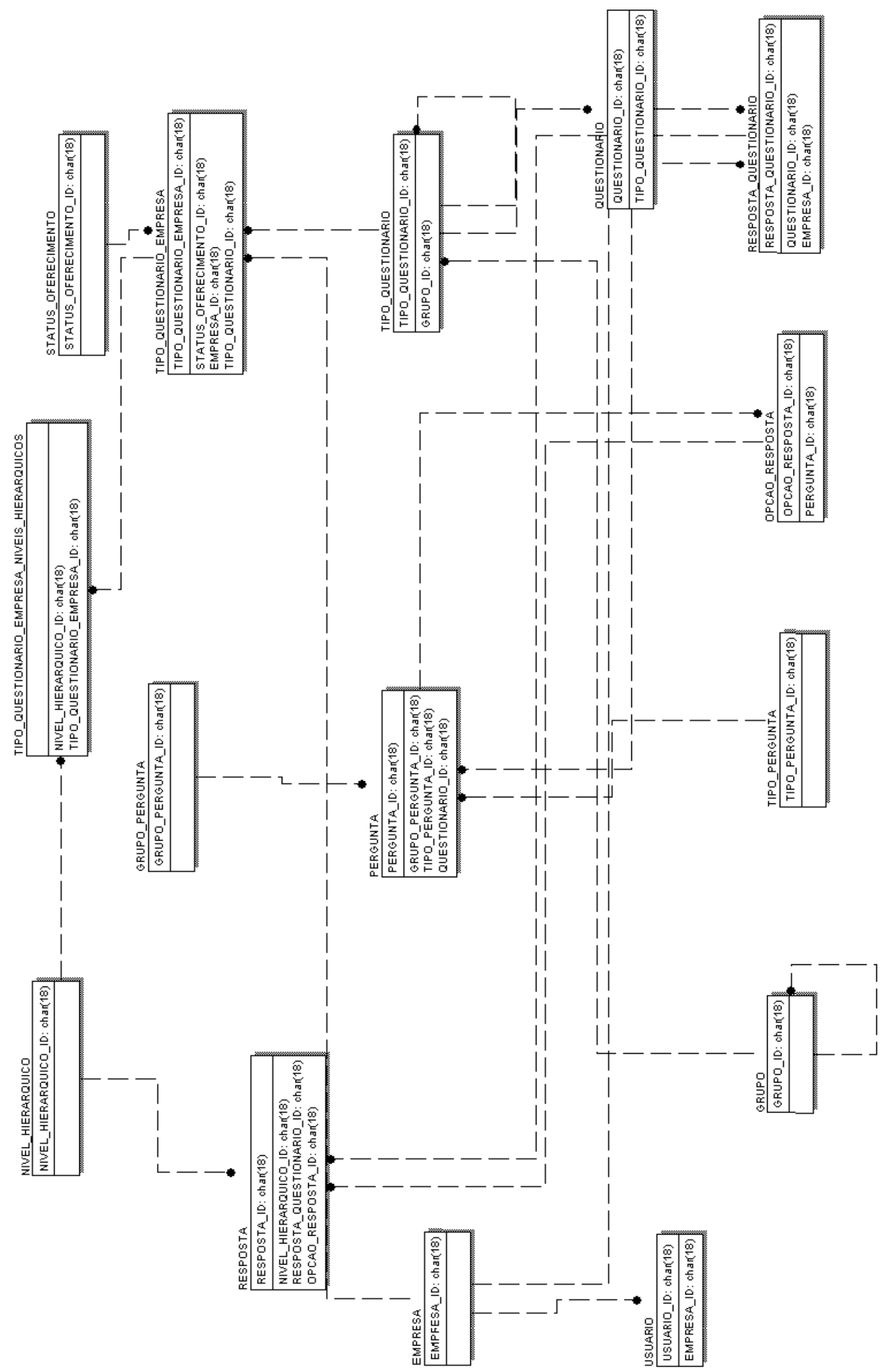

Figura 34: Modelo de Dados da Funcionalidade Questionário. 


\subsubsection{PROCESSOS DE APOIO}

No início do estudo de caso, foram realizadas duas palestras explicando os conceitos gerais da Norma ISO/IEC12207 para todos os funcionários. Para não prejudicar o andamento dos projetos da empresa, as palestras foram realizadas em dias não consecutivos na semana, dividindo os funcionários em dois grupos.

Também foram feitas entrevistas informais com os gerentes de projeto da empresa para conhecer quais processos ou atividades de apoio já eram realizadas. Isso foi importante para situar o conhecimento dos funcionários em relação aos conceitos propostos no estudo. Não havia o intuito em relatar e comparar as atividades já aplicadas e as novas propostas, uma vez que a avaliação de processos é complexa e não era esse o objetivo. A Empresa já aplicava algumas atividades de apoio, porém essas atividades não eram agrupadas num processo definido e documentado, assim como, não eram claras as responsabilidades de cada papel na execução dessas atividades.

As atividades de apoio já realizadas estavam relacionadas com os processos de: Validação, testes de funcionalidade, de integração de arquiteturas, de navegação e de conteúdo; Documentação, haviam alguns exemplos de documentos que eram seguidos pela equipe: contrato, propostas de projeto, mapa de relacionamento entre as páginas, modelo de dados, termos de aceite e WBS (work breakdown structure ou estrutura hieráquica do trabalho); e Usabilidade, arquitetura da informação, projeto das páginas, implementação estática das páginas, testes e atividades de aprovação de interfaces.

Após a escolha do projeto, durante a fase de planejamento desse projeto e tendo definido os integrantes da equipe, foram apresentados os conceitos referentes aos Processos de Apoio propostos. Essa etapa, serviu para alinhar o conhecimento de todos aqueles que seriam envolvidos e para concientizá-los da importância de Processos de Apoio no desenvolvimento de aplicações Web.

Para a realização dos Processos de Apoio propostos, o gerente do projeto, em reuniões diárias com a equipe, definia as atividades de apoio que seriam executadas em cada fase do 
projeto. Nessas reuniões diárias, também era questionado se as atividades estavam sendo realizadas e se havia algum problema identificado.

De maneira geral todas as atividades foram realizadas, porém não foram gerados os planos de planejamento de cada processo formalmente e foram criados alguns relatórios sobre a execução das atividades. Isso porque não houve tempo hábil para a documentação durante o desenvolvimento do projeto e também o objetivo do estudo de caso era verificar a aplicabilidade dos processos, como dito, não havia intuito de medições formais. Portanto, as atividades foram seguidas como diretrizes e foram checadas informalmente pelo gerente.

\subsubsection{CONCLUSÃO DO ESTUdO DE CASO}

A realização do Estudo de Caso foi importante para verificar a aplicabilidade dos Processos de Apoio propostos no trabalho, num ambiente real de uma pequena empresa.

A seguir, são apresentados os pontos fortes e pontos fracos sugeridos pela empresa sobre aos Processos propostos. Ressalta-se que a determinação desses pontos, está relacionada com a experiência dos profissionais tanto com os processos, quanto com a capacidade de avaliação dos mesmos.

Pontos Fortes:

-Os processos estão organizados de forma clara e concisa, fácil de entender e seguir;

- As atividades dos processos cobrem as etapas principais e importantes para apoio ao desenvolvimento de projeto de aplicações Web;

- Os processos ajudam a definir papéis e responsabilidades;

-Os processos tornaram claros os objetivos a serem alcançados nas suas execuções e quais as atividades necessárias;

- Os processos de Usabilidade, Validação e Acompanhamento de Projeto foram essenciais para o projeto;

-São um guia importante, principalmente, para as empresas que estão iniciando a definição de seus processos; 
- Foi observado uma melhoria na documentação das etapas do projeto do estudo de caso, comparado com outros projetos que não participaram do estudo;

\section{Pontos Fracos}

-Em algumas atividades, deveria apresentar mais detalhes, ou seja, aprofundar os processos mais especificamente para os projetos Web. Principalmente para os processos de Gerenciamento de Configuração, Resolução de Problemas e Documentação.

- O processo de Gerenciamento de Configuração foi considerado complexo.

- Os conceitos sobre os processos de Verificação e Validação deveriam ser exemplificados, pois os dois são os que causam mais dúvidas, pois são entendidos como se fossem os mesmos.

-Não apresenta os relacionamentos, diretamente, com os outros processos de desenvolvimento envolvidos no projeto;

-Poderia sugerir ferramentas importantes para serem utilizadas durante os processos e no seu acompanhamento;

-Falta de métricas de validação dos processos;

-Não utiliza outras referências importantes de mercado como base para o trabalho.

\subsection{CONSIDERAÇÕES FINAIS}

Neste capítulo, foram apresentados os resultados obtidos com o estudo de caso, que pretendia verificar se o que foi definido exclusivamente sobre uma base teórica, conteria as condições para ser utilizado em uma situação prática. 
Alguns dos conceitos e das noções exigidas já estavam claros para os profissionais que participaram do projeto, o que contribuiu tanto para a utilização dos processos como para a avaliação dos mesmos. Os profissionais mostraram-se comprometidos e engajados para assimilarem novos conceitos que pudessem melhorar suas atividades. A empresa estava empenhada em melhorar seus processos de desenvolvimento, e os Processos de Apoio seriam parte integrante dessa melhoria.

O estudo demonstrou que os Processos de Apoio propostos contribuem com a melhoria do desenvolvimento de aplicações Web, apesar de que alguns pontos devem ser aperfeiçoados e revistos. Portanto, os Processos de Apoio propostos podem auxiliar as pequenas empresas a alcançar produtos com qualidade. 


\section{CAPÍTUlo 6: Conclusões E TRABALHOS FUTUROS}

\section{1 CONCLUSÕES}

A complexidade das aplicações Web tem crescido consideravelmente. No inicio concebidas para simples tarefas, tornaram-se um meio para criar sistemas complexos e críticos. Aplicações de comércio eletrônico, aplicações científicas ou médicas, são alguns exemplos.

A relevância econômica das aplicações Web aumenta, significativamente, a pressão pela entrega de resultados rápidos. Com isso, os princípios de Engenharia de Software são normalmente negligenciados pelos desenvolvedores de aplicações Web que, geralmente, utilizam técnicas similares àquelas $a d$ hoc usadas pelos seus predecessores nos anos sessenta e setenta, resultando em sistemas de baixa qualidade. Como consequência, está crescendo a demanda por metodologias e ferramentas de garantia de qualidade de aplicações Web. Os profissionais desta área de conhecimento estão reconhecendo a necessidade em adaptar princípios da Engenharia de Software para apoiar o desenvolvimento dessas aplicações.

Dessa forma, neste trabalho, foram desenvolvidos processos para serem utilizados na produção de aplicação Web, adaptados à sua natureza evolutiva. Os processos propostos são 
de apoio ao desenvolvimento dessas aplicações, criando meios para auxiliar os profissionais a definir seus papéis e proporcionar às organizações melhores entendimentos das atividades envolvidas. Os processos propostos que integram pessoas, tarefas e métodos provem a base para garantir a qualidade da aplicação final.

Em relação ao desenvolvimento dos processos propostos, vale ressaltar que, sendo baseados no princípio da evolução, devem ser assim, entendidos como a primeira versão de uma abordagem para apoiar a produção de aplicações Web, por uma organização de pequeno porte. Sendo assim, os processos podem e devem ser melhorados, já que dependendo dos projetos e da organização produtora da aplicação, esses devem ser adaptados de acordo com as suas necessidades. Além do que, os processos propostos não englobam todas as tarefas ou atividades e papéis que são necessários para garantir total cobertura de apoio ao desenvolvimento das aplicações Web, apesar do esforço empreendido neste trabalho, visto que, como ressaltado, é uma versão inicial.

O primeiro passo em direção às melhorias dos Processos de Apoio propostos foi a realização de um estudo de caso. O estudo de caso tinha como objetivo primordial verificar se os processos, baseados em conceitos teóricos, poderiam ser aplicados num ambiente real de uma pequena empresa.

Com o estudo de caso, concluiu-se que as atividades dos processos propostos cobrem as etapas principais e primordiais para o apoio ao desenvolvimento de projetos de aplicações Web, provando ser aplicável em uma situação prática. Porém, há falhas que devem ser corrigidas. Os processos de Gerenciamento de Configuração, Documentação e Resolução de Problemas deveriam conter mais tarefas específicas para os projetos Web, os processos de Validação e Verificação deveriam ter sido melhor exemplificados e faltaram sugestões de ferramentas e métricas para cada processo.

De maneira geral, os processos de apoio propostos auxiliam, como parte integrante de melhorias contínuas, as pequenas empresas na definição de papéis e responsabilidades, de tarefas e atividades e na criação de uma estrutura organizacional para alcançar produtos Web com qualidade. 


\subsection{TRABALHOS Futuros}

Para a melhoria dos processos de apoio desenvolvidos neste trabalho, é sugerida a continuação de pesquisas relacionadas com a qualidade desses processos, através dos seguintes trabalhos:

$>$ Os processos propostos não apresentam nenhuma métrica para medição dos processos. Durante o estudo de caso, a única métrica utilizada foi o tempo gasto em cada planejamento e execução das atividades, para controle da empresa. Porém, para a avaliação e melhoria de processos são necessárias métricas consistentes e que forneçam resultados para validar se a meta de cada atividade foi alcançada.

Existem diversas ferramentas para auxiliar a construção de aplicações Web. Essas ferramentas poderiam ser divididas em categorias de acordo com os seus objetivos. E mesmo entre as ferramentas de mesma categoria, há diferenças entre elas. Um trabalho sugerido, então, seria a descrição, análise do uso e benefícios que cada ferramenta poderia trazer para o desenvolvimento das aplicações Web.

Os processos de apoio propostos poderiam ser estruturados para abranger processos de apoio ao desenvolvimento de aplicações Web baseados em outras referências como, por exemplo, CMM [Paulk et al, 1995] e ISO 15504 [ISO 15504, 1998].

$>$ O trabalho poderia ser estendido para abranger a adaptação dos outros processos definidos na Norma ISO/IEC 12207 - processos fundamentais, processos organizacionais e de adaptação - para a realidade de projetos Web.

Modelos de melhoria contínua e avaliação dos processos de desenvolvimento de aplicações Web poderiam ser sugeridos, adaptados às situações desse tipo de aplicação. Esses modelos poderiam ser baseados naqueles já consagrados pela Engenharia de Software, como CAF (CMM) e Parte 8 da ISO 15504 para avaliação dos processos, e IDEAL (CMM) e Parte 7 da ISO 15504 para a melhoria. 


\section{REFERÊNCIAS BIBLIOGRÁFICAS}

[Becker \& Berkemeyer, 2002] Becker,S.A.;Berkemeyer,A. Rapid application design and testing of Web usability. Multimedia, IEEE , Volume: 9 , Issue: 4 , Oct.-Dec. 2002 Pages:38 - 46

[Berlack,1992] Berlack, H. R. Software Configuration Management. $1^{\circ}$ Edição. Nova York. John Wiley \& Sons, 1992.

[Bersoff,1979] Bersoff, E. H.; Henderson, V.D. e Siegel, S.G. Software Configuration Management: A tutorial. Los Alamos, Califórnia. IEEE Computer. Volume:12, n.1, 1979.

[Bevan, 1997] Bevan, N. Usability issues in Web site design. Proceedings of HCI'97. 1997.

[Borges, 1996] Borges, C.B; Morales, I; Rodriguez, N.J; Guidelines for designing usable World Wide Web pages. 1996.

[Buckley,1993] Buckley, F.J. Implementing a Software Configuration Management Enviroment. Los Alamos, California, IEEE Computer Society, v.27, n.2, 1993.

[Chaubey \& Suresh, 2001] Chaubey, Rahul; Suresh, J.K. Integration vs Development: an Engineering Approach to Building Web Applications. Proceedings 2001. Austrália 2001. Páginas 171-181. 
[Coda et al, 1998] Coda, F.; Ghezzi, C.; Vigna, G.; Garzotto, F.; Towards a software engineering approach to Web site development Software Specification and Design, 1998. Proceedings. Ninth International Workshop on , 16-18 April 1998.

[Constantine \& Lockwood,1999] L. Constantine and L.Lockwood. Software for Use: A Practical Guide to the Models and Methods of Usage-Centered Design, Addison Wesley Longman. Reading, Mass.1999.

[Deshpande \& Hansen, 2001] Deshpande Y.; Hansen, S. Web Engineering: Creating a Discipline among Disciplines. IEEE Multimidia. Volume: 8. Issue: 2. Abril-Junho 2001. Páginas: 82-87.

[Fayad \& Cline] Fayad, M; Cline M.P. Aspects of Software Adaptability. Comunications of the ACM. Outubro 1996. Páginas: 58-59

[Fraternali, 1999] Piero Fraternali, Tools and Approaches for Data Intensive Web Application Development: a Survey, in ACM Computing Surveys 31[3]; 227-263 1999.

[Fuggetta, 2000] Fuggetta, A. Software Process: a Rodmap. In: The Future of Software Engineering. A. Finkelstein [ed], 2000.

[Ghezzi, 1997] Ghezzi,C. Software engineering issues for network computing Software Maintenance, 1997. Proceedings., International Conference on, 1-3Oct.1997 Pages:2 - 2.

[Gilder, 1998] Gilder George, The Knowledge Enterprise and the New World of Techology, Keynote address, Knowledge Inc.'s Annual Strategic Forum on Knowledge, Profit and Potencial, theme: Capitalizing on Knowledge, Oct 26,1998.

[Ginige, 2002] Ginige, A.; Web Engineering: Managing the Complexity of Web Systems Developement. IEEE Multimidia. Volume: 8. Issue: 1. Jan-Mar 2001. Páginas: 14-18. 
[Ginige \& Murugesan, 2001a] Ginige, A.; Murugesan, S. Web Engineering: An Introduction. IEEE Multimidia. Volume: 8. Issue: 1. Jan-Mar 2001. Páginas: 1418.

[Ginige \& Murugesan, 2001b] Ginige, A.; Murugesan, S. The Essence of Web Engineering. IEEE Multimidia. Volume: 8. Issue: 2. Abril-Junho 2001. Páginas: 22-25.

[Ginige et al, 1998] Ginige et al. WebE [Web Engineering] http://aeims.uws.edu.au/WebEhome/

[Hansen, 1999] Hansen, S., Deshpande; Y.; Murugesan, S. A Skills Hierarchy for Web Information System Development. Proc. First ICSE Workshop on Web Engineering. ACM. Los Angeles. Maio de 1999.

[Holck, 2003] Holck, J. 4 Perspectives on Web Information Systems. 36th HICSS Hawaii International Conference on System Sciences. 2003.

[IEEE/EIA 12207.0,1996] IEEE/EIA 12207.0-1996. Industry Implementation of International standard ISO/IEC 12207: 1995.

[IEEE Std 828,1998] IEEE for Software Configuration Management Plans. 1998

[IEEE Std 730,2002] IEEE Standard for Software Quality Assurance Plans. 2002

[IEEE Std 1028, 1988] IEEE Standard for Software Reviews and Audits. 1988.

[ISO 8402, 1994] ISO 8402, Quality Management and Quality Assurance_Vocabulary, Int'1 Org. for Standardization, 1994.

[ISO/IEC 9126, 1991] ISO/IEC 9126. Information Technology - Software Product Evaluation - Quality Characteristics and Guidelines for their use.. International Standard Organization. 1991.

[ISO/IEC 12207, 1995] ISO/IEC 12207. Information Technology - Software Life Cycle Process. International Standard Organization. 1995. 
[ISO/IEC 13407, 1999] ISO 13407: Human-centred design processes for interactive systems. 1999.

[ISO/IEC TR 15504] ISO/IEC TR 15504 International standard for Software Process Assessment. 1998.

[Jokela, 2002] Jokela, T., Assesment of Usability Engineering Process: Experiences from Experiments. Proceedings of the 36th Hawaii International Conference on System Sciences [HICSS'03]. 2002.

[Juristo et al, 2001] Juristo, N.;Windl, H.; Constantine,L.; Introducing usability Software, IEEE, Volume: 18 , Issue: 1, Jan.-Feb.2001 Pages:20 - 21.

[Lee, 2002] Kar Tin Lee. Designing enhanced learning environments on the web - the challenge.Computers. in Education, 2002. Proceedings. International Conference on , 3-6Dec.2002 Pages:1534 - 1535 vol.2.

[Li et al, 2000] Li Hongsheng; Shi Tielin; Yang Shuzi. An approach of sampling computing for wavelet analysis and its Web-based implementation. Signal Processing Proceedings, 2000. WCCC-ICSP 2000. 5th International Conference on, 21-25 Aug.2000 Pages:395 - 398 vol.1.

[Lima et al, 2000] Lima R et al. Evaluation Web sites for an educational environment target for cardiology. Madri, Espanha, Fesma 2000.

[Lynch, 1999] Lynch, M; Watt, J.H.. Using the Internet for audience and customer research. Professional Communication Conference, 1999. IPCC 99. Communication Jazz: Improvising the New International Communication Culture. Proceedings. 1999 IEEE International, 7-10Sept.1999 Pages:121 - 130

[Lowe, 1999] Lowe, D. Web site evaluation. WebNet Journal . Outubro 1999. 
[Maldonado, 1991] Maldonado, J. C. Critérios Potenciais - Usos: Uma Contribuição ao Teste Estrutural de Software. Campinas, SP, Tese de doutorado, DCA/FEE/UNICAMP, Jul. 1991.

[Marugesan \& Deshpande, 2002] Marugesan, S.; Deshpande, Y. Meeting the Challenges of Web Application Developement: The Web Engineering Approach. ICSC'02. Orlando, Flórida. Maio de 2002.

[Mich et al, 2003] Mich, L.; Franch, M.; Gaio, Evaluating and designing Web site quality; Multimedia,IEEE, Volume:10, Issue:1, Jan.-March2003 Pages:34 - 43

[Nielsen, 1995]. Nielsen,J. Applying discount usability engineering.;Software, IEEE .Volume:12, Issue:1, Jan.1995 Pages:98 - 100.

[Offutt, 2002] Offutt, J. Quality Attributes of Web. Software Applications. IEEE Software. Volume: 19. Issue: 2. Março-Abril 2002. Páginas: 25-32.

[Olsina,1999] Olsina, L ; Rossi,L; Toward web-site quantitative evaluation: defining quality characteristics and attributes. WebNet99. 1999.

[Paulk et al, 1995] Paulk, C. et al The capability maturity model : guidelines for improving the software process . Reading, Mass. : Addison-Wesley Pub. Co., c1995.

[Phoha, 1997] Phoha, V.A. Standard for Software Documentation. Los Alamos, California, IEEE Computer Society, v.30, n.10, 1997.

[Pfleeger, 1998] Pfleger, S.L. Software Engineering - Theory and Practice. Nova Jersey, Prentice-Hall Inc., 1998.

[Powell, 1998] Powell, T. A. Web Site Engineering. Prentice-Hall. 1998.

[Pressman, 2002] Pressman, R. S. Engenharia de Software. Mc Graw Hill. 5a. Edição. 2002.

[Rocha et al, 2001] Rocha, A R. et al . Qualidade de Software. Teoria e Prática. Prentice Hall. $1^{\text {a }}$. edição. 2001. 
[Schneiderman,1993] B. Scheiderman, Designing the User interface: Strategies for Effective Human-Computer Interaction. Addison Wesley Longman, Reading, Mass. 1998.

[Uden, 2002] Uden, Lorna. Design Process for Web Applications. IEEE Multimidia. Volume: 9. Issue: 4. Outubro-dezembro 2002. Páginas: 47-55. 